
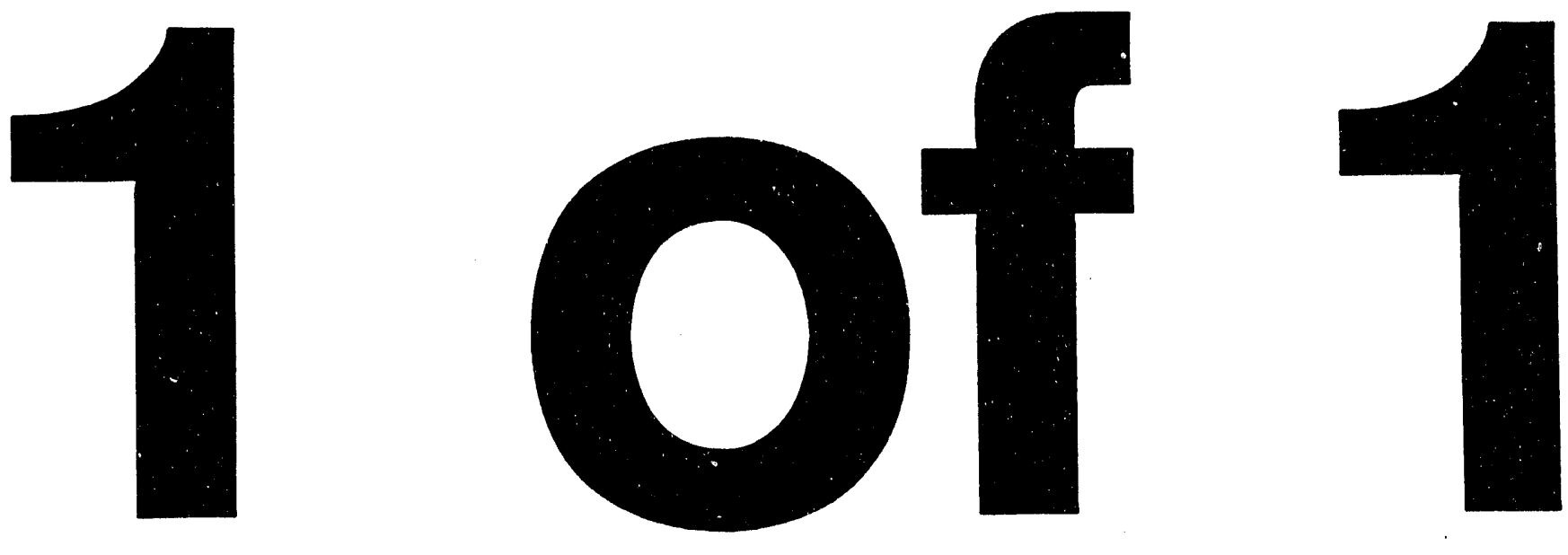


\section{Advanced Coal-Fueled Industrial Cogeneration Gas Turbine System Particle Removal System Development}

\section{Topical Report}

Michael Stephenson

March 1994

Work Performed Under Contract No.: DE-AC21-86MC23166

For

U.S. Department of Energy

Office of Fossil Energy

Morgantown Energy Technology Center

Morgantown, West Virginia

By

Solar Turbines, Incorporated Product Development Center San Diego, California 


\section{DISCLAIMER}

This report was prepared as an account of work sponsored by an agency of the United States Government. Neither the United States Government nor any agency thereof, nor any of their employees, makes any warranty, express or implied, or assumes any legal liability or responsibility for the accuracy, completeness, or usefulness of any information, apparatus, product, or process disclosed, or represents that its use would not infringe privately owned rights. Reference herein to any specific commercial product, process, or service by trade name, trademark, manufacturer, or otherwise does not necessarily constitute or imply its endorsement, recommendation, or favoring by the United States Government or any agency thereof. The views and opinions of authors expressed herein do not necessarily state or reflect those of the United States Government or any agency thereof.

This report has been reproduced directly from the best available copy.

Available to DOE and DOE contractors from the Office of Scientific and Technical Information, 175 Oak Ridge Turnpike, Oak Ridge, TN 37831; prices available at $(615)$ 576-8401.

Available to the public from the National Technical Information Service, U.S. Department of Commerce, 5285 Port Royal Road, Springfield, VA 22161; phone orders accepted at (703) 487-4650. 


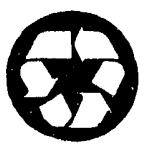

This cover stock is $30 \%$ post-consumer waste and $30 \%$ pre-consumer waste, and is recyciable. 


\title{
Advanced Coal-Fueled Industrial Cogeneration Gas Turbine System Particle Removal System Development
}

\section{Topical Report}

\author{
Michael Stephenson
}

Work Performed Under Contract No.: DE-AC21-86MC23166

For

U.S. Department of Energy

Office of Fossil Energy

Morgantown Energy Technology Center

P.O. Box 880

Morgantown, West Virginia 26507-0880

\author{
By \\ Solar Turbines, Incorporated \\ 9250 Sky Park Court \\ San Diego, California 92123
}

March 1994 


\section{INTRODUCTION}

The nature of gas turbine systems necessitate that the high temperature, high pressure gas entering the turbine be free of constituents that can cause erosive and corrosive damage. For gas or liquidfired systems, the gas stream is usually sufficiently clean to be unconcerned about erosion and corrosion. With coal-fired systems, however, the situation is quite a bit different. Sulfur oxides, particulate and alkall are all present and these constituents cause corrosion and erosion of the turbine. Therefore, any coal-fired system needs control systems for each one of these constituents.

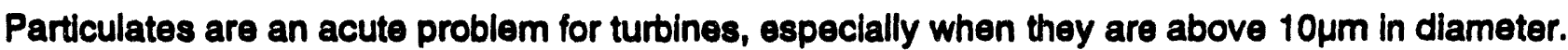
These solids need to be separated out upstream of the turbine to prevent damage. Environmental requirements for particulate, which do not yet exist for coal-based gas turbine systems, are likely to be more even more stringent then the turbine requirements. It was estimated, using existing regulations for coal combustion systems, that collection efficiencies of $99.9 \%$, or even greater, will be required to meet the anticipated environmental regulations.

Solar Turbines developed a direct coal-fueled turbine system (DCFT) and tested each component in subscale facilities and the combustion system was tested at full-scale. The combustion system was comprised of a two-stage slagging combustor with an impact separator between the two combustors. Greater than 90 percent of the native ash in the coal was removed as liquid slag with this system. In the first combustor, coal water slumy mixture (CWM) was injected into a combustion chamber which was operated lean to suppress $\mathrm{NO}_{x}$ formation. The slumy was introduced through four fuel injectors that created a toroidal vortex because of the combustor geometry and angle of orientation of the injectors. The liquid slag that was formed was directed downward toward an impaction plate, made of a refractory material, that served to collect the slag. Sixty to seventy percent of the coal-borne ash was collected in this fashion.

An impact separator, located between the two combustors, was used to remove additional slag that had escaped the primary combustor. The combined particulate collection efficiency from both combustors was above 95 percent. Unfortunately, a great deal of the original sulfur from the coal still remained in the gas stream and needed to be separated. To accomplish this, dolomite or hydrated lime were injected in the secondary combustor to react with the sulfur dioxide and form calcium sulfite and sulfates. This solution for the sulfur problem increased the dust concentrations to as much as $6000 \mathrm{ppmw}$. A downstream particulate control system was required, and one that could operate at 150 psia, $1850-1900^{\circ} \mathrm{F}$ and with low pressure drop.

Solar designed, developed and tested a particulate rejection system to remove essentially all particulate from the high temperature, high pressure gas stream. A thorough research and development program was aimed at identifying candidate technologies and testing them with Solar's coal-fired system. This topical report summarizes these activities over a period beginning in 1987 and ending in 1992.

\section{SUMMARY}

Several particulate rejection technologies were examined. These included high efficiency cyclones, ceramic bag filters, ceramic crossflow filters, electrostatic precipitators, granular bed filters, impact separators and ceramic candle filters. Only one technology, the ceramic candle filter, was tested. Two types of candle filters were tested, both of silicon carbide construction. These filters were tested in a subscale facility that operated at approximately 1 to 1.5 pps. 
The first series of tests were conducted using a silicon carbide filter manufactured by Schumacher of West Germany. These filters were of the same variety tested at the Grimethorpe pressurized fluidized bed facility (PFBC). Some of these candle filters failed with low service lives. A second candle filter, manufactured by Refractron for Industrial Filter and Pump Manufacturing Company, was tested with some mixed success. Failures were experienced with these candles as well, but they appeared more promising than the Schumacher candles.

\section{SYSTEM DESCRIPTION}

The DCFT system developed by Solar is shown in Figure 1. The system was comprised of a twostage slagging coal combustor, an impact separator for removal of molten slag, a sorbent injection system for sulfur control, and a ceramic barrier filter for particulate removal.

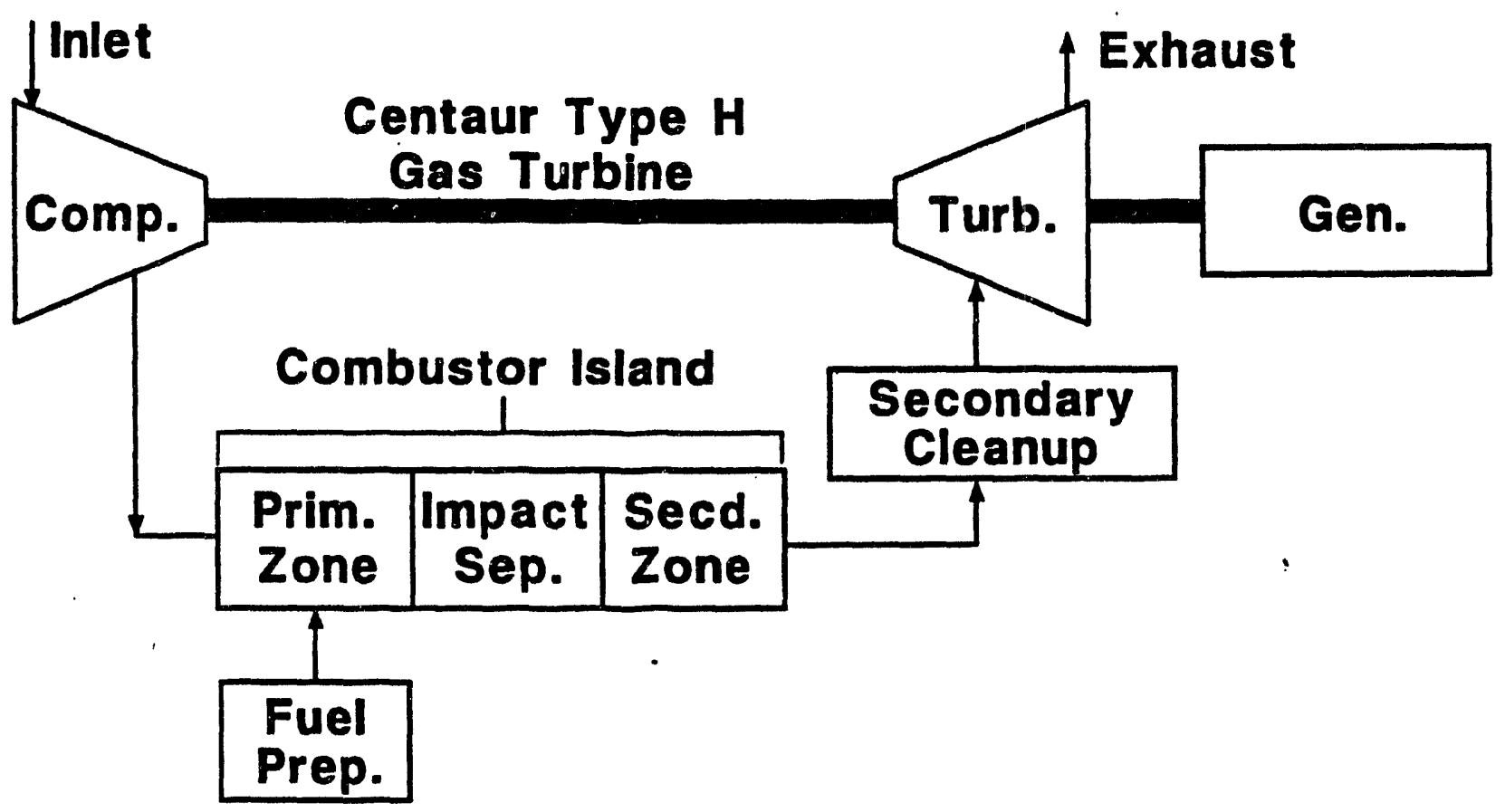

Figure 1. Solar's Direct Coal-Fueled Gas Turbine System.

Particulate was added to the system in two locations. First of all, the coal slurry fuel itself was comprised of particulates suspended in solution. Naturally, the ash portion of the fuel was not consumed, however, it was transformed to a viscous liquid state or slag. The slag had properties that permitted novel methods of separation. The second source of particulate was the sorbent that was added downstream of the secondary combustor to control sulfur oxides.

Particulate was removed in three locations. In the primary combustor, which was operated well above the slagging temperature of the coal, a toroidal vortex was created due to the injector design and orientation and the combustor geometry. Aerodynamic forces caused some $60-70 \%$ of the coalbome ash to be removed as liquid slag. Slag was removed from the combustor by gravity forces, and was collected in a slag pit. Since some of the coal-bome ash had still not been removed, an impact separator was used downstream of the combustor. This system was demonstrated to be highly successful in removing particulate. Some $95-97 \%$ of the coal-borne ash wis removed by the first two systems alone. 
The secondary particulate rejection system was located downstreatm of the secondary combustor and was used to remove essentially all particulate. At this stage in the system, the particulate was mostly spent or partially reacted sorbent, although there was some ash that was not removed in the primary combustor and the slagging impact separator. Since the sorbent did not enter the system until the secondary combustor, the primary slagging combustor and impact separator had no effect on removing sorbent emissions.

The effectiveness of the various control devices with both types of particulate is summarized in Table 1.

Table 1. Partlculate Removal In the DCFT System

\begin{tabular}{|c|c|c|}
\hline $\begin{array}{c}\text { Control } \\
\text { Device }\end{array}$ & \multicolumn{2}{|c|}{$\begin{array}{c}\text { Source of Particulate } \\
\text { Coal }\end{array}$} \\
\hline Slagging combustor & $60-70 \%$ removal & - \\
\hline PRIS & $90-99 \%$ removal & - \\
\hline Barrier Filter & balance & $99.9 \%$ removal \\
\hline
\end{tabular}

It is unfortunate that sorbent had to be added at all. In some cases, removal of enough coal-bome particulate occurred that a barrier filter was unnecessary. This in fact might be a viable system with an ultra-low sulfur coal. However, most coals are of sufficient sulfur content that sorbent is required. And when sorbent is needed, so is a barrier filter.

\section{STRATEGY}

The strategy that was employed was to follow these steps in sequence:

1) Define system requirements

2) Survey available technology for systems that can meet or potentially meet the system requirements.

3) Choose 2 or 3 technologies to test under actual conditions in a subscale rig.

4) Test the technologies chosen in 3.

5) Select a single technology for scale-up.

The requirements of the secondary particulate removal system were fairly well-defined at the outset. Nearly all the particulate, l.e., greater than $99.9 \%$, needed to be removed for environmental reasons and for turbine protection. The turbine inlet temperature for the Centaur is $1850^{\circ} \mathrm{F}$; therefore, the operating temperature of the particulate device was designed for the range of $1850-1900^{\circ} \mathrm{F}$. 


\section{TECHNOLOGY SELECTION}

A systematic process began to survey and select candidate technologies for removal of particulate from the high temperature, high pressure gas stream exiting the secondary combustor.

The initial survey of high temperature, high pressure particulate devices revealed that there were no devices in the current art that were fully tested at the temperature of choice, or if they were capable of withstanding the temperature of the system, they were unable to meet the stringent collection efficiencies that were required.

Uitra-high Efficiency Cyclone Cascade - A single-stage cyclone did not have adequate removal efficiency for final hot gas polishing and therefore, a multiple cyclone was required. Preliminary work performed by Asea-Stal Corporation in a PFBC application indicated that a three-stage cyclone cascade in some applications could produce a $3 \mu \mathrm{m}$ cutoff size. A cyclone design was submitted by Ducon is shown in Figure 2. However, the cost and complexity of the cyclone system were the primary reasons it was not pursued at the subscale level.

Impact Separator - Initial studies examined a dry mode impact separator, similar to that used in the combustor island between the primary and secondary combustors. This was eliminated from consideration because of low efficiency at low pressure drop, size considerations, and the likelihood of extensive reentrainment of a dry particulate.

Much later in the program, this concept was resurrected and studied further, mostly due to the documented test successes of the slagging impact separator. The new examination looked at this impact separator from the standpoint of adding a sticky material to increase capture of ash. The results of this study appear later in the report.

Ceramic Crossfiow Fitter - Preliminary studies were carried out on using a ceramic crossflow filter, based on Westinghouse/Coors technology. While ceramic crossflow filters showed great promise based on their high filtration area to volume ratio, the lower face velocities that were being used tended (approximately $3 \mathrm{fpm}$ ) to negate that advantage. Also, there were some early problems with delamination. Since these filters were already being tested by Westinghouse under a variety of conditions, and the technology was under development, it was decided to not test these in Solar's system. Ceramic crossflow filters are shown in Figure 3.

Ceramic Bag Fiters - Ceramic bag filters were examined and appeared to be a technology worthy of testing, provided certain barriers could be overcome. A major problem plaguing bag filters was pinhole formation, splitting at a seam and alkali attack. Ceramic bag filters are shown in Figure 4.

A system was designed for testing bag filters, made of Nextel 440 . Bags were even obtained as well as handware to suspend them from the tubesheet, however, due to budget constraints, this system was never tested.

Ceramic Candle Filtere - Ceramic candle filters appeared to have the most merit of any of the devices examined. They were considered relatively simple and did not have the mechanical problems of crossflow filters and the degradation and strength problems of the ceramic bag filters. They had been tested for long duration at PFBC conditions. And although problems were evident, they appeared to have the highest probability of success. They also appeared to have good potential for improvement as new binder formulations were developed for the high temperature range. Ceramic candle filters are shown in Figure 5. 


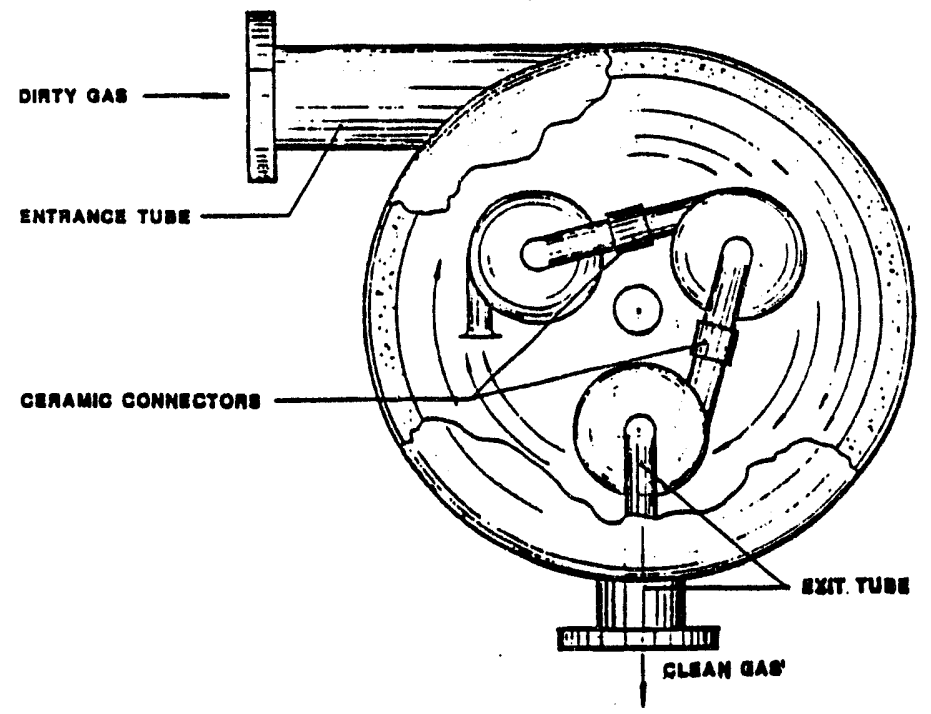

SUBSCALE CYCLONE. SYSTEM-TOP VIEW.

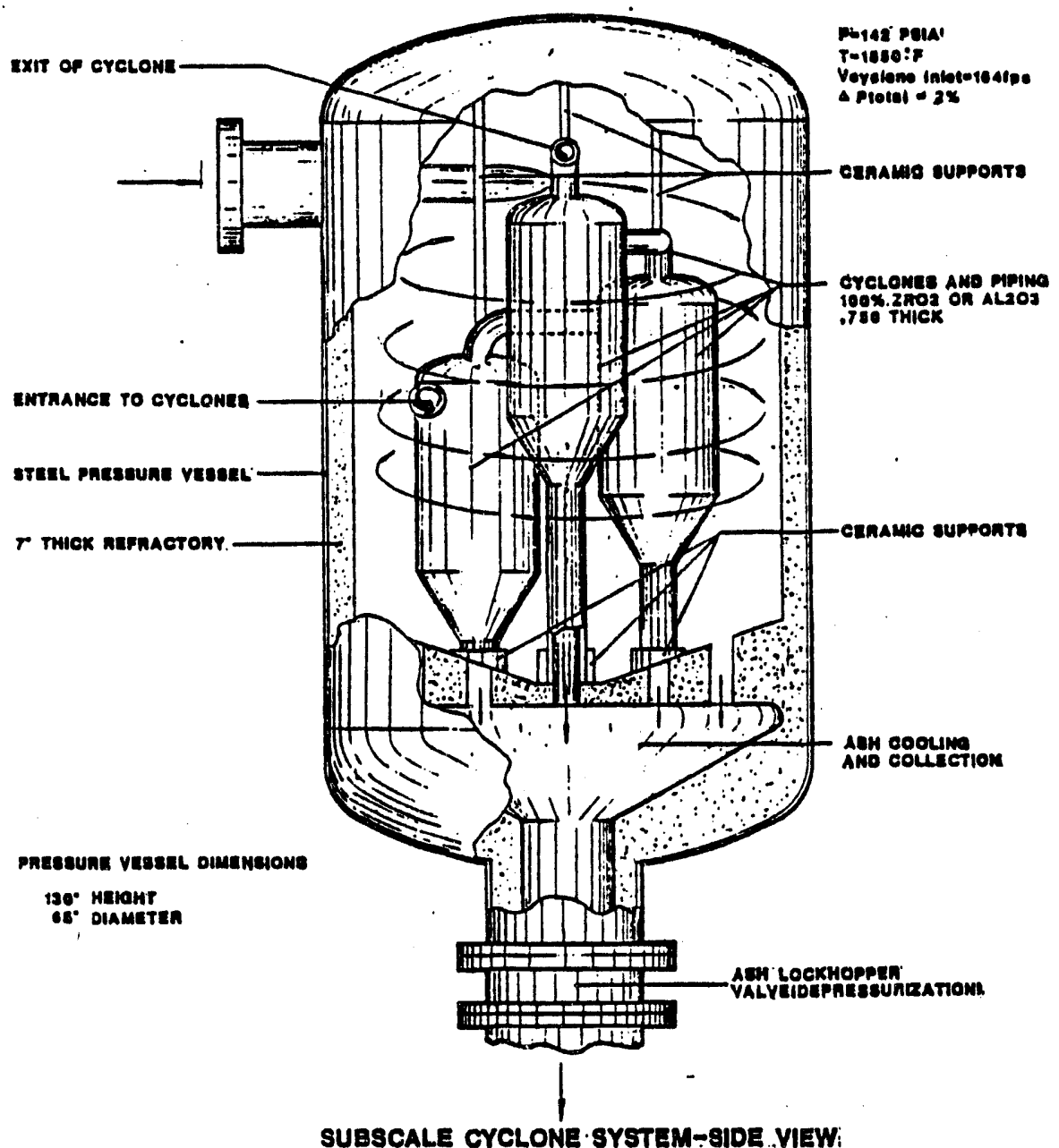

Figure 2. Subscale Multiple Cyclone System 


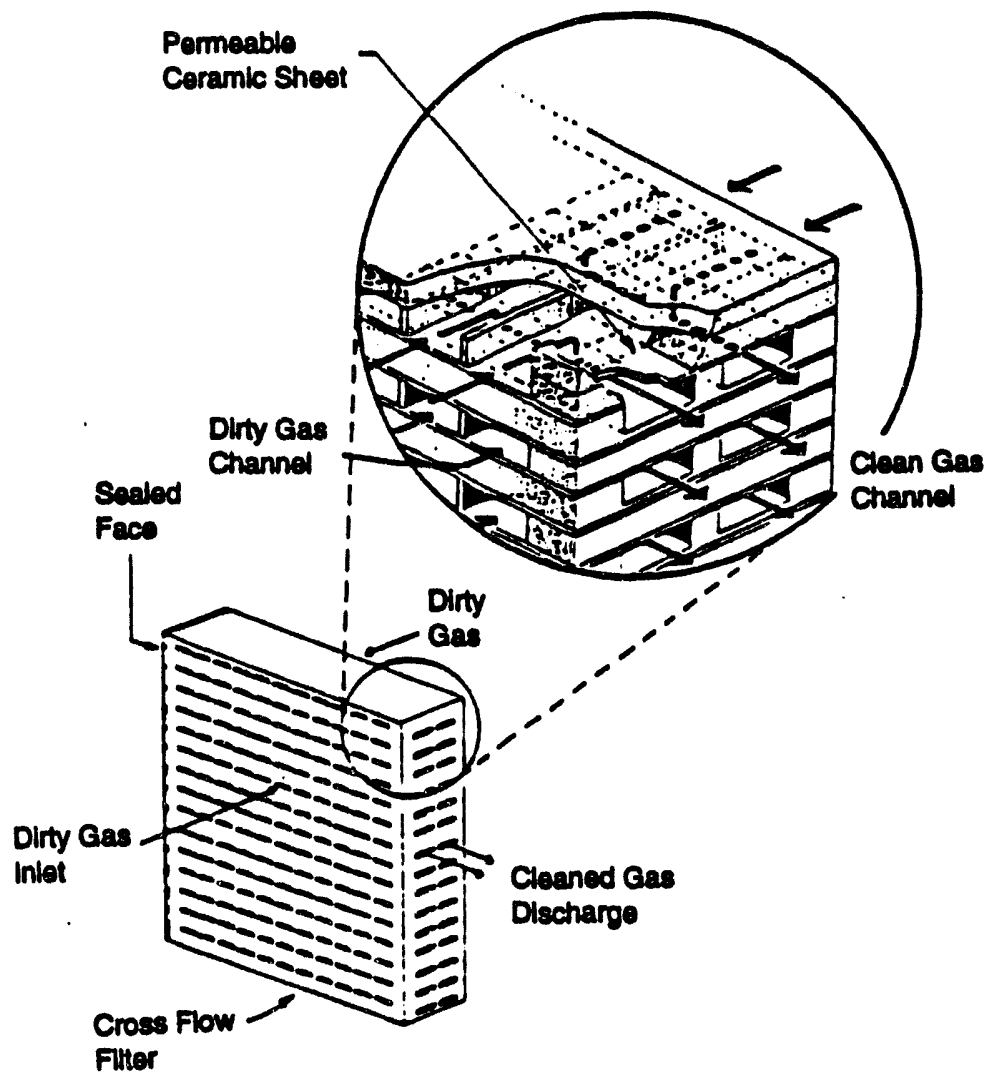

Figure 3. Ceramic Crossflow Filter

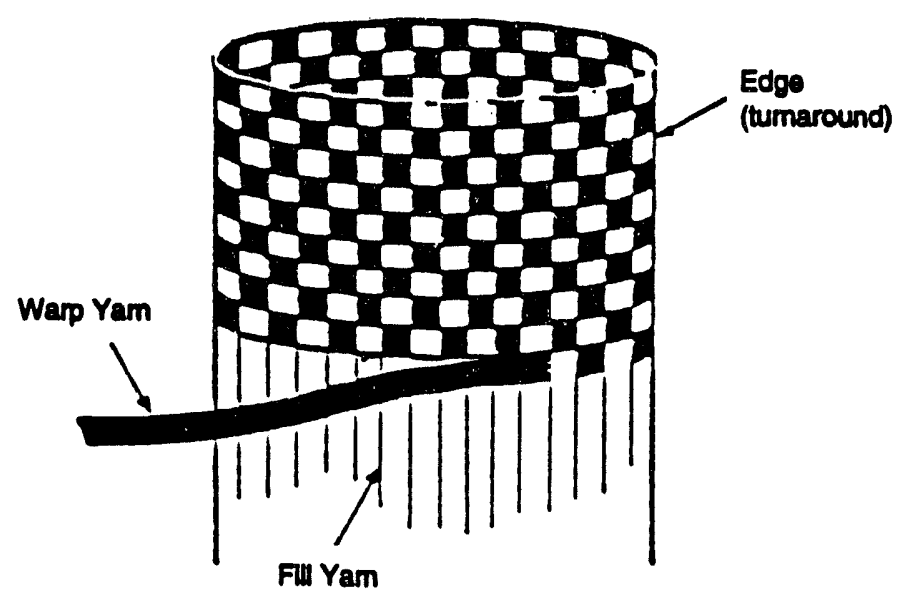

Figure 4. Ceramic Bag Filter 


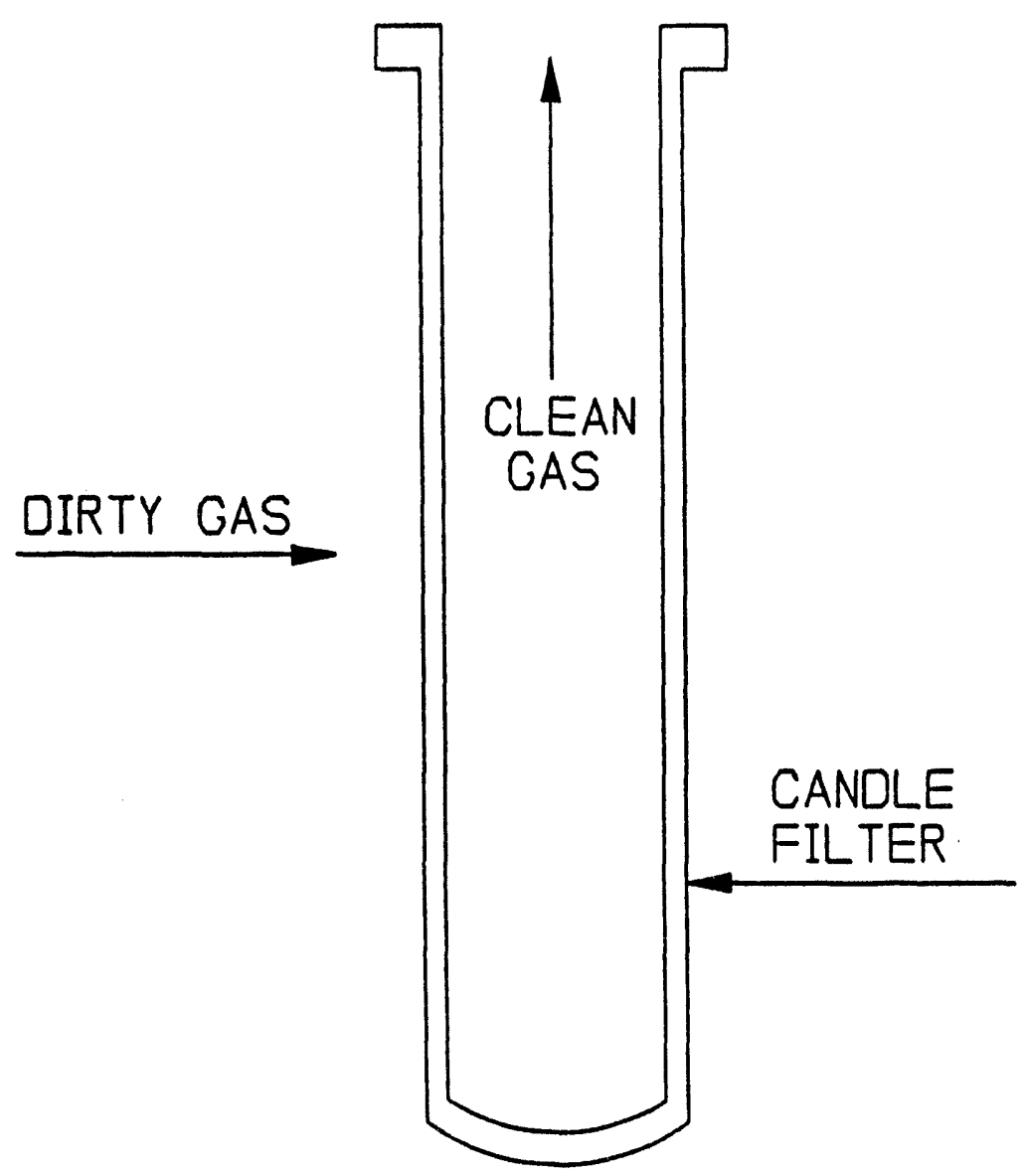

Figure 5. Ceramic Candle Filter

Ceramic barrier filters were considered a prime candidate technology and most of the ensuing work was focused on testing them.

The initial design of the Integrated Bench Scale Test Facility (IBSTF) included a pressure vessel that could accommodate various tubesheets and hence, various particulate collection devices. Three technologies were selected for initial evaluation using the IBSTF. They were the ceramic candle filter, the ceramic bag filter and the ceramic crossflow filter. Only the ceramic candle filter was tested. The crossflow filters were not tested because of funding constraints and similar ongoing research while the ceramic bag filters were not tested due to budget constraints and their low likelihood of success.

These final choices, however, were all barrier filters, where a porous material, in these cases a ceramic, acts as a filter to permit the flow of gas, but prohibit the transfer of particulate matter. These materials add a pressure drop to the system as a dust layer forms on the upstream surface of the filter. With time, the pressure crop increases. Periodically, it is necessary to purge the barrier filter by directing a higher pressure jet of air, or other gas, at the filter from the downstream side. This dislodges the dust cake and reduces the pressure drop to the so-called clean pressure drop. 


\section{INTEGRATED BENCH SCALE TEST FACILITY}

A subscale test facility was designed and built in order to test candidate technologies for the Solar DCFT system. The facility was designed, built, commissioned, tested, environmental permits and variances were obtained, and ultimately, two fiter systems were tested. The process of procuring environmental permits and variances tumed out to be the most time consuming of all the steps, but approvals were finally given after system modifications and environmental testing were performed as requested.

\section{SYSTEM DESCRIPTION}

The main test rig for filter testing was given the name Integrated Bench Scale Test Facility (IBSTF). This rig as it wes originally designed (Configuration $I$ ) is shown schematically in Figure 6. There were two purposes for this rig:

- Test the Particulate Rejection Impact Separator (PRIS) and arrive at a material selection

- Test various HTHP particulate separation technologies and arrive at a technology selection

The PRIS was tested ahead of the HTHP particulate separation technologies for a couple of reasons. First of all, it was important to ascertain that all, or nearly all, coal-bome slag particles were removed by the PRIS, so that large, corrosive and sticky particles were not being sent to the HTHP separation device. Therefore, a battery of tests were conducted initially to determine the PRIS collection efficiency; this was discovered to be quite adequate at well above 90 percent. The test results of the PRIS are described in a separate report (LeCren et al.).

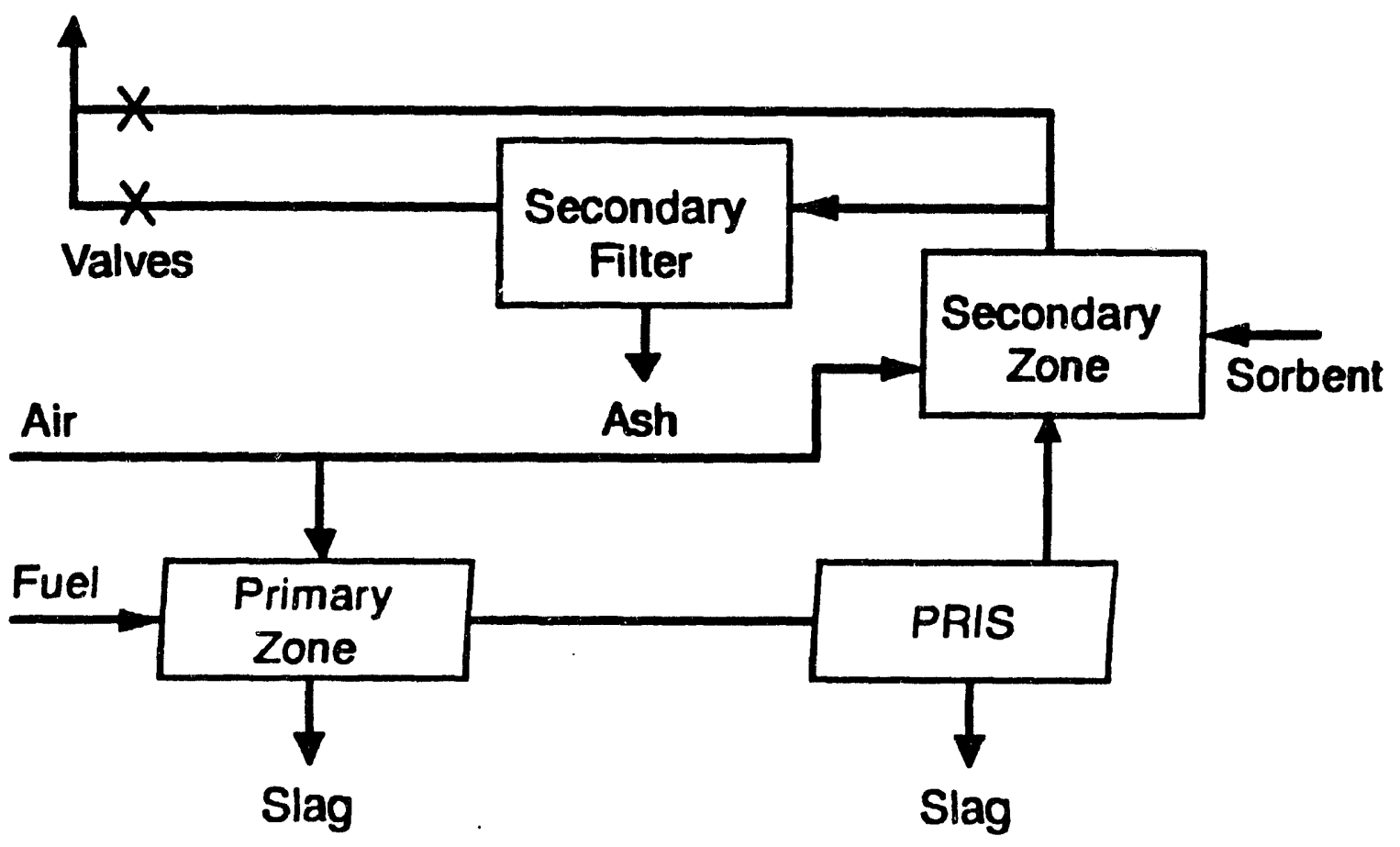

Figure 6. Integrated Bench Scale Test Facility - Configuration I 
The IBSTF was designed as a one-tenth full-scale test facility. The testing of the filter device was planned at $1 / 3$ of this or $1 / 30$ th of the full-scale system. The IBSTF was comprised of a combustor island and a cleanup section which included the filter vessel with filters and the purge system.

The combustor island included a primary and secondary combustor and a slagging impact separator. The primary combustor was operated in a high temperature slagging mode at conditions richer than stoichiometric to minimize the conversion of nitrogen bound in the coal to $\mathrm{NO}_{x}$. The geometry of the primary combustor was such that aerodynamic forces contributed to a $70 \%$ removal of mineral matter as liquid slag. Downstream of the primary combustor was the particulate rejection impact separator, or PRIS, where nearty all the remaining slag was removed. The PRIS design was based on the effect of jet impaction of slag droplets onto a collection surface. An array of staggered ceramic rods were used to separate out the molten slag.

The secondary combustor was operated at about $1900^{\circ} \mathrm{F}$. Sorbent was injected for sulfur control in this zone. Either hydrated lime or dolomite were used, depending on the sulfur content of the coal slurry. The particulate loading increased considerably in this zone even though little of the coalbome ash remained.

A refractory-lined fitter vessel was employed to house the filtration test elements. This filter vessel was downstream of a flow split section where two-thirds of the main flow was routed around the vessel. The remaining third of the flow was routed directly to the filter vessel.

Downstream of the filter vessel was a refractory-lined flow nozzle to measure the flow of the gas passing through the filter vessel. This enabled the face velocity to be measured and controlled in real time during a test. The flow of gas passing through the filter vessel was adjusted using a pair of butterfly valves, one each in the main and bypass lines. Water was injected upstream of each of these valves to lower the gas temperature. The two lines were joined and eventually exhausted to atmosphere through a stack. Earty runs used a cyclone to separate out remaining particulate. Later runs used a combination venturi scrubber/cyclone to remove the particulate.

The IBSTF was originally designed as a one-tenth scale rig. It was modified several times during the course of its operation. However, the various modifications are best segregated into two basic configurations. These are denoted here as Configuration I, and Configuration II. Configuration I was the original design of the system: a 1/10-full scale combustion/PRIS system, with a 1/30 full-scale filtration system. Configuration II was a downsized Configuration I, with all components being 1/30 full-scale.

What follows is a somewhat brief history of the development of the IBSTF from its initial conception to its final from.

\section{RIG DEVELOPMENT}

Initially, the IBSTF was designed so that a number of potential HTHP particulate removal technologies could be sested. The strategy included using tubesheets of various designs to enable a variety of filter systems to be tested. Initially, seven configurations were planned which included a static granular bed filter, ceramic candle filters, ceramic candle filters with a granular bed filter, ceramic bag filters, ceramic bag filters with granular bed, a moving granular bed, and a cross-flow filter. The financial and time constraints for testing several devices were sufficient to abancion all but the candle filter testing. 
The initial design of the IBSTF system included a filter vessel of fixed size which was able to accommodate various tubesheets for different filtration systems. Because of the high temperature of the DCFT system, considerable study into the tubesheet design was undertaken.

It was considered virtually impossible to use a stainless tubesheet at $1850-1900^{\circ} \mathrm{F}$ without some sort of cooling of it. At the Grimethorpe PFBC, which operated at temperatures around $1600^{\circ} \mathrm{F}$, a tubesheet of RA-330 was used. For the Solar design, a 316 stainless tubesheet was used that had serpentine channels milled directly into the tubesheet. Water at a low flow rate was used so as to keep the tubesheet surface temperature at or below $400^{\circ} \mathrm{F}$. According to an ANSYS analysis, this should have resulted in a heat flux of about 6000 Btuhr. Test results did not bear this out, however; actual heat losses were much higher. While the serpentine design permitted more than adequate cooling, it resulted in a larger than usual candle spacing. This results in a much larger filter vessel on scaleup. However, for the subscale testing, it was adequate in providing what was required.

Temperatures of the water-cooled tubesheet were measured and recorded. Twenty-two thermocouples were mounted directly on the tubesheet surface, eleven on each side. The temperature of the water enteri" $y$ and exiting the tubesheet was also recorded. Therefore, the temperature loss of the gas passing insugh the filter vessel was equal to the sum of the heat losses to the cooling water as well as the heat lost through the walls of the vessel.

The heat flux to the water coolant was constant and independent of the coolant flow rate in the range of 4.2 to $10.4 \mathrm{gpm}$. The flux was generally around 79,000 Btu/hr. At this flux, and with the gas flows that were recorded through the vessel, an average temperature loss due to water cooling was calculated to be about $105^{\circ} \mathrm{F}$. A sampling of the data is shown in Table 2.

Table 2. Water-cooled Tubesheet Data

\begin{tabular}{|c|c|c|c|c|c|}
\hline \multirow[b]{2}{*}{ Date/Time } & \multirow[b]{2}{*}{$\begin{array}{c}\text { Flow Rate, } \\
\text { gpm }\end{array}$} & \multirow[b]{2}{*}{$\begin{array}{l}\text { Temp } \\
\text { Alse, }{ }^{\circ} \mathrm{F}\end{array}$} & \multirow[b]{2}{*}{$Q_{\text {maner }}$} & \multicolumn{2}{|c|}{$\Delta T_{\text {and }}\left({ }^{\circ} F\right)$} \\
\hline & & & & Calculated & Measured \\
\hline 10 May, 21:10 & 10.4 & 14.5 & 72,384 & 93 & 254 \\
\hline 11 May, 7:39 & 10.4 & 15.2 & 75,878 & 105 & 165 \\
\hline 11 May, 15:38 & 6.0 & 7.6 & 79,488 & 97 & 258 \\
\hline 12 May, 4:42 & 6.0 & 28.7 & 82,656 & 110 & 241 \\
\hline 12 May, 7:07 & 6.0 & 27.6 & 79,488 & 117 & 243 \\
\hline 12 May, 10:12 & 6.0 & 29.5 & 84,960 & 112 & 257 \\
\hline 12 May, 14:12 & 4.2 & 38.5 & 77,616 & 102 & 219 \\
\hline
\end{tabular}

Configuration 1- The one-tenth flow was spilt off into two streams, one stream being a bypass, the other going to a filter vessel. The flow split was roughly one third to the filter vessel and two-thirds to the bypass. 
The IBSTF was comprised of a two-stage slagging combustor as well as the slagging impact separator, or PRIS. The secondary combustor was fitted with a continuous sorbent injection system which fed sorbent into the secondary zone for reaction with the sulfur. The flow was split downstream of the secondary combustor. The stream to be filtered was routed to the filter vessel to pass through the filtration medium. The back pressure of both streams, filter and bypass, were controlled by two butterfly valves. This permitted the flow rate through the filtei vessel to be regulated.

Conflguration II - Configuration II, shown schematically in Figure 7, was basically a downsized combustor/PRIS version of Configuration I. The flow rate through the filter vessel remained roughly the same. The primary reason for the downsizing was to obtain the necessary environmental approvals from the Air Pollution Control District (APCD) of the County of San Diego. This was judged to be the quickest method to obtain the permits needed to finish the testing that had already begun. The advantage of this configuration was that the entire flow was being filtered; this enabled the particulate emissions to be more fully contained.

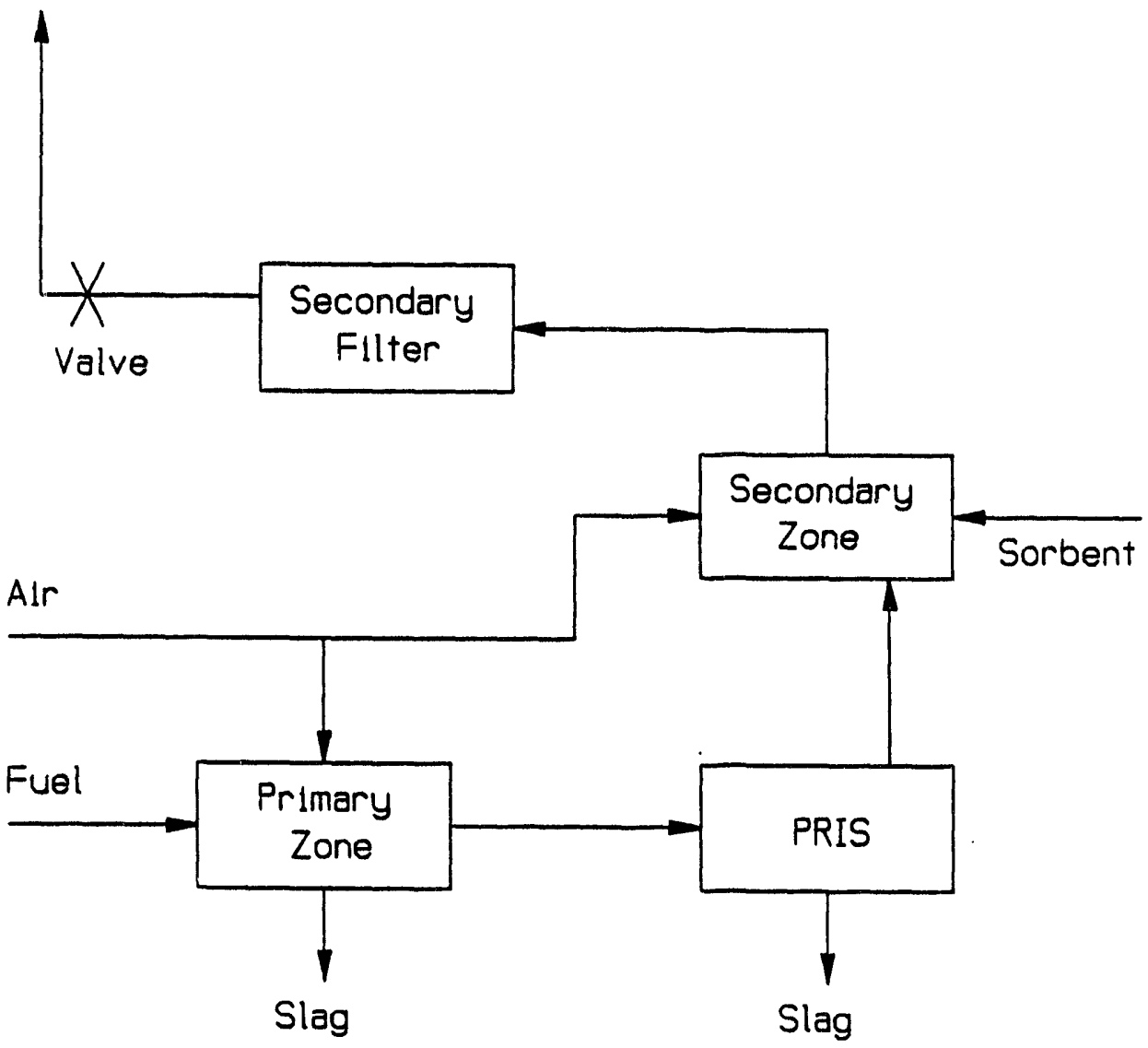

Figure 7. Schematic Dlagram of IBSTF - Configuration II

Filter Vessel - A refractory-lined, filter vessel, shown in Figure 8, was designed to accommodate ceramic candle filters, crossflow filters or ceramic bag filters. Two water-cooled tubesheets were designed and constructed. One of these was designed to suspend 14 candle filters while the other was designed for eight ceramic bag filters. The bag filters were slightly larger in diameter than the candle filters (4.25-inch versus 2.36-inch), hence the reduced number of filters. 


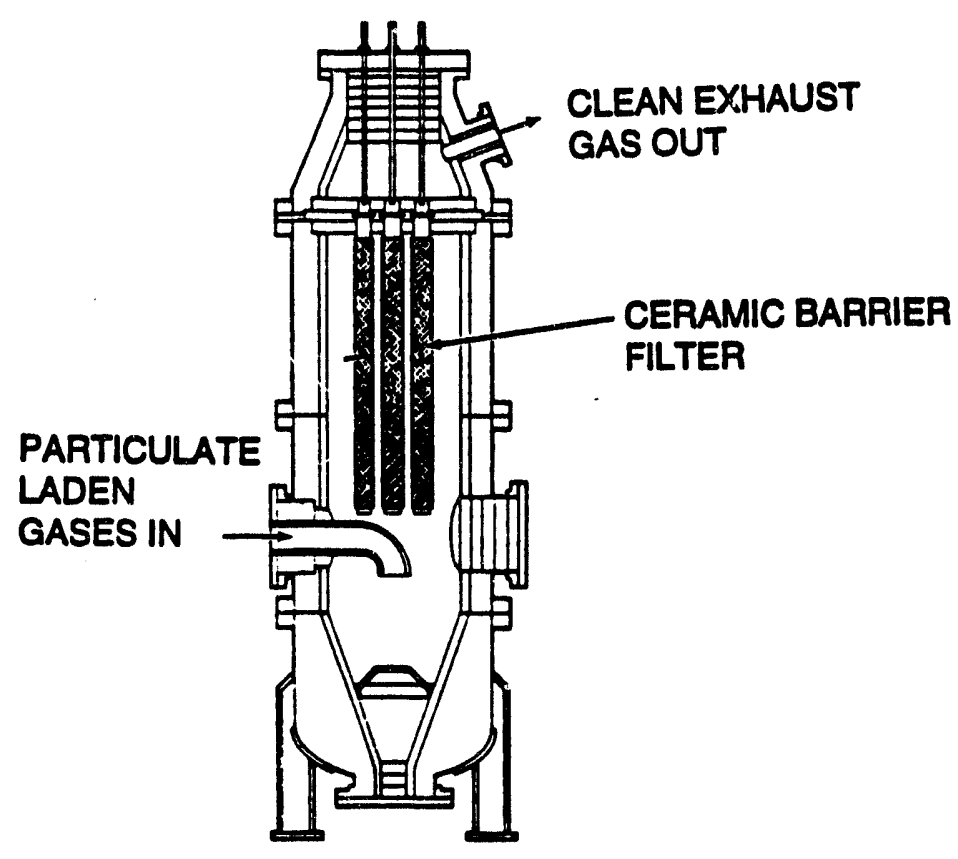

Figure 8. Subscale Filter Vessel

The tubesheet, $5 \mathrm{~cm}$ thick and $109 \mathrm{~cm}$ in diameter, was manufactured of 316 stainless steel with water cooled, serpentine channels. A fabric bellows design was employed to ensure a gas tight seal and to allow for thermal expansion. The tubesheet was designed to keep surface temperatures around $400^{\circ} \mathrm{F}$, thus eliminating the need for a super alloy tubesheet such as RA-330. Both upstream and downstream surfaces of the tubesheet were fitted with 11 type $K$ thermocouples each and the cooling water inlet and outlet temperatures were measured. The water-cooled tubesheet in shown in Figure 9.

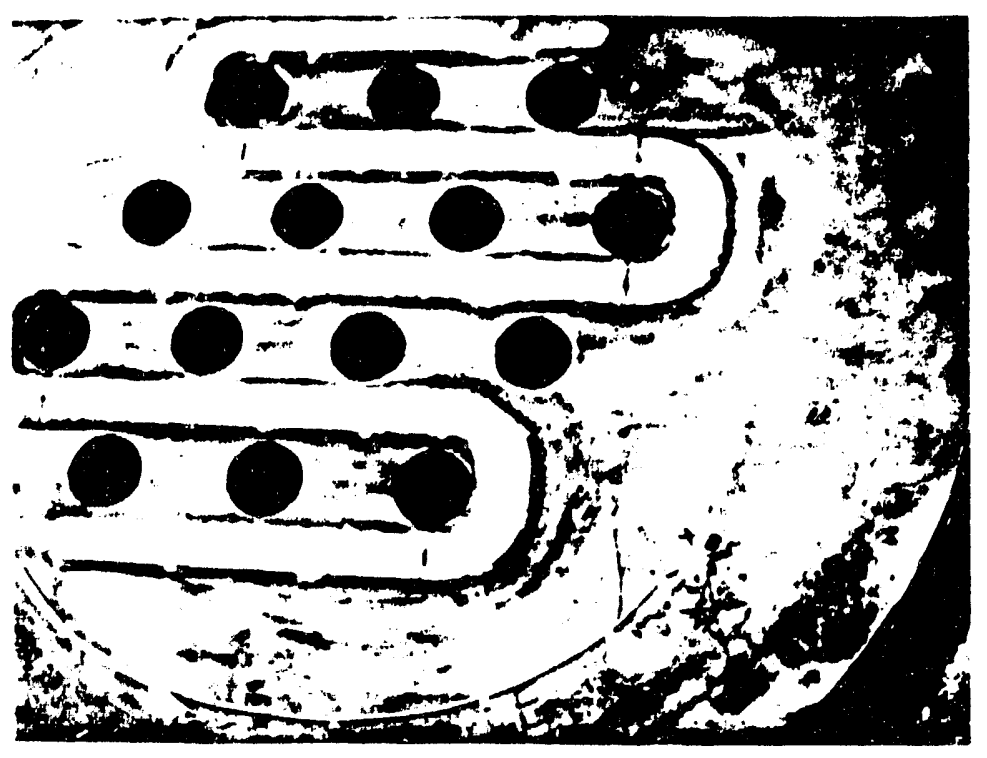

Figure 9. Water-cooled Tubesheet 
To minimize heat losses from the tubesheet, it was insulated top and bottom with Kaoboard high temperature insulating board. Two layers of Kaoboard materials were used to match the expected temperature profile. These boards were attached to the tubesheet using Inconel posts and washers which proved effective.

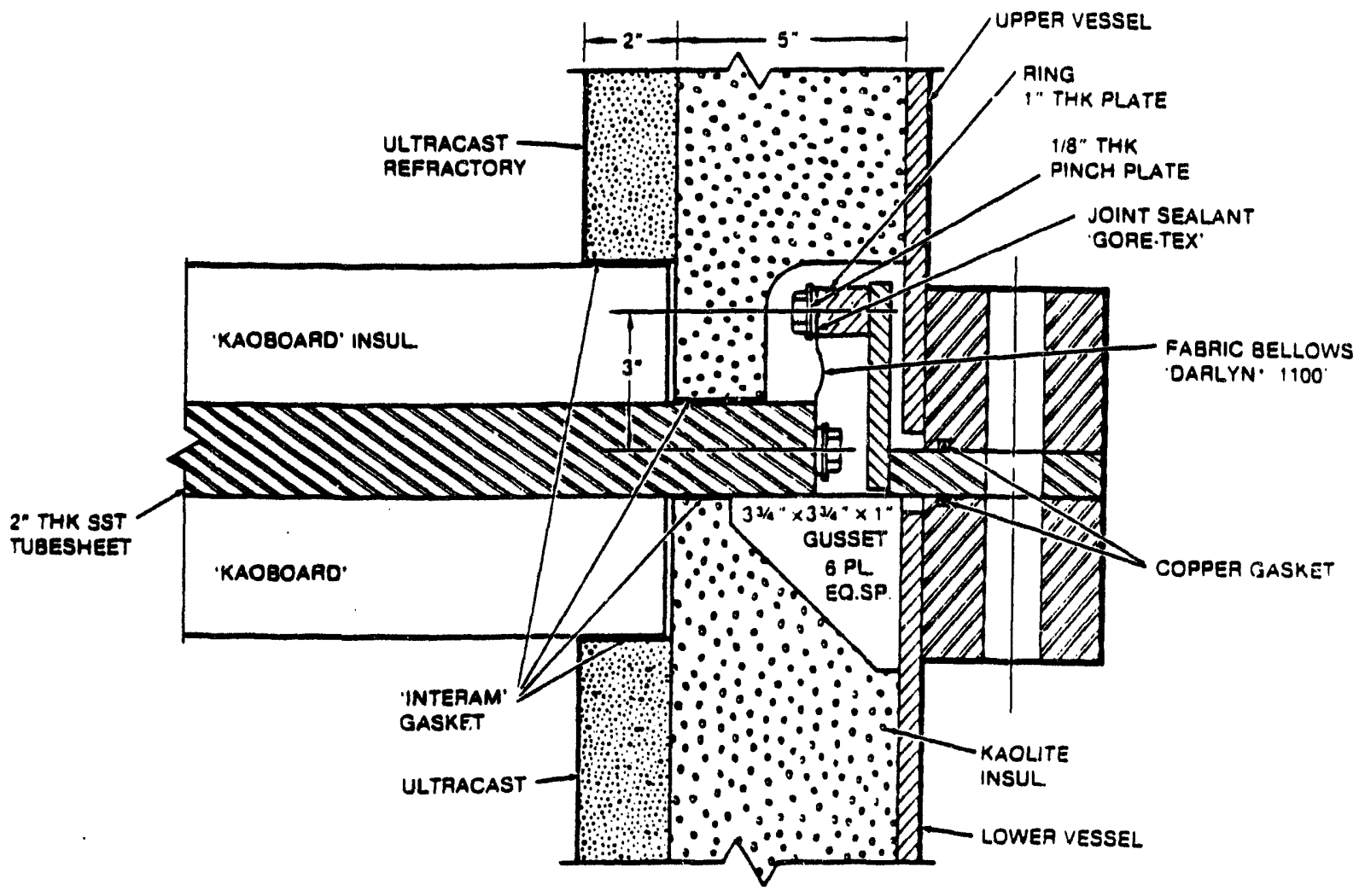

Figure 10. Tubesheet Bellows Detail

The candle tubesheet was machined to accept 14 candles having a total filtration area of $3.9 \mathrm{~m}^{2}$ (42 sqft).

Candle Attachment Method - Attachment of candles is to a tubesheet has historically been problematic. At the Grimethorpe PFBC, weights to provide a force greater than any expected pressure differentials were used to keep the candles in place. However, transients exceeded the expected maximum, the weights bounced and candles failed. Solar decided to test two methods, one a rigid-mount system, the other, a non-rigid system. The rigid mount system was based on Solar's patented mount system for ceramic recuperator tubes. Basically, the candle was cemented into a Hastelloy-X cup using a refractory material. This cup was then edge-welded to a Hastelloy- $X$ sleeve, located on the tubesheet. This enabled candles to be installed and removed relatively quickly and at the same time, providing a complete air-tight seal. This mount method is shown in Figure 11. 


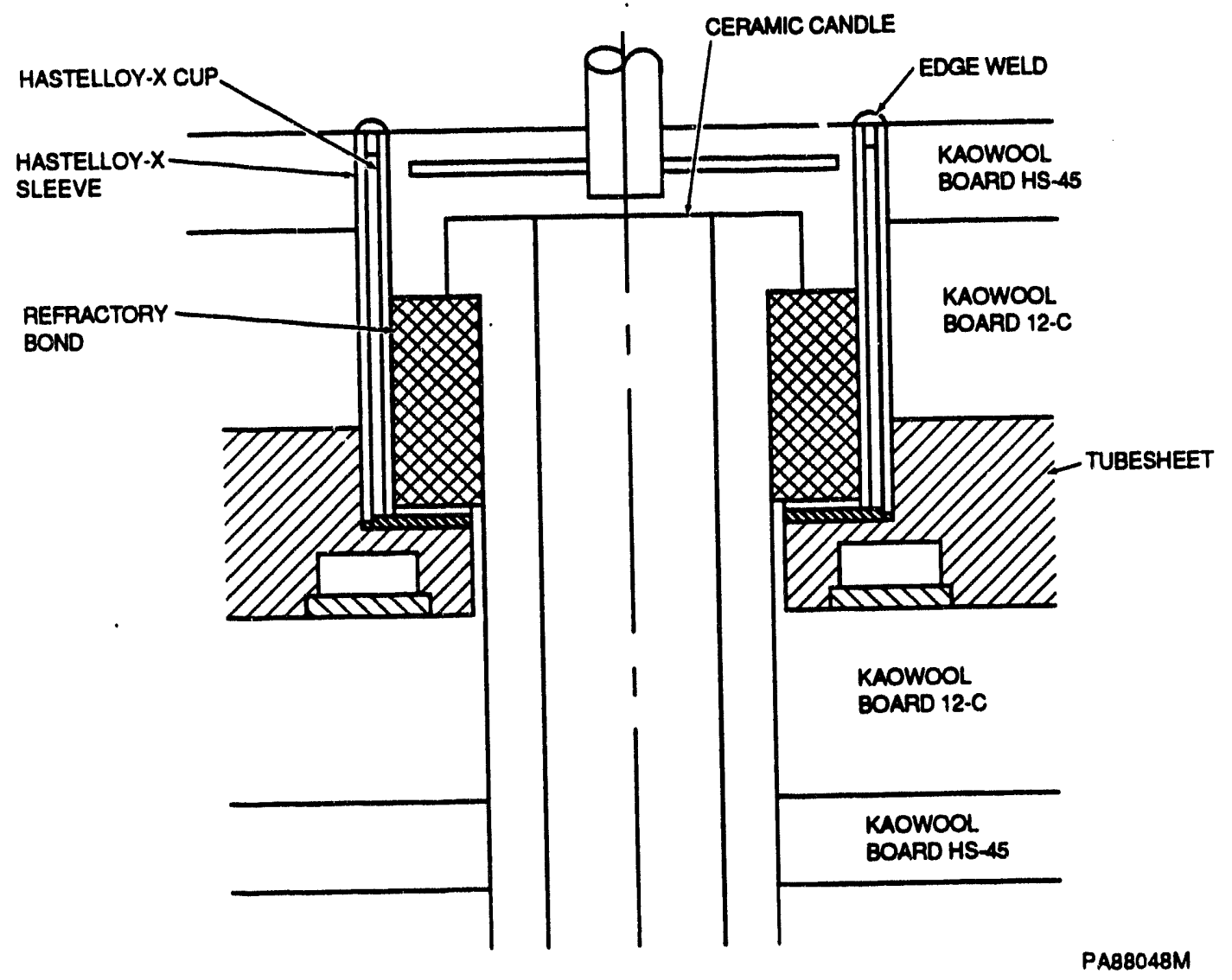

Figure 11. Refractory-Bonded Candle Mount

The gasket-based candle mount was based on technology of Industrial Filter and Pump Manufacturing Company (IF\&P) is shown in Figure 12. In this design, two Interam gaskets are used. One is located below the candle flange which provides the basic seal. A second gasket is used on top of the candle along with a stainless washer. This arrangement sandwiches the candle flange. Two pins are placed horizontally on top of the candle, gasket and washer assembly and are themselves welded to a cup arrangement.

Purge System - During filtration, it is necessary to periodically clean barrier filters of their accumulated dust by applying a short duration, high pressure pulse in the reverse direction. Generally, less than one second duration is adequate. Depending on dust loading and face velocity conditions, filters need purging as often as every 3 minutes or as little as once an hour. The onset of purging is driven by either cycle time or pressure drop.

A four manifold system was designed and used at the IBSTF. Each manifold contained one solenoid valve and one ball valve. In the event a solenoid valve stayed open for longer than one second, an electronic controller would actuate a ball valve, thereby protecting the filters from thermal shock.

The purge tubes were constructed from Haynes 230 to ensure adequate life. The purge system is shown in Figure 13. 


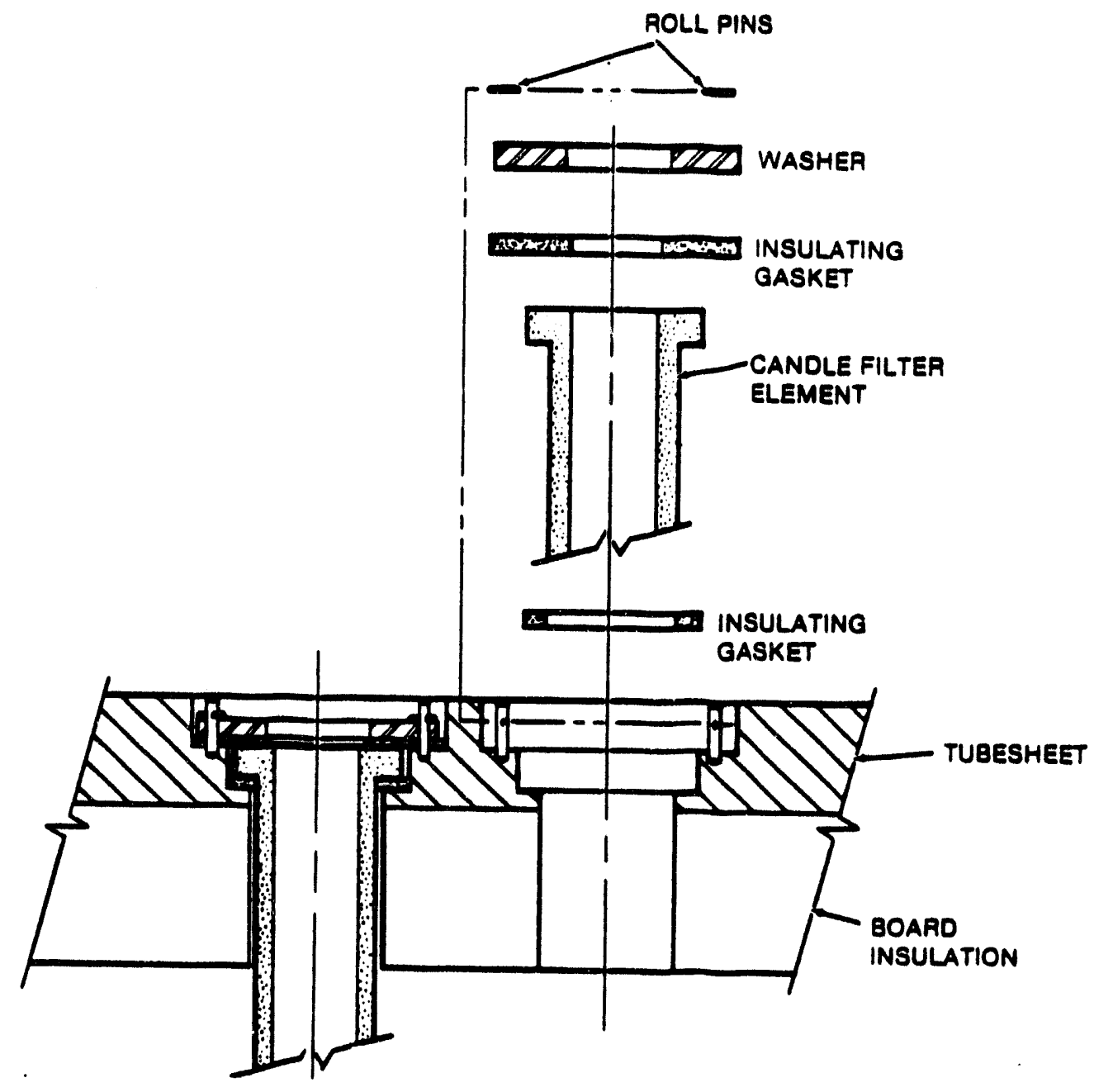

Figure 12. Gasket Candle Mount

Emisslons systems - The IBSTF was originally designed with a single stage cyclone to remove residual particulate matter in order to meet the County of San Diego Air Pollution Control District regulations. The system was retrofitted some time after operation to include a venturi scrubber, so as to remove additional particulate from the stack. The cyclone and venturi scrubber proved to be only marginally effective in Configuration I. The performance gradually worsened with time in operation. However, without the bypass loop, the particle loading to the scrubber was greatly reduced, as the entire flow was being filtered. Therefore, the emissions were expected to be much lower in Configuration II than in Configuration I.

Estimation of filtration collectlon efficlency - While the ceramic candle filters were known to provide excellent filtration in excess of $99.9 \%$, measurement of it under test conditions helped to measure real-time filtration efficiency. At the IBSTF, collection efficiency was measured by taking an isokinetic sample using a critical flow nozzle matched to the flow velocity. This sampled gas stream was passed through a Balston absolute filter to quantitatively collect all dust. Both inlet and outlet streams were sampled in this manner. The tubing carrying the sample gas was water-cooled in a double pipe arrangement as the gas at $1800^{\circ} \mathrm{F}$ needed to be cooled to below $450^{\circ} \mathrm{F}$ to prevent damage to valving. The flow was split in a $Y$ tube to two different filters. This enabled a sample to be taken continuously by diverting the flow to the desired filter housing once a data point was taken. 


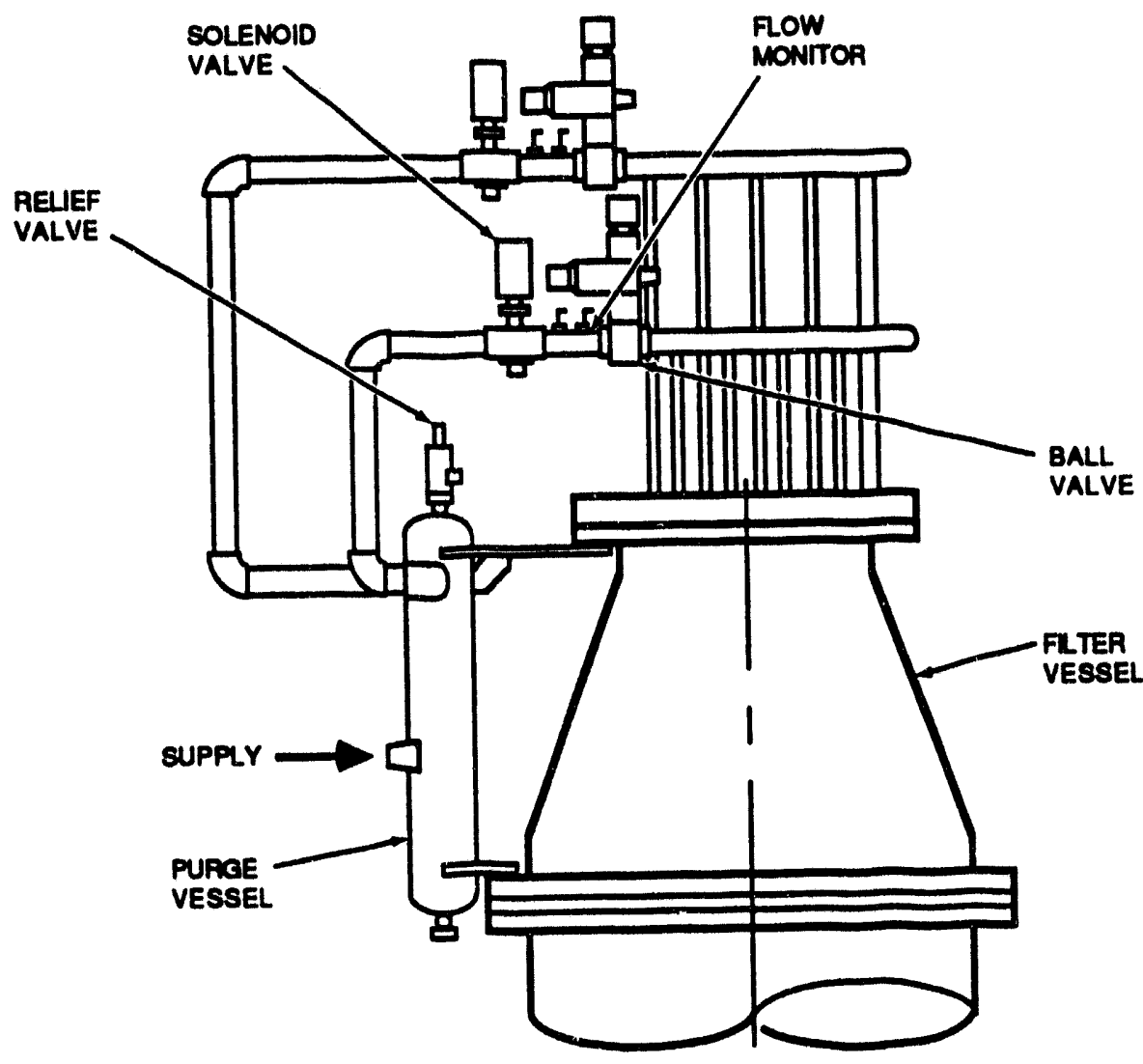

PA88055M

Flgure 13. Candie Fliter Purge System

Once a sample was taken, it was dried in an oven to drive off moisture, and then weighed to determine the amount of collected dust. The collection efficiency was measured by taking the measured dust concentration at the outlet subtracted from the inlet dust concentration and dividing that result by the dust concentration at the inlet and multiplying by 100 percent.

\section{FILTRATION TESTS}

Due to cost constraints and technical considerations, only candle filters were tested in the program. Ceramic bag filters were abandoned early in the program, primarily due to the problems attendant to using bags in a high temperature environment with alkall present in the gas stream. Crossflow filters had been considered as well. However, considerable development work was already being periormed by Westinghouse.

Candle Filters - Candle filters are rigid, ceramic tubes that are flanged at the top end and closed or capped at the bottom. Most candle designs use two layers to minimize pressure losses. The inner layer is coarse grained, large pores and comprises the bulk of the candle. Its prime purpose is to impart strength to the candle. Typically, the outer layer is relatively thin and is fine grained to provide excellent filtration characteristics.

Two varieties of candle filters were tested, although both were of silicon carbide construction. The first series of tests were conducted using the Schumacher Dia-Schumalith F40 sillicon carbide filter. The second series of tests were conducted using the Refractron 50/5 sillicon carbide filters. While similar in some aspects, these candles differed in performance in the DCFT system. 


\section{Schumacher Dia-Schumalith candle filters}

The Schumacher Dia-Schumalith F40 candle filters were chosen in 1988 to be the first barrier filter to be tested. At the time, Refractron candles were not yet available, and the candle filters being marketed by Industrial Filter and Pump were of inconsistent quality. The only viable choice at the time were the Dia-Schumaliths. These candles had recently seen service in two prominent installations. For a PFBC application, they were tested at Grimethorpe, England by the Electric Power Research Institute. They were also tested in the KRW gasifier, an IGCC application. However, these candles had not previously been tested for a DCFT application. They were judged to be the best avallable candle technology at the time the decision to test them was made.

Properties of the Dia-Schumalith are listed in Table 3.

\section{Refractron Candle Filters}

Two types of candle filters were.provided by Refractron/ndustrial Filter and Pump. While both were of sillcon carbide construction, they differed in binder composition. Both binders were proprietary formulations and are denoted here as the 505 candle and the 442-T candle. The 442-T was designed to be alkali-resistant.

One primary test that Industrial Filter and Pump used for quality control was a permeability test. They measured the air flow at a fixed 2-inch water column pressure drop. The results of these tests are shown in Figure 14 for the 505 candles and in Figure 15 for the 442-T candles.

The candles were relattvely consistent as shown by the bar graphs. The only outllers were two 442 $T$ candles that were of unexpectedly low porosity. These were replaced with candles that were within range.

Industrial Filter and Pump performed bubble point testing to determine the pore size distribution or distribution range. A small range appeared to have certain advantages, including higher strength. These are shown in Figure 16, which compares the Dia-Schumalith candle to the two Refractron candles.

\section{Schumacher Dia-Schumalith Filter Testa}

The IBSTF was commissioned in 1989. The first series of tests were conducted to test the PRIS and to establish enough data to acquire the necessary environmental permits for the rig. Candles were installed in the system in late 1989 for testing in 1990. Two shakedown tests were conducted in earty 1990. The first test was conducted with coal water slurry fuel; the second test was conducted using diesel fuel $\# 2$ with dolomite being injected.

First shakedown test - The first test was run for three hours. No particulate sampling was performed. The candles were operated at face velocities between 6.0-9.4 fpm. The temperatures in the filter vessel inlet rose steadily during the run from $1323^{\circ} \mathrm{F}$ at the test beginning to $1771^{\circ} \mathrm{F}$ at the end of the run. The gas temperature dropped steadlly as it passed through the vessel. For example, the temperature at the flow nozzle at the beginning of the run was only $803^{\circ} \mathrm{F}$. By the end of the run, it had risen to $1280^{\circ} \mathrm{F}$. The temperature in the filter vessel, however, ranged from $977^{\circ} \mathrm{F}$ initially, to $1570^{\circ} \mathrm{F}$ by the end of the run. 
Table 3. Properties of the Schumacher Dla-Schumalith F40 Candle Filter

\begin{tabular}{|c|c|}
\hline Property & Value \\
\hline Length, mm & $1515 \neq 10 \mathrm{~mm}$ \\
\hline Outer Diameter, mm & $60 \pm 1 \mathrm{~mm}$ \\
\hline Inner Diameter, mm & $30 \pm 1 \mathrm{~mm}$ \\
\hline Woight, $\mathrm{kg}$ & $6200+200 /-100 \mathrm{~kg}$ \\
\hline Filtration area, $\mathrm{m}^{2}$ & 0.26 \\
\hline Specific Permeability, NPm & $1.98 \times 10^{2}$ \\
\hline Filtration fineness (nominal), $\mu \mathrm{m}$ & 1.0 \\
\hline Component, supporting body & Coarse ceramic granule (SIC) \\
\hline Component, microporous diaphragm & $\begin{array}{l}\text { Fine ceramic granules } \\
\text { Mineral Fibers }\left(\mathrm{Al}_{2} \mathrm{O}_{3}\right)\end{array}$ \\
\hline Granule/Filter diameter, $\mu \mathrm{m}$ & $300 / 3$ \\
\hline Average Pore diameter, $\mu \mathrm{m}$ & support body av. 100 \\
\hline Maximum pore diameter, $\mu \mathrm{m}$ & 10 \\
\hline Maximum temperature, ${ }^{\circ} \mathrm{C}$ & 1000 \\
\hline Average porosity, $\%$ & 35 \\
\hline Specific Heat, KJ/kgK & 1.1 \\
\hline Thermal Expansion Coeff., $\left(10^{-1}\right) 1 / K$ & 5.2 \\
\hline Bending Strength, $\mathrm{MPa}$ & $>11$ \\
\hline Initial Pressure Drop, mbar $\$ 200 \mathrm{~m} / \mathrm{h}$ & $6 \pm 2$ \\
\hline Particle collection efficiency, \% & $>99.9$ \\
\hline Bursting pressure, bar & $>60$ \\
\hline Young's modulus dense region, $\mathrm{GPa}$ & 75 \\
\hline Young's modulus porous region, $\mathrm{GPa}$ & 40 \\
\hline Density dense reglon, $\mathrm{g} / \mathrm{cm}^{3}$ & 2.1 \\
\hline Density porous region, $\mathrm{g} / \mathrm{cm}^{3}$ & 75 \\
\hline
\end{tabular}




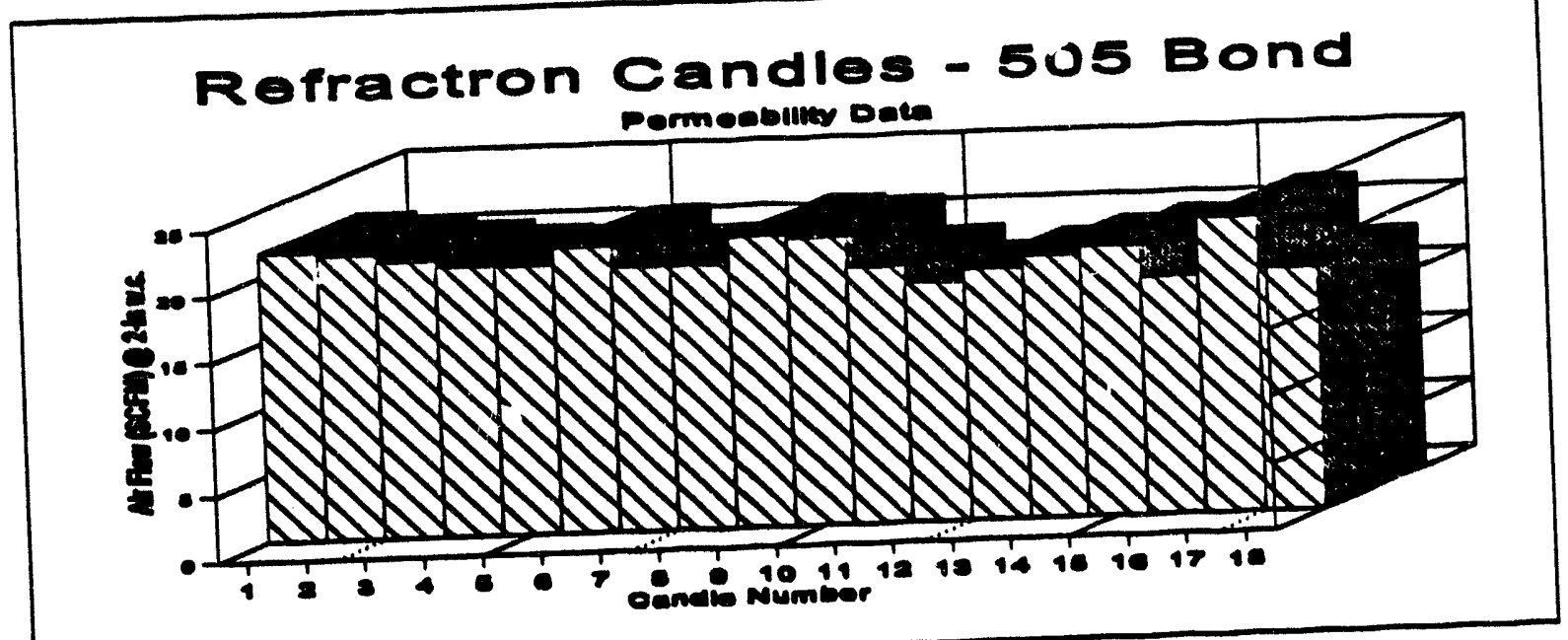

Figure 14. Poroaity Data for Rofractron Candles, 505 Binder.

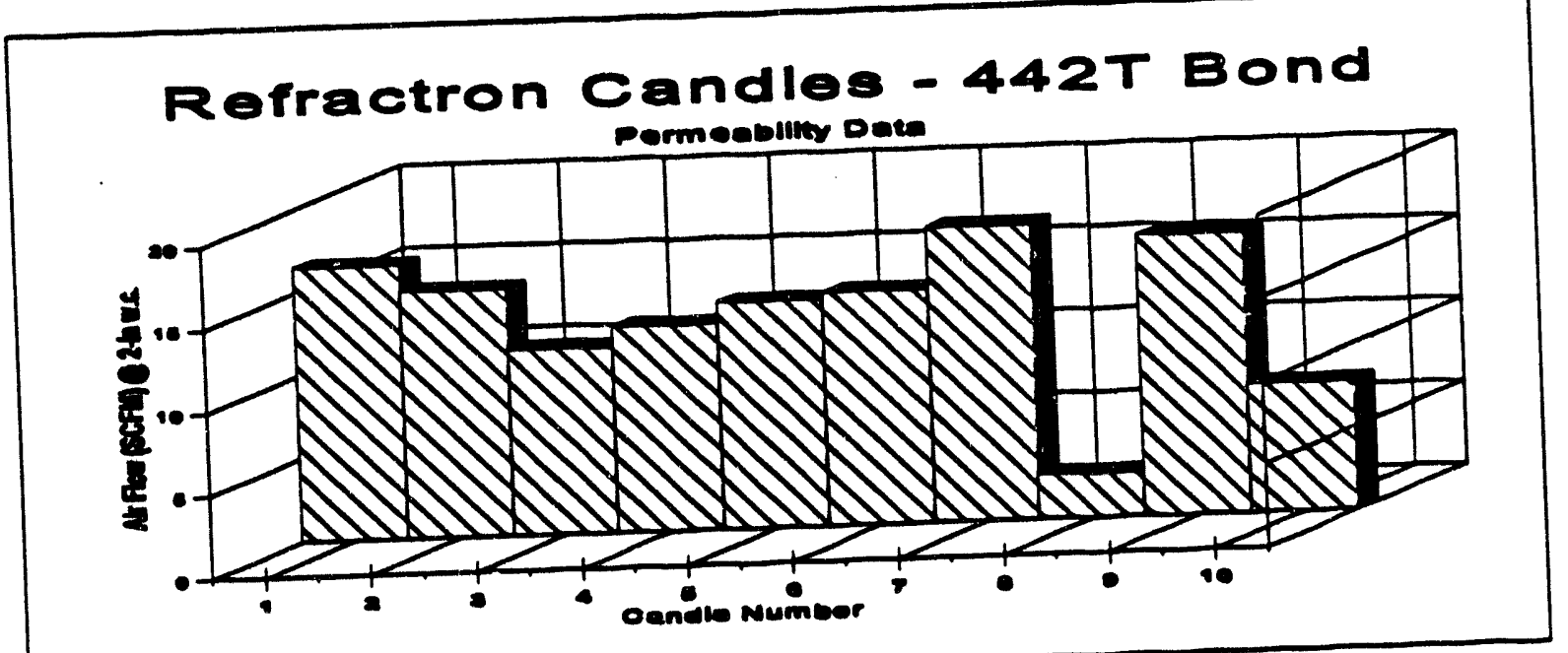

Figure 15. Poroalty Data for Refractron Candles, 442-T Blnder. 


\section{Mean Pore/Large Pore Data}

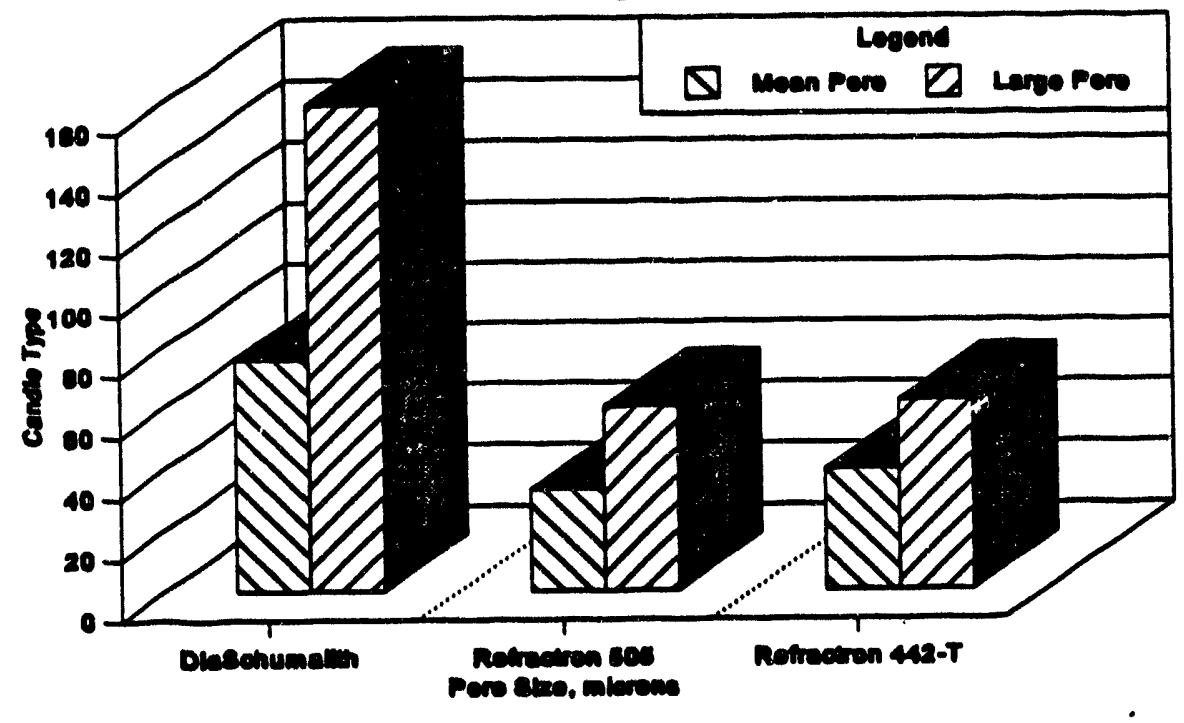

Figure 16. Mean Porelarge Pore Data for Schumacher and Refractron Candles

The dust loading was estimated to be 2400 ppmw of sorbent (plus any additional particulate matter from the coal slumy and the air supply). A visual inspection of the candles following the test showed that all fourteen candles were intact and relathely clean of dust. Following the test, $7.7 \mathrm{lbs}$ of dust were collected from the bottom of the filter vessel. Small amounts of dust were attached at the lower end of each candle. This indicated that the purge was probably successful at the upper section of the candle. A higher purge pressure might have been more successful in removing the dust from the lower sections of the candles. The purge pressure was set at 200 psig which was 120 psi above the secondary filter pressure (80 psig).

Differential pressure versus elapsed time data were collected by using a data acquisition system, a personal computer and customized software to log the data to disk. These data were imported to a spreadsheet and finally plotted. The result is shown in Figure 17. Although not shown on this graph, the differential pressure on the diesel heatup was negligible. Once on coal, however, the pressure increased gradually with time. This was more coincident with the introduction of sorbent, which occurred at the same time coal slumy was introduced to the combustor. A single purging cycle was effected when the differential pressure reached 1.6 psid. The entire purge cycle was completed within 30 seconds and this is seen in the shap decline in the differential pressure at the 3 hour mark.

The IBSTF system, because of its sheer size, could not be run at steady state conditions in the filter vessel until several hours of heatup. Therefore, only ranges of conditions can be stated.

These are shown in Table 4.

Second shakedown test - A second shakedown test was performed with diesel fuel and injected dolomite. The primary purpose of this test was to test the particulate sampling system, which was comprised of two isokinetic sample stations (one upstream and one downstream) and to measure the collection efficiency of the candles. 


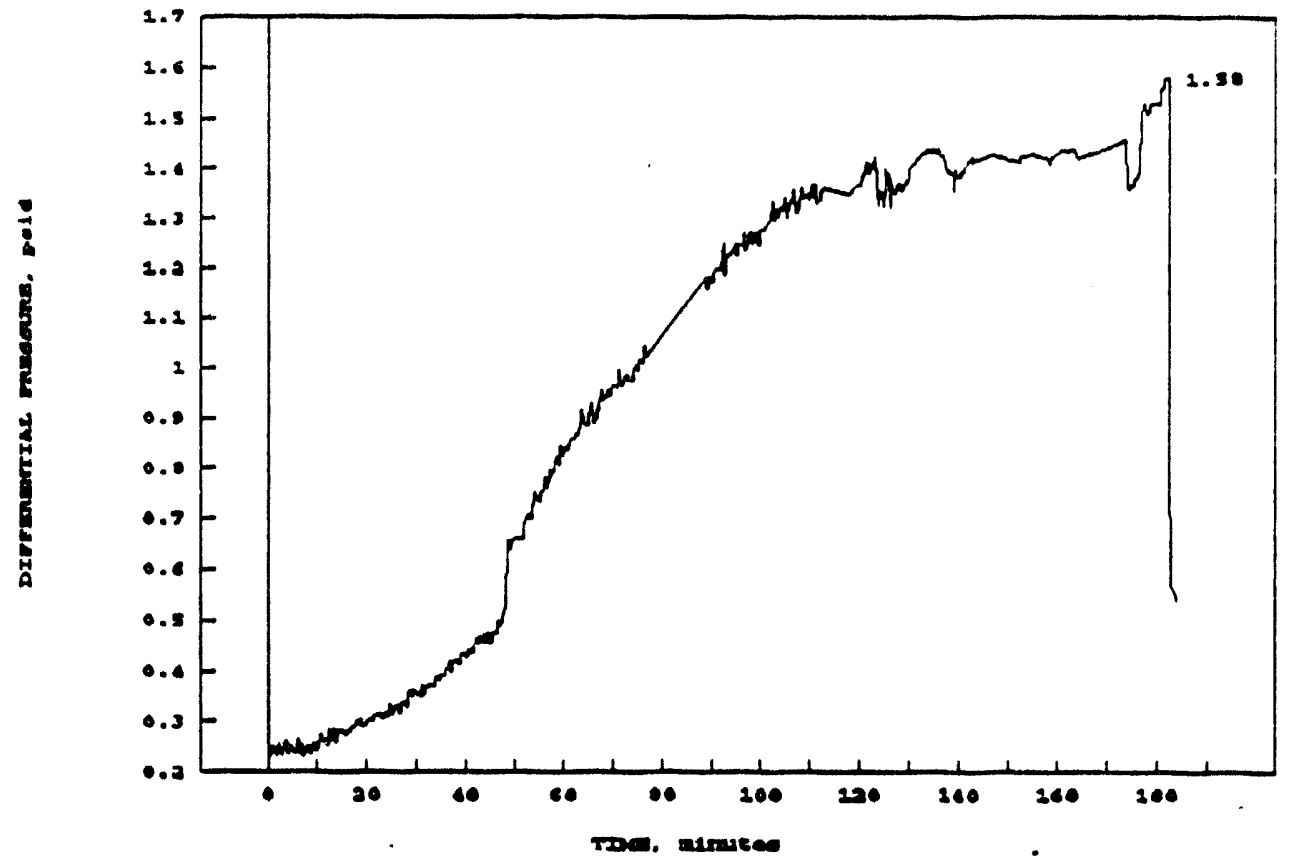

Figure 17. Differential Pressure Versus TIme Data for Schumacher Dla-Schumallths

Table 4. Candle Filter Operating Parameters, Shakedown Teat

\begin{tabular}{|ll|}
\hline \multicolumn{1}{|c|}{ Parameter } & \multicolumn{1}{c|}{ Range } \\
\hline Face velocity, fpm & $6.0 \cdot 9.4$ \\
Filter vessel temperature, ${ }^{\circ} \mathrm{F}$ & $975 \cdot 1570$ \\
Pressure, psia & 95 \\
Differential pressure, psid & $0-1.9$ \\
Estimated dust loading, ppmw & 2400 \\
\hline
\end{tabular}

During the test, diesel fuel was bumed and dolomite was injected at the secondary zone. Sampling time for the upstream port was five minutes. The cleaner downstream station was operated for one hour. This permitted sufficient sampling time to collect a weighable sample. For this test, a collection efficiency of $99.92 \%$ was measured. This indicated that the filters were effectively filtering the gas of dust and the candle attachment method was functioning as designed.

Earthquake occurrence - Following the shakedown test, a manhole cover was opened up to remove the sorbent that was collected. Visual inspections showed that the candles were intact. Within two days of the inspection, a mild earthquake of magnitude 4.7 cccurred in San Diego County. The next day, two candles were discovered to have broken. The date coincidence of this failure indicates that the earthquake, while mild, was sufficient to result in two candles failing. However, what is unclear is what strength degradation occurred as a result of the shakedown test. The two candles were adjacent. This raises the possibility that one candle broke, and upon falling, it struck the other, causing it to break. Both candles broke within 5.5 inches of the top of the candle. 
Following the earthquake, two as-new candles were installed into the vessel, and the rig was prepared for a longer duration test on coal water slumy.

"Fity-hour test" - The long-duration run, intended for 50-hours, was conducted in May 1990. The test was run over the course of a few days, beginning with a two-day heatup of the system on diesel fuel, followed by an orderly transition to coal water slurry fuel. The original intent was to run the system for two full days to $\log \mathbf{5 0}$ hours of exposure on coal slurry fuel.

Two candle filters failed sometime during this test. These candles were not adjacent. Therefore, an occurrence of one candle failing and striking a second candle can be ruled out. The location of the two candles that failed is shown in Figure 18. Both candles were on the perimeter of the vessel; however, in this system, $71 \%$ of the candles were perimeter mounted. Therefore, the probability of the failure locations occurring in this manner purely by random events, was $50 \%$.

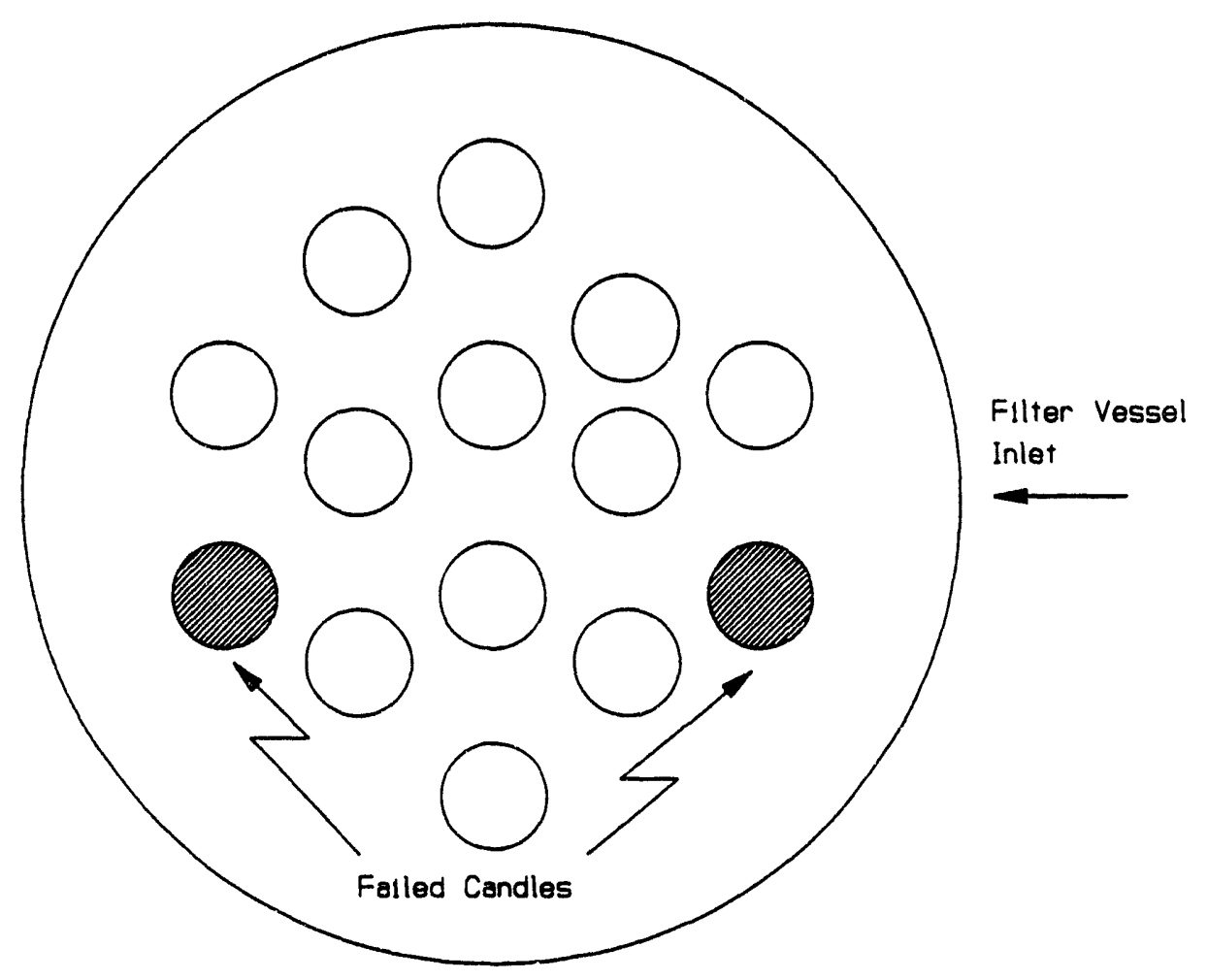

Figure 18. Filter Vessel Locatlon of Falled Schumacher Candle Filtere

Perhaps more noteworthy is not where in the vessel the failed candles were located but where on the candle did the break occur. Both candles falled within seven inches of the top fiange. This is not totally unexpected when comparing this data to the KRW gasifier tests and to the other occurrences of candle failures, as shown in Figure 19. 


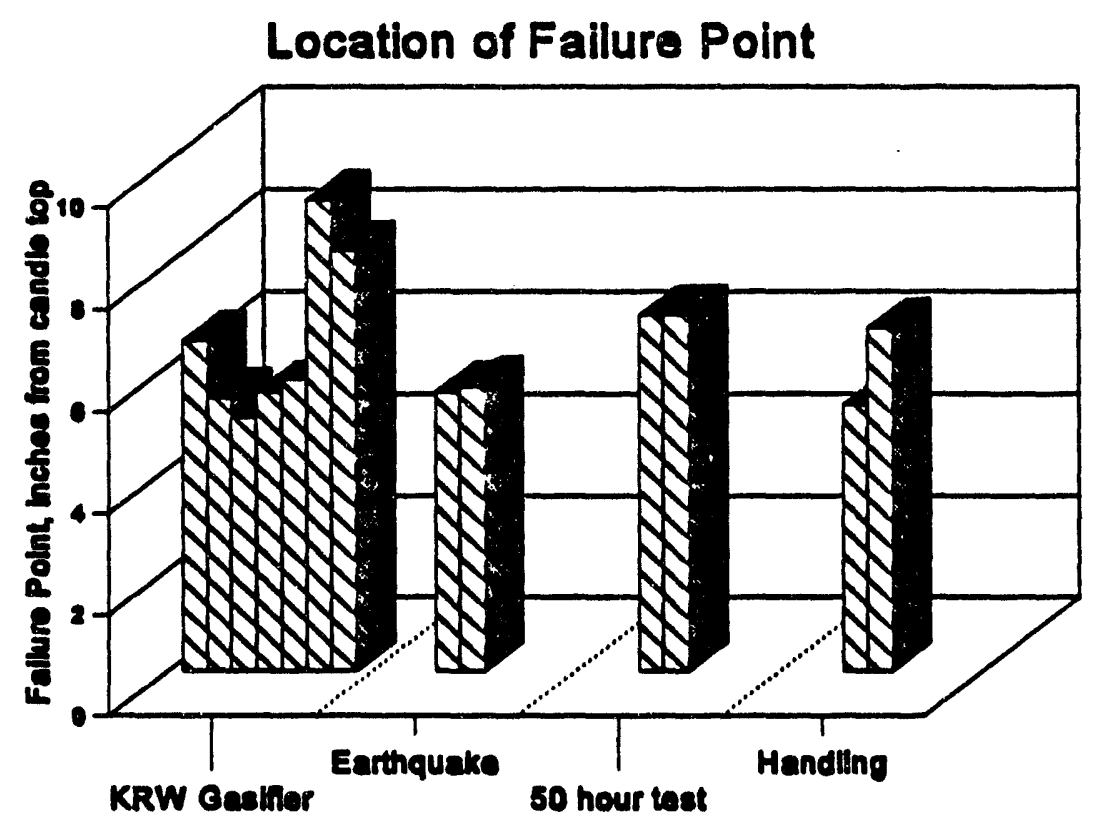

Figure 19. Fallure Polnt Location on Schumacher Candles Filters

\section{Schumacher Dia-Schumalith Filters - Post-Exposure Testing}

Exposure testing was performed at Acurex Corporation. The testing at Acurex will be discussed first. Examination of used and unused filters was done to assess the effects of exposure on the filters. These examinations included:

- $\quad$ Visual examination
- $\quad$ Xcanning Electron Microscopy with Energy Dispersive Spectroscopy (SEM/REDX)
- Four-point bend testing

Examination of the unused filters provided the baseline.

Operating Conditions - The operating data showed that the candles were in operation for approximately 6 hours when a failure occurred. The apparent time of failure was noted by a decrease in the filter vessel differential pressure. At the time of failure, the vessel temperature was approximately $1100^{\circ} \mathrm{F}$.

Visual Examination - The candles were well-packed and shipped to Acurex for examination and testing. When one of the failed candles was received, is was reconstructed and both sides of the cracked surface were examined. Two holes were discovered on the interior surface of the candle. One hole was fairly large, measuring approximately $3 \mathrm{~mm}$. This hole extended from the inside surface approximately $10 \mathrm{~mm}$ towards the outside surface. The second hole was smaller and irregularty shaped, but it extended completely through the candle. A crack ran through both of the holes. The smaller hole showed evidence of dust penetration, indicating that there was flow through the smaller hole before it broke. 
Strength Tests - Four-point bend testing was done for both exposed and unexposed candles. There was a significant decrease in strength for the exposed samples. The strength degradation on the exposed samples was so pronounced that after bars were cut, the material appeared very weak and crumbly to the touch. In fact, the first set of bars failed prematurely, necessitating a different technique of surface preparation. Therefore, a second set of bars had a finish ground to 1 micron. This technique produces more consistent results. The test results are shown in Table 5.

Table 5. Four-point Bend Teet of Schumacher Candle Fliters

\begin{tabular}{||c|c|c|}
\hline \multicolumn{1}{|c|}{ Sample } & MPa, mean & Std. Dev \\
\hline Sample 1, unused & 12.0 & 0.987 \\
\hline Sample 2, unused & 14.1 & 1.107 \\
\hline Sample 3, unusi:d & 13.6 & 0.575 \\
\hline Sample 4, used & 5.1 & 0.626 \\
\hline
\end{tabular}

For the testing of the unused samples, eight bars per sample were tested. For the exposed candles, only six bars per sample were tested. The resulting decrease in strength for the exposed candles was more than 61 percent compared to the unused samples. Raw data for the tests are shown in Figure 20.

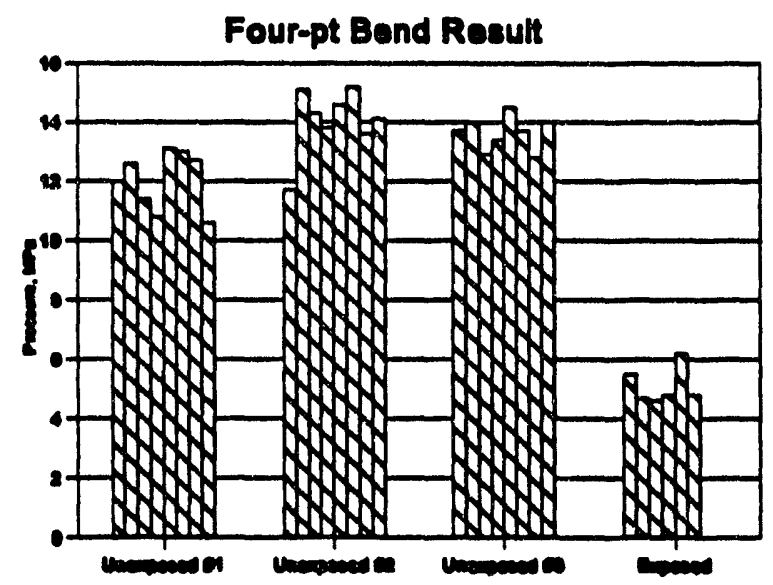

Figure 20. Four-point Bend Tests of Schumacher Dla-Schumalith Candles

EDX Results - EDX scans were produced on exposed and unexposed samples. The results are summarized in Table 6.

The exposed candles picked up a significant amount of calcium. The concentrations were quite large, and because of reactions with silica, may have caused strength degradation. High alkali levels over long exposure periods can cause chemical reactions to occur between the alumina/silicon carbide binder and the potassium. This in turn can change the coefficient of thermal expansion 
Table 6. EDX Scans of Schumacher Dla-Schumallth Candle Specimens

\begin{tabular}{|lrrrrr|}
\hline & \multicolumn{5}{c|}{ Welght Percent } \\
\cline { 2 - 6 } Element & \multicolumn{4}{c|}{ Unexposed } & \multicolumn{3}{c|}{ Exposed } \\
\cline { 2 - 7 } & Sample 1 & Sample 2 & Sample 3 & Sample 1 & Sample 2 \\
\hline $\mathrm{Ca}$ & 0.21 & 0.228 & 0.310 & 42.27 & 53.48 \\
$\mathrm{Al}$ & 9.98 & 10.05 & 10.07 & 2.53 & 1.68 \\
$\mathrm{Na}$ & 1.08 & 0.955 & 1.285 & - & - \\
$\mathrm{K}$ & 1.91 & 1.93 & 1.989 & - & - \\
$\mathrm{Si}$ & 85.17 & 85.34 & 84.68 & 12.72 & 1.75 \\
\hline
\end{tabular}

(CTE) as well as the thermal conductivity in the material. The change in thermal properties can cause cracking from thermal stresses due to pulse cleaning.

SEM Examinatton - SEM photographs of the exposed samples are shown in Figures 21 and 22. The photograph in Figure 21 was taken at 750 magnification and corresponds to EDX scan 1 (exposed). The fusion of grains can be seen in this photograph. The second photograph at 3000 magnification, shown in Figure 22, shows areas of apparent alkall fusion on the surface. Since the EDX analysis indicated high calcium, the apparent fused material is most likely calcium sulfate (CaSO4).

There is some evidence of microcracking in the 3000 power photograph. A silicon carbide grain can be seen having cracks running through it. This microcracking would have a significant effect on the material strength.

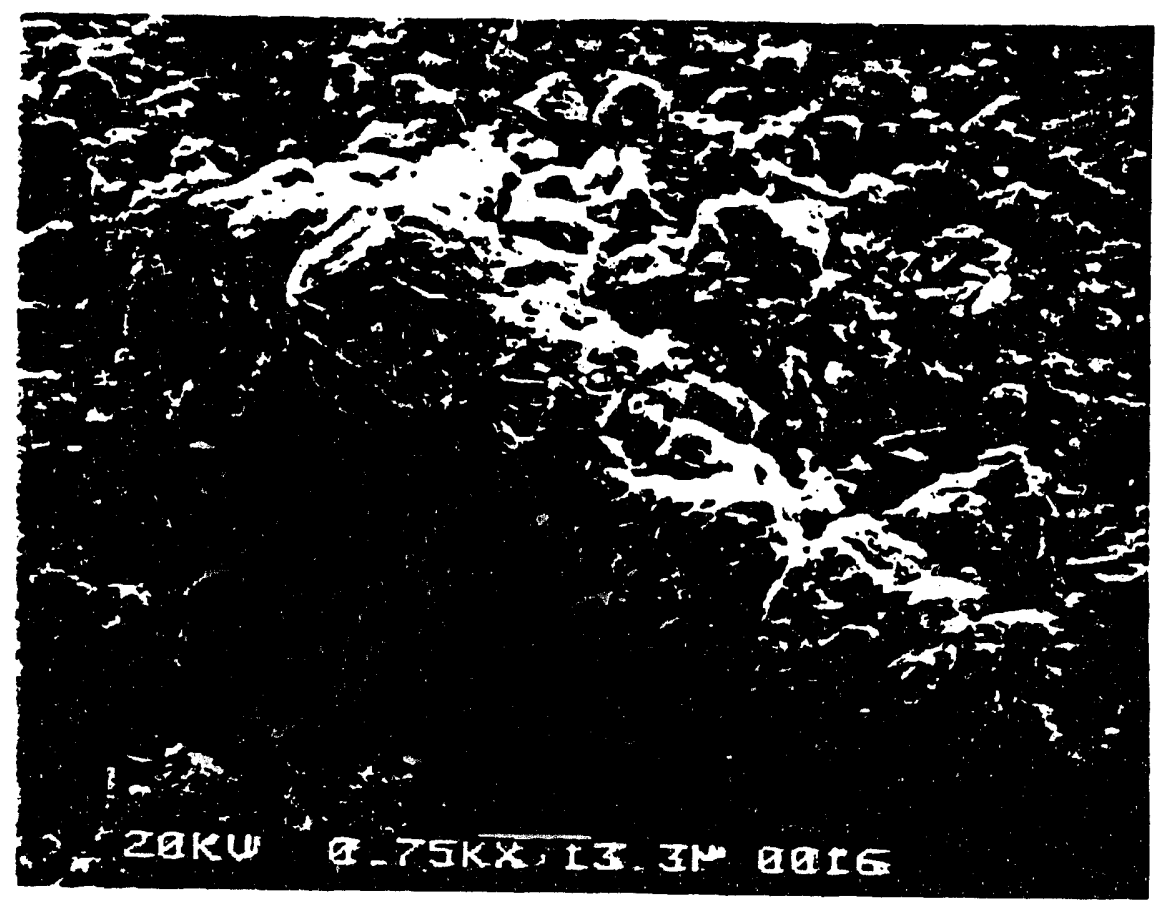

Figure 21. SEM Photograph of Exposed Dla-Schumalith Candle Filter 


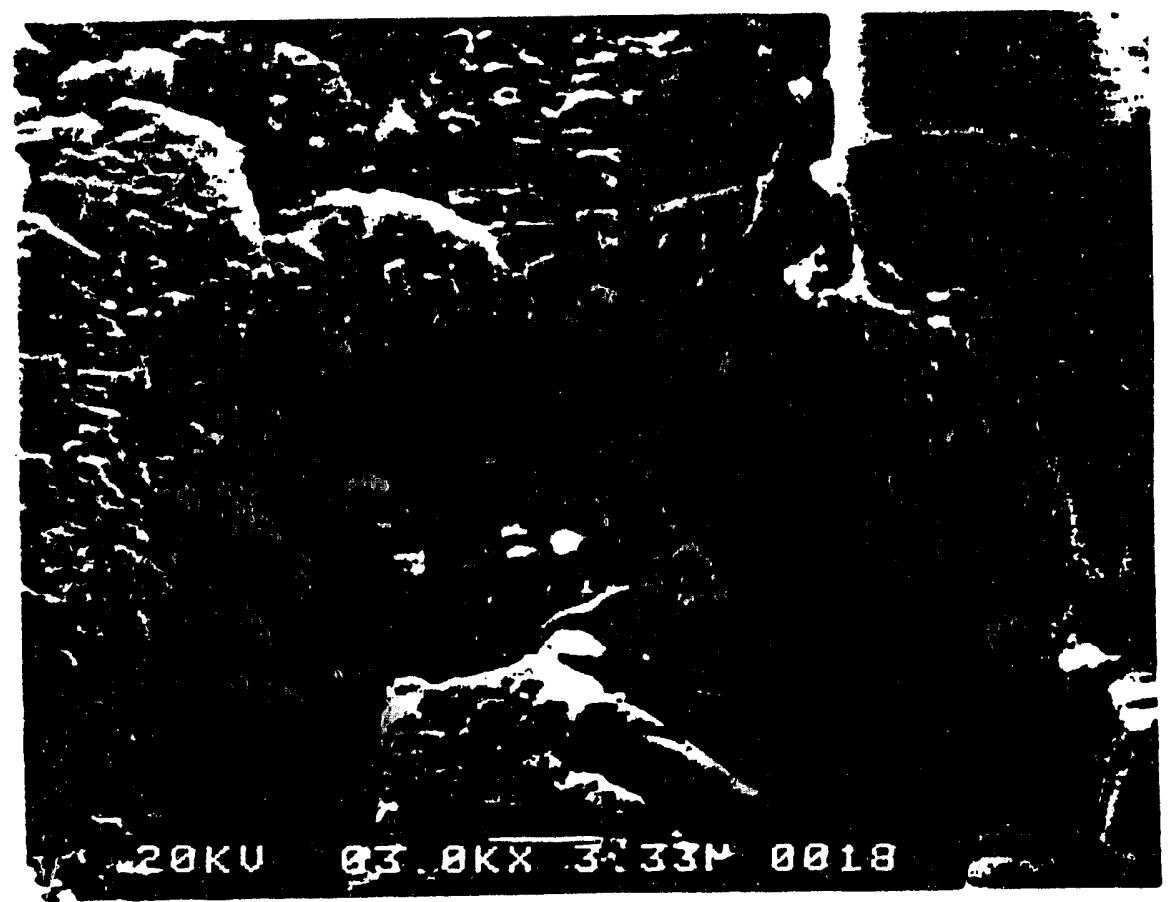

Figure 22. SEM Photograph of Exposed Dla-Schumallth Candle Flltor

XRD Analysis - XRD scans for the unexposed samples are shown in Figures 23-25. The exposed sample was also scanned; this scan appears in Figure 26. The plots are arranged with degrees 2theta on the abscissa. The ordinate reflects the count scale. The absolute count values are relatively unimportant here since relative peak heights are used to compare different compounds.

A number of silicon carbide phases were discovered to be present:

\begin{tabular}{|c|c|c|}
\hline & SiC: & $\begin{array}{l}22-1317 \\
\text { pisenite }-6 \mathrm{H}): 29-1131\end{array}$ \\
\hline & sic: & $29-1128$ \\
\hline & Alpha-SiC: & $22-1273$ \\
\hline & (SiC) 8F: & $\begin{array}{l}29-1129 \\
20-1316\end{array}$ \\
\hline & Beta-SiC: & $1-1119$ \\
\hline
\end{tabular}

Comparisons between the exposed and unexposed samples showed no major difference in the XRD scans.

As a result of the Acurex analysis, it was concluded that the holes in the candle wall for this particular failed candle were the cause of failure. At this point, it is not known whether the holes occurred during testing or whether they were inherent defects. There were significant changes in strength due to exposure. The candle strength decreased approximately 60 percent from the asreceived condition, most probable due to microcracking of the candle structure. The cause of the microcracking is not known at this time. In addition, since the parts of the candle that were examined came from the parts that had fallen to the bottom of the vessel, impact might have caused or contributed to the cracking. 


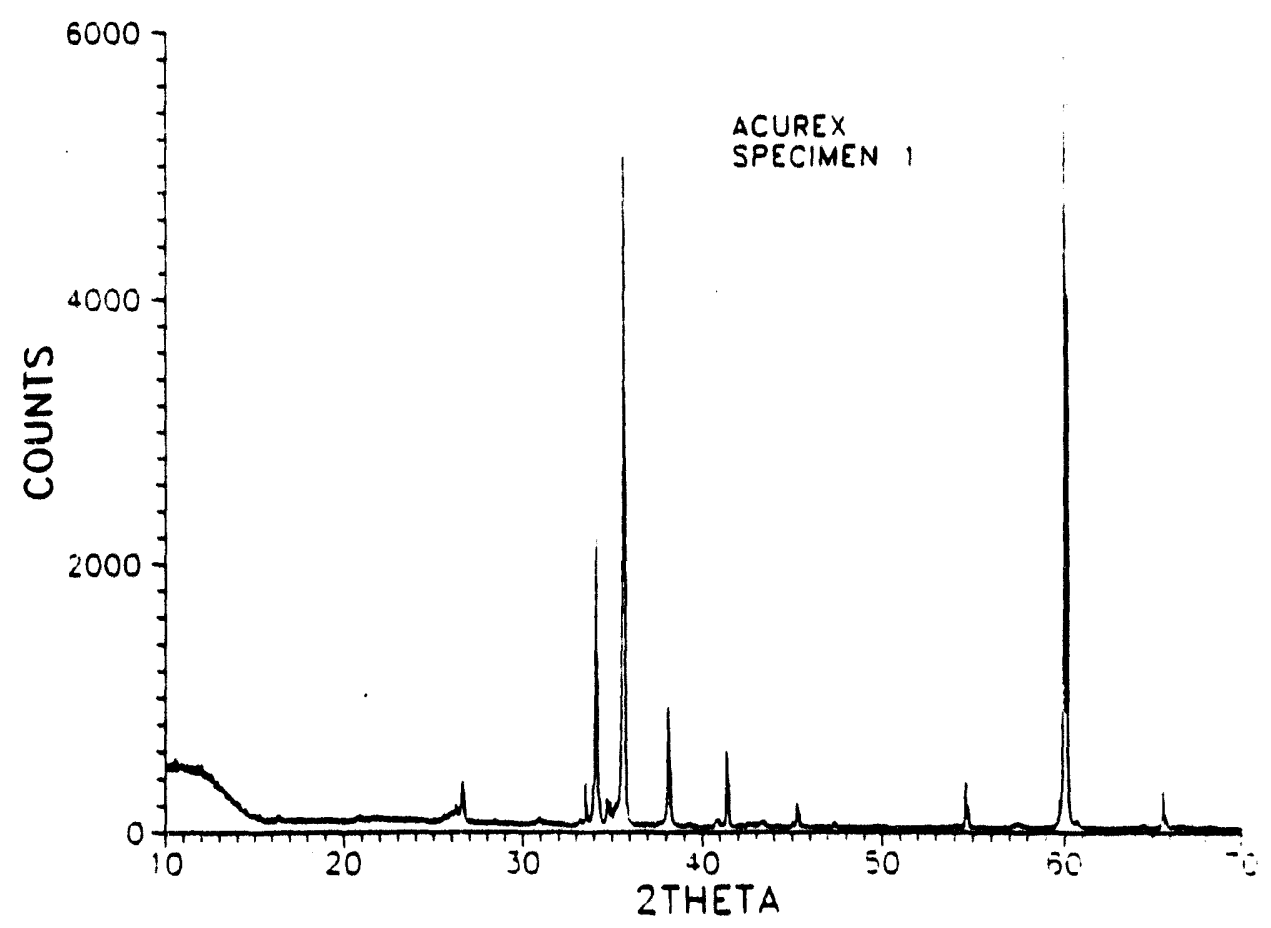

Figure 23. X-ray Diffraction Patter for Now Schumacher Candle, Specimen *1

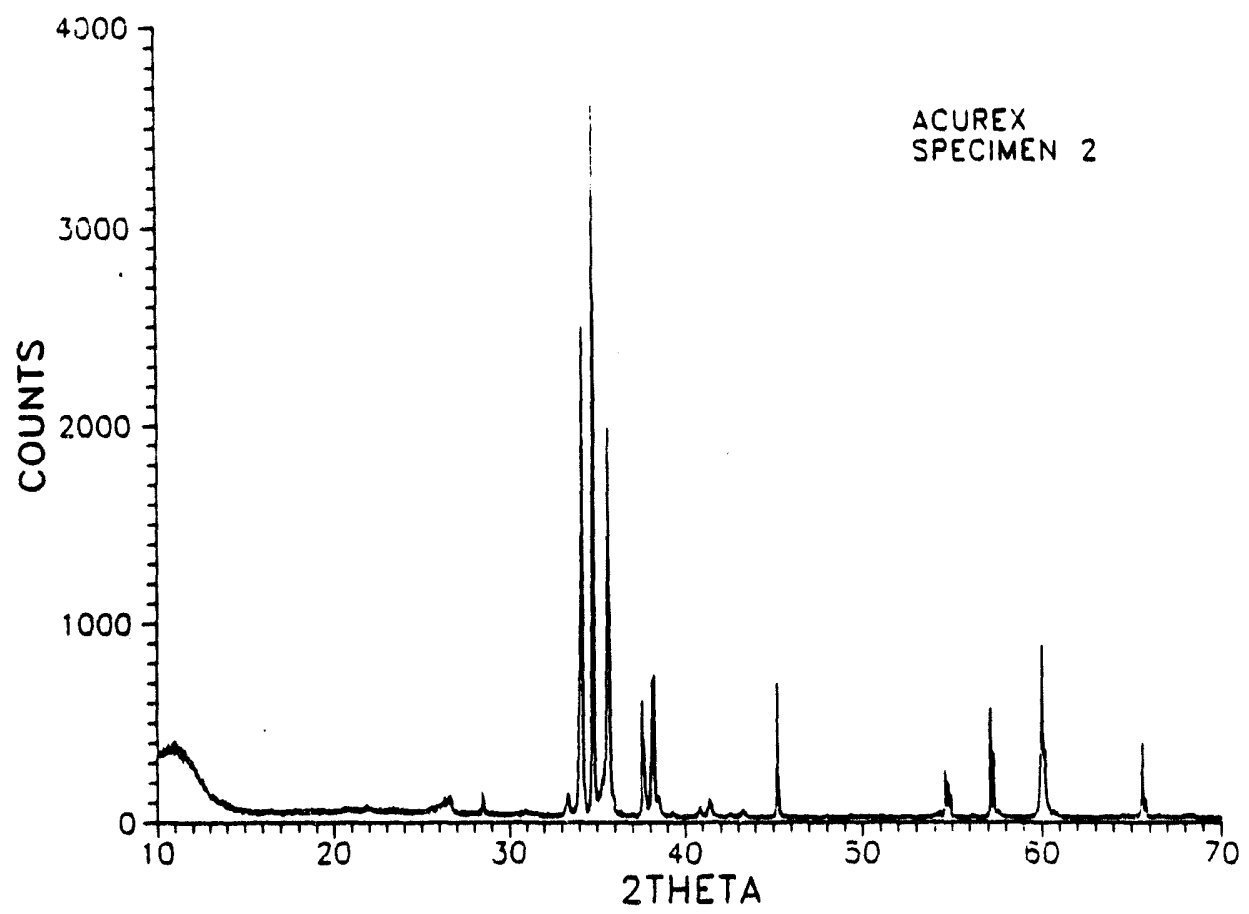

Figure 24. X-ray Diffraction Patter for Now Schumacher Candle, Specimen *2 $^{2}$ 


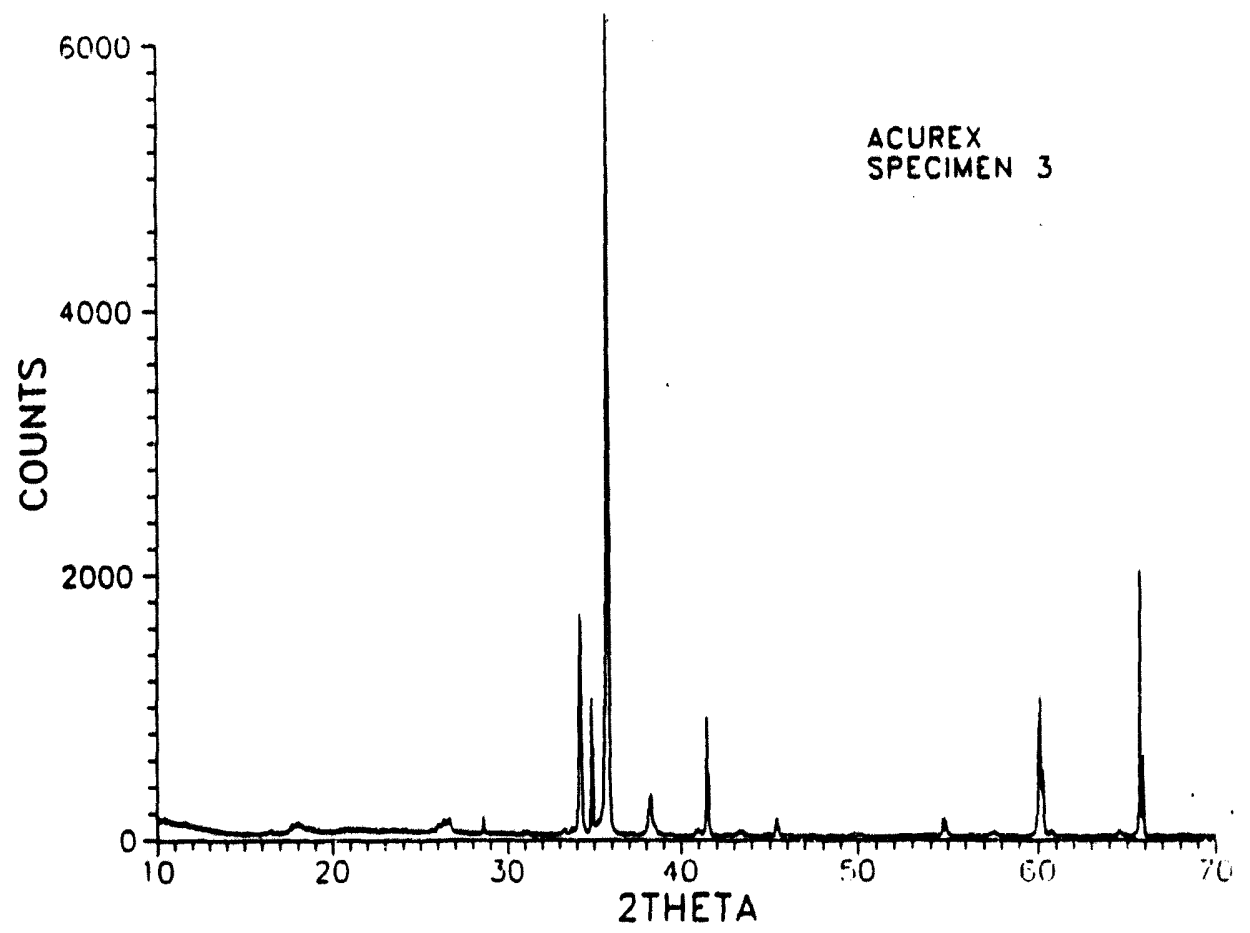

Flgure 25 X-ray Diffraction Pattern for Now Schumachor Candle, Spocimen *3

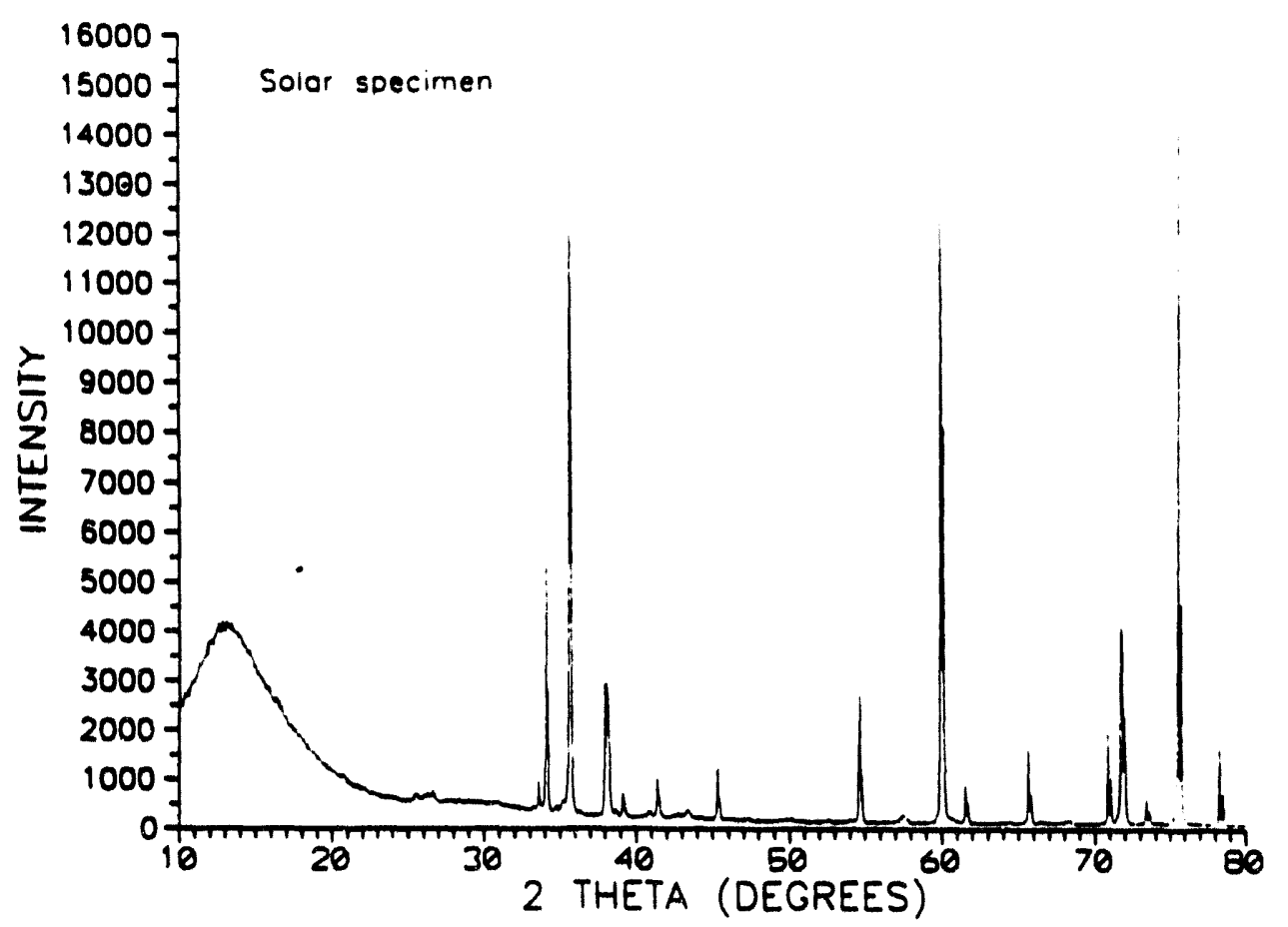

Flgure 26 X-ray Diffractlon Pattem for Expoeed Schumachor Candle 
Vibrational phenomenon was a cause listed on the fault tree. Vibration data were collected for an unexposed and an exposed candle. In addition, high speed dynamic pressure Klatter preasure transducer was mounted in the filter vessel and test data were collected to determine what frequencles were being generated by the combustor.

Two candles were taken to Solars Sky Park vibration facillty. One of the candles was exposed during the extended test, but was stll intact. The other candle was an unexposed, virgin Schumacher Dla-Schumalith. Frequenoy response curves were obtained for each candle.

The frequency reaponses curves were obtained by placing the candle on two foam blocks to simulate a freo-free system. An acceleromoter was mounted on the flange of the virgin candle and on the Hasteiloy-X cup for the exposed candle. An Impedance hammer was used to strike the candle in a fixed location five times. A mioroprocessor averaged the data. Each candle was struck with the hammer in locations that inctuded both ends, and at 15, 30 and 45 inches from the top flange of the candle.

The data are summarized in Flgure 27 for the unexposed or virgin candle, and in Figure 28 for the exposed candle. The virgin candies showed much stronger responses whereas the exposed candle exhiblted some dampening, perhaps by the presence of dust in the interatices of the candle. The most active frequencies for the virgin candle were in the $200-400 \mathrm{~Hz}$ region. The lowest frequency at approximately $7 \mathrm{~Hz}$, responded at about 1.5 times the excitation; the most active response was at $414 \mathrm{~Hz}$ and at the flange end of the candle where $32.2 \mathrm{tmes}$ the excitation was observed. These data are also dlsplayed in Table 7 for both unexposed and exposed candles.

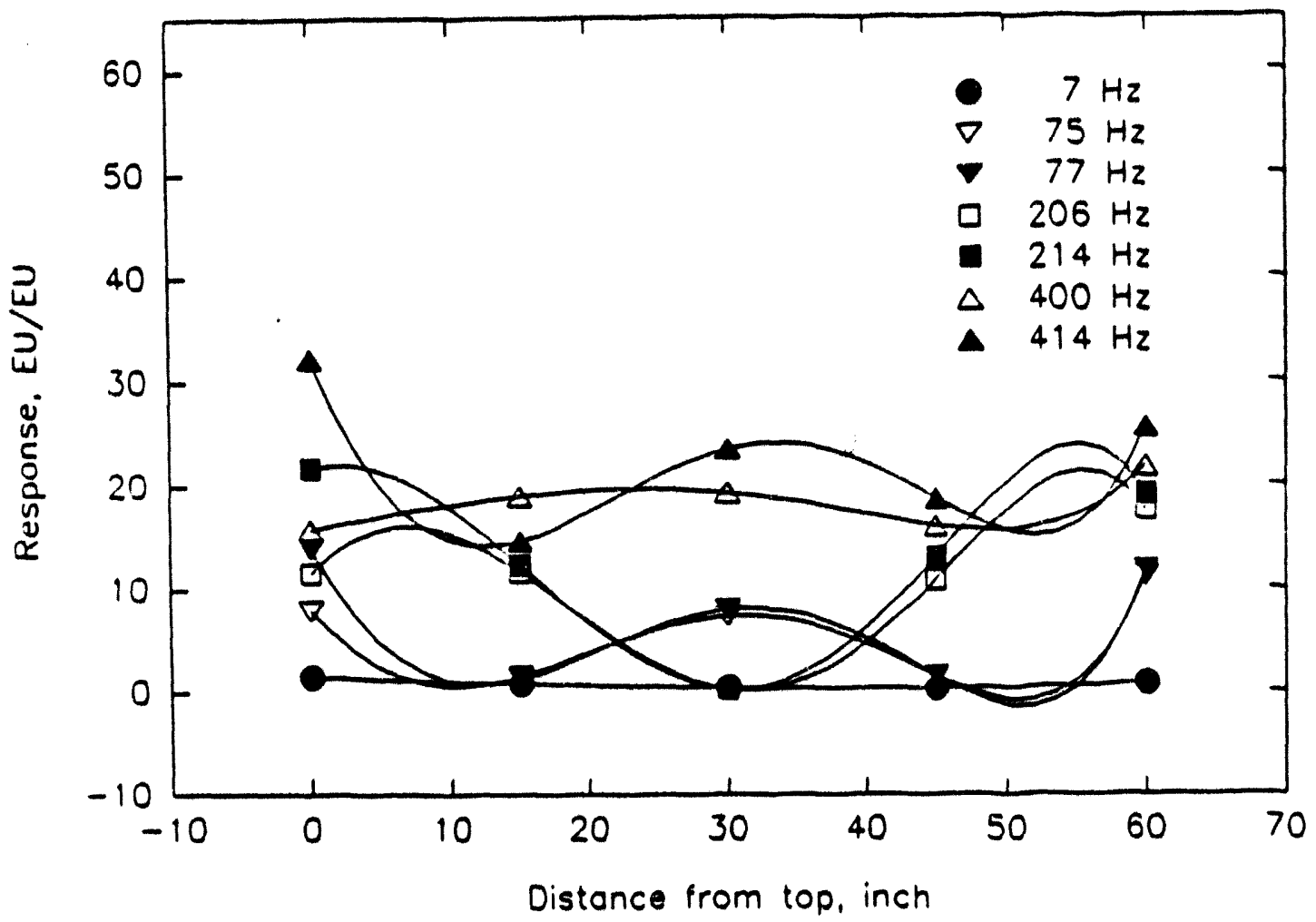

Figure 27. Frequency Responce Curves for Unexposed candlo 


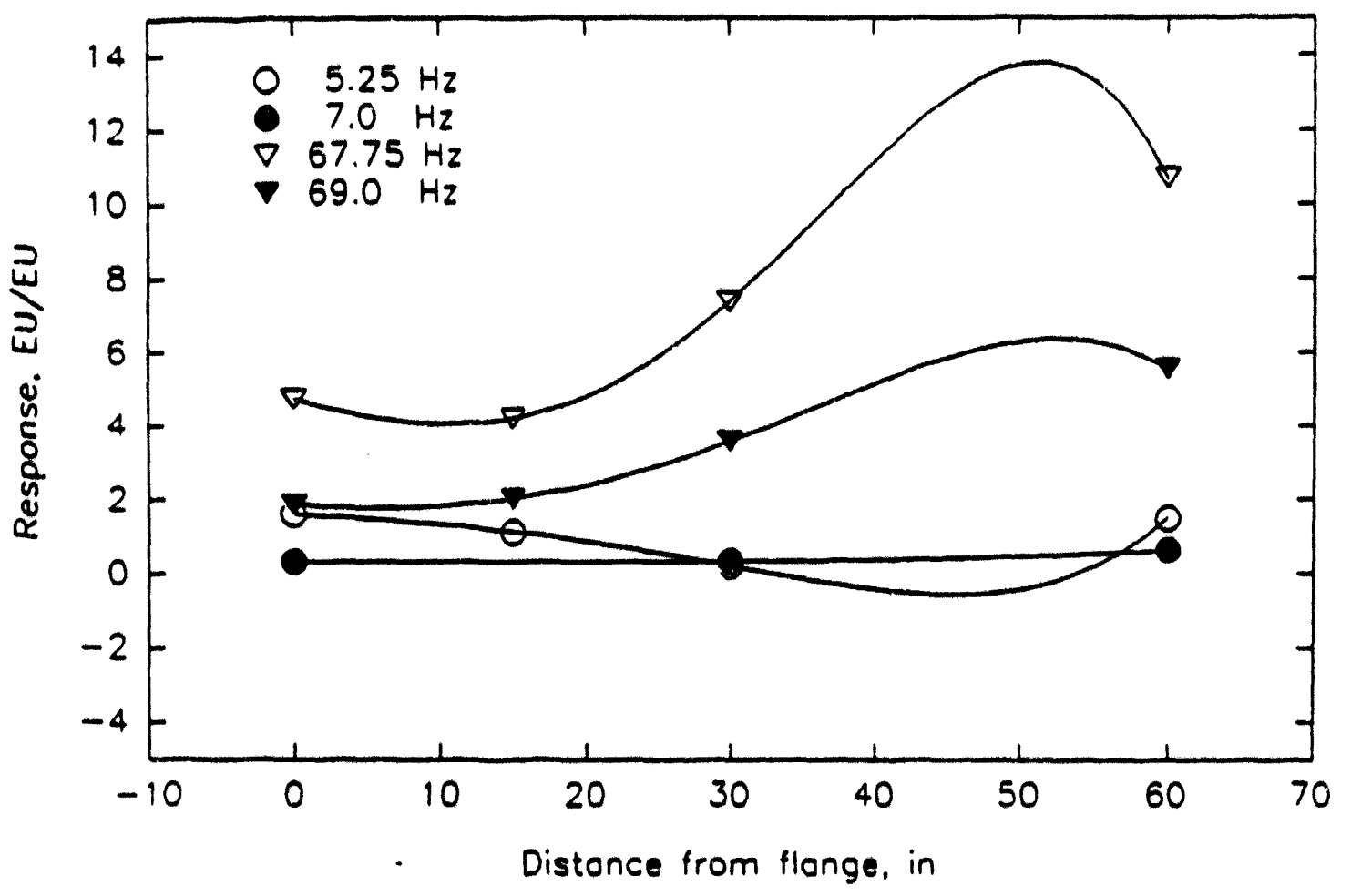

Figure 28. Frequeney Responee Curves for Exposed Candles

A test was conducted at the IBSTF with diesel fuel 2 to determined trequency response characteristics of the system. A fast-response Klatler pressure transducer was installed in the filter vessel using one of the window ports. The transducer housing was cooled; this permitted measurements to be taken at fairty high temperatures. The signal from the plezoelectric transducer was amplified using a charge amplifier. The amplified signal was then input to a Spectral Dynamics spectrum analyzer. All nolse was basically low frequency and below about $100 \mathrm{~Hz}$. In general, the pressure fluctuations were about \pm 0.1 psid. A graph of a typical trace is shown in Figure 29. While the pressure fluctuations were negligible in general, fluctuations as high as \pm 1 psi were observed, coincident with an airplane taking off. The only significant datum from this test were the increased pressure fluctuations that were observed when planes took off. For this reason, a secondary experiment was conducted to observed, solely, the effect of airport-generated noise on the strength of rigidly and non-rigidly mounted candles. Based on strength measurements, there was no measurable effect.

Another experiment was conducted with an accelerometer mounted on a candle in the Hot End Simulation Rig and with a microphone installed in the filter vessel. The experiment was, by necessity, conducted at atmospheric pressure and amblent temperature. However, at a face velocity of $6 \mathrm{Htmin}$, there was considerable low frequency noise, particularty below $20 \mathrm{~Hz}$. A level of $104 \mathrm{~dB}$ was measured at about $10 \mathrm{~Hz}$. There was not much occurring above $20 \mathrm{~Hz}$, with the exception of some noise about $40 \mathrm{~Hz}$. It was pretty much lower intensity white noise above that with no pronounced specific frequencles. The candle manifested responses around $55 \mathrm{~Hz}$, and two peaks near $120 \mathrm{~Hz}$; one was about $115 \mathrm{~Hz}$, the other about $124 \mathrm{~Hz}$. From this test, it did not appear that system noise was causing the candles to resonate. 
Table 7. Reconant Frequenoy Data for Virgin and Exposed Candlee

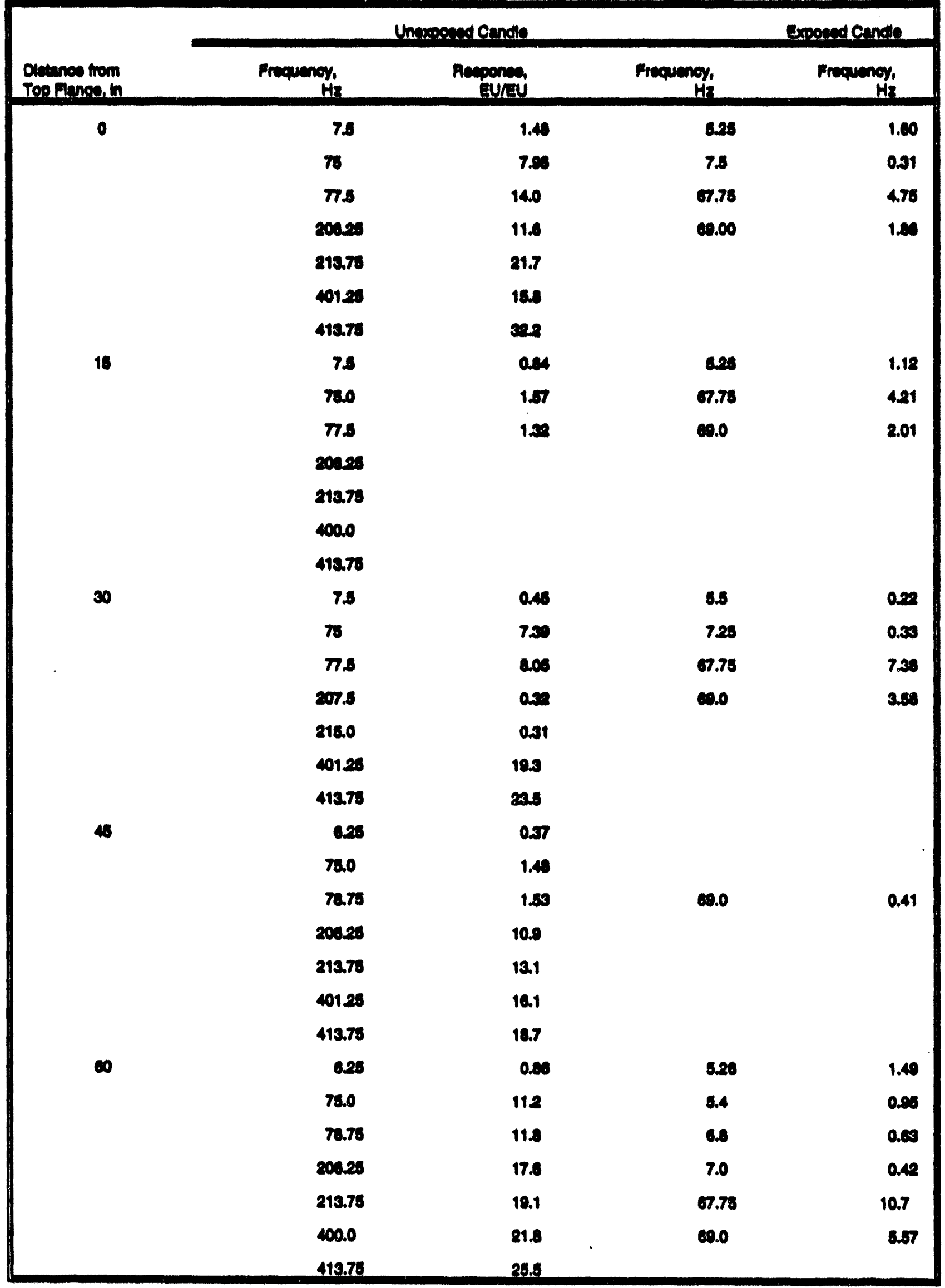




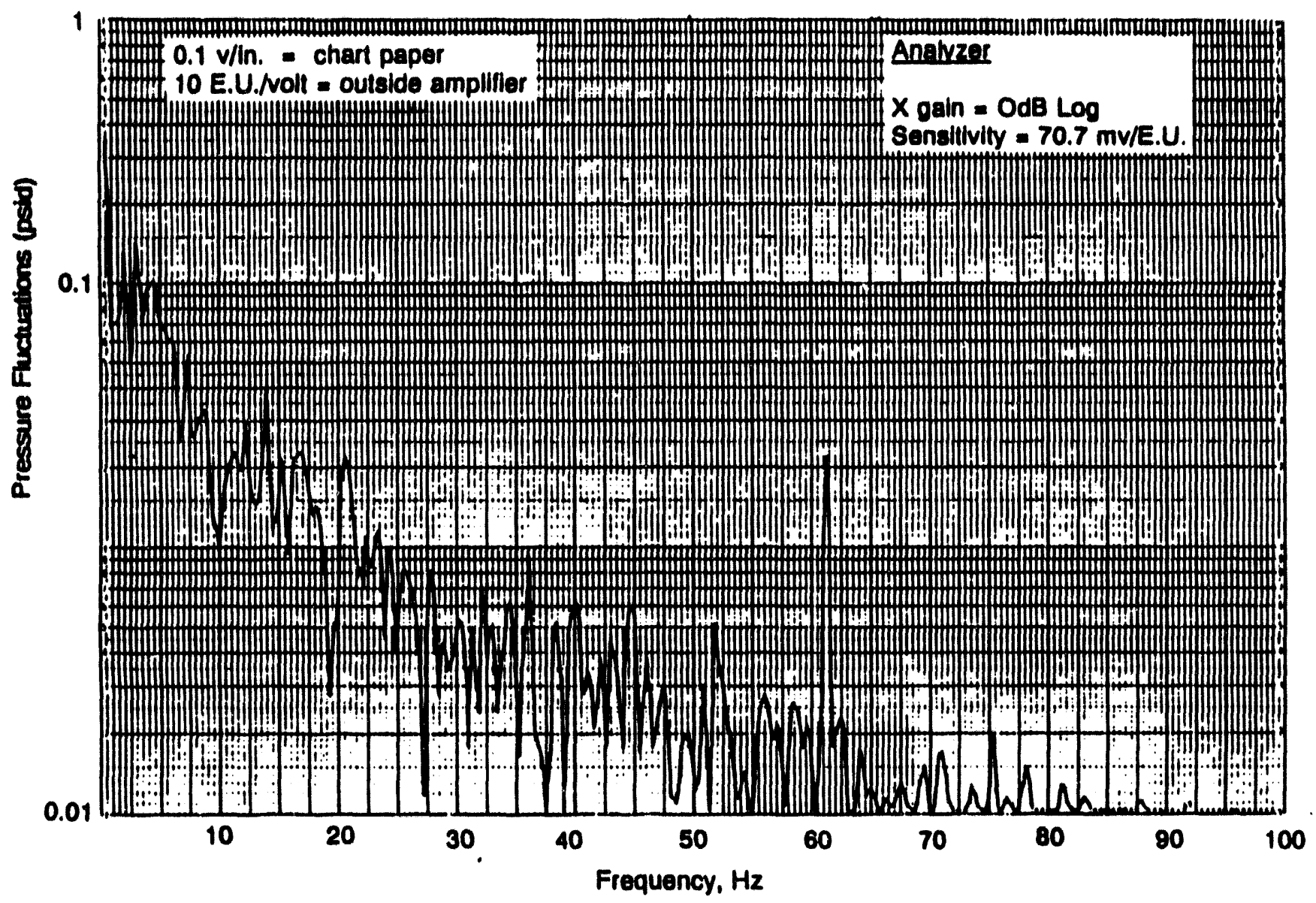

Figure 29. Frequeney Characterlaties of the IBSTF

The effect of the cooled tubesheet was of some concern. In the design phase of the barrier filter system, an ANSYS heat transfer analysis was performed to determine the types of temperature gradients the candle might experience. Elfectvely, the axial temperature gradients were discovered to occur over the first couple inches of the candle and were not at the point of failure. The location of the failures occurred at a point where the candle was already close to the gas stream temperature.

Concluelone, Acurex testing - Visual examination of the broken sections of the candle led to the conclusion that the holes in the candle wall were the cause of failure. It was impossible to conclude whether the holes occurred during testing or whether they were manufacturing defects.

The analyses indicate that there were significant changes to the cendles from exposure. The candle strength decreased approximately 60 percent from the as-recelved condition. The reduction in strength was likely due to the microcracking of the candle structure. What caused the microcracking was impossible to determine. The broken candle that was examined came from parts that had fallen to the bottom of the filter vessel. That alone could have caused the cracking.

The candle had significant amounts of calctum on the surface. Phase diagrams for the calcium-sillica systems indicate that there can be formation of calcium silicates at temperatures as low as $600^{\circ} \mathrm{C}$. The short exposure time and the lack of difference in the XFD patterns between exposed and unexposed candles indicates that this was a remote possibility. 


\section{Rofreotron Candlo Filtor Toate}

The Refractron candle filters were tested in beginning in Octobor 1991 and commencing in April 1992 in the IBSTF. These candle filtere accumulated more time than the Schumacher DiaSchumalith candies. The accumulated time on diesel fuel 12 was 26.3 hours and on a Kentucky $4 A$ (Blue Com and Elkhom) coal water mixture, the total exposure time 27.4 hours. There were approximately 25 one second cleaning pulses during this exposure time.

The Refractron candle filtere were examined by Acurex Corporation under a separate contract. The objective of the work was to analyze the Rofrectron $50 / 5$ with 505 binder candles and the Refractron 50/5 with 442-T binder candles, both of which were exposed at Solar. Unused candles were analyzed as well to provide the necessary baseline from which to compare the exposed candles. The purpose of analysis was to determine the effects of exposure on both types of Potractron candles. All candies were exposed to the samo operating conditions. Detailed results of this study la reported in detall elsewhere (ref. Sawyer, 1993).

The test procecture included three types of teets on both exposed and unexposed candles from each candle type (505 binder and 442-T binder). These tests were:

- C-ring tension and compression tests at room temperature and at $980^{\circ} \mathrm{C}$.

- X-Ray Diffraction (XRD)

- Scanning Electron Microscopy (SEM) and Energy Dispersive X-Ray (EDX) analysis.

Four candle test conditions (with three candles tested for each condition) were examined:

- Exposed Refractron 50/5 with 505 binder

- Unexposed Refractron 50/5 with 505 binder

- Exposed Refractron 50/5 with 442-T binder

- Unexposed Refractron 50/5 with 442-T binder

The candles were exposed in the Solar IBSTF (Configuration 1 and 2) for 27.4 hours with a Kentucky $4 A$ (Blue Gem and Elkhom) coal water slurry fuel. The first 10 hours were Configuration l; the remaining hours were carried out with Configuration II. The gas emissions, corrected to $15 \% 02$, were 9-12 ppm NO, $3-5 \mathrm{ppm}$ of $\mathrm{CO}$, and 60-120 ppm of $\mathrm{SO}_{2}$. There were approximately 25 1second cleaning pulses in the testing hiatory of the used candles. The testing was done over a period of several months with the first test taking place in October 1991. The final testing occurred in April, 1992. A total of three tests with coal slurry were performed, with the first being of 10 hours duration in October. The final two tests occurred in March and April of 1992.

C-Fing Test Description-C-Aing testing was selected as the primary mechanical strength testing method. C-rings were obtained by sectloning 0.75 -inch wide rings out of the candles and then making a single longitudinal slit (perpendicular to the sectioning direction) on one side of the ring (Figure 30). Cring testing leaves the candle surfaces unaffected, including both inner bore and the outer tube surface. Thus, any surface flaws that are examined are the result of exposure, not sample preparation.

C-ring specimens are loaded under tension and compression. Under tension, the inner surface of the candle at a point opposite the slit experiences the maximum tensile stress, while the outer surface experiences the maximum compressive stress. Under compression, the outside surface opposite the slit bears the maximum tenalle stress. Ceramics are much stronger under compressive than tensile stresses. Therefore, the fallure/racture will originate at the surface with the maximum 


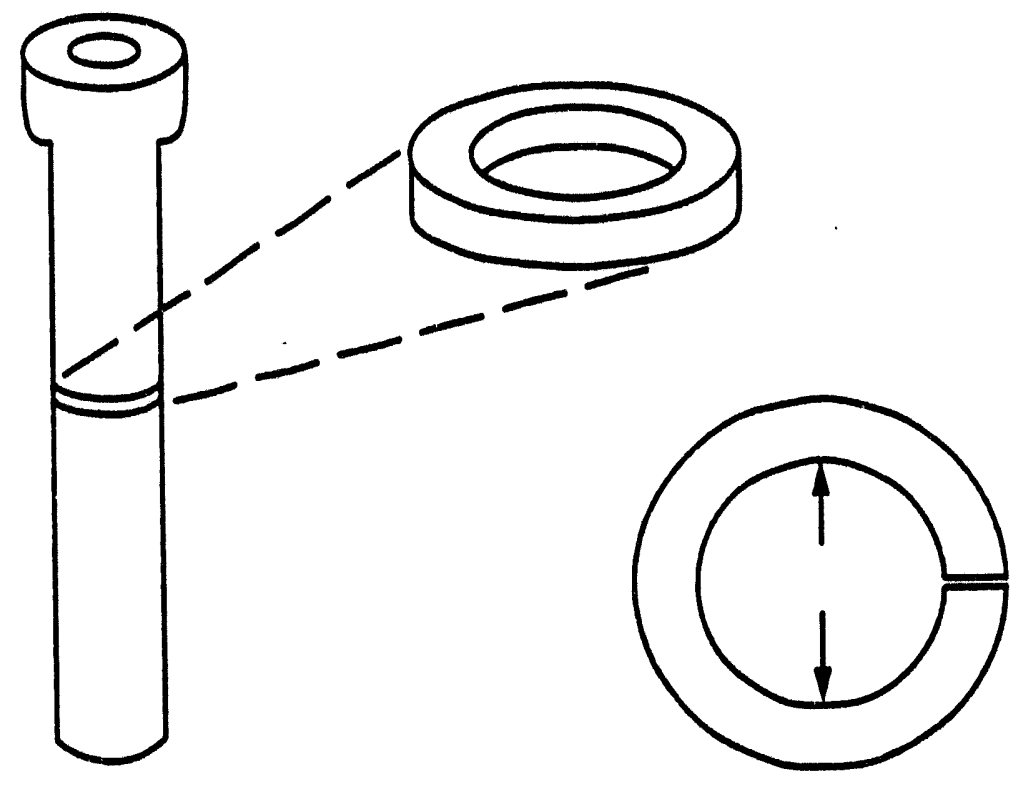

TENSION ID in tension

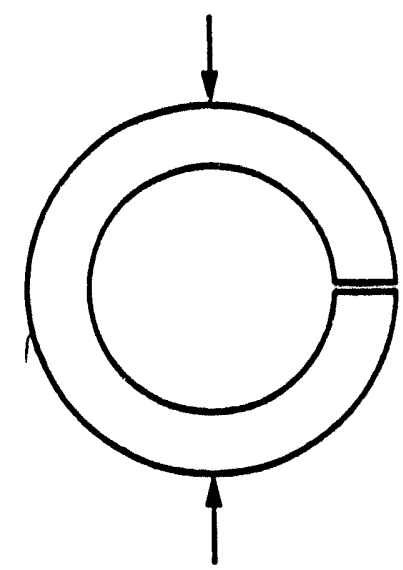

COMPRESSION $O D$ in tension

Figure 30. C-Ring Teat Specimen

tensile stress. This phenomenon permits a particular surface, either inner or outer, to be studied for its strength degradation under different environmental conditions.

Acurex used a Tinius Olsen Four-Screw Electomatic $(120,000-1 \mathrm{~b}$ maximum) universal testing machine for its $\mathrm{C}$-ring tests. The load readings were taken from a separate load cell (Sensotec load cell Model No. 41/571-06).

Each of the four candle/test conditions (12 candles total) was tested under both tension and compression, at room temperature and at $980^{\circ} \mathrm{C}$.

$X$-Ray Diffraction Test Description - In XRD analysis, a small cross-section of the candle is ground to a fine homogeneous powder. Each particle of the powder is a tiny crystal (or a collection of crystals) oriented at random with respect to the incident $x$-ray. The characteristic diffraction peaks and intensities that are produced and detected can be compared to known standards, permitting identfication of the crystal phases. A Suenebs diffractometer was used in the XRD analysis of the Refractron candles.

SEMEDX Analysis - The SEM is used to visually examine surfaces at magnifications higher than those achievable by optical microscopes. To obtain an image, the specimen is scanned by an incident electron beam and the radiation that escapes is collected and processed. The secondary electron images is sued for micrographs because of the considerable depth-of-field, which gives 3-dimensional quality to rough specimens. 
An EDX detector is used in conjunction with an SEM to provide quanttative analysis of specific areas being viewed. This technique permits determination of the surface and subsurface elemental composition. The EDX detector that was used did not detect elements having atomic weights less than 23 (sodium). Therefore, carbon, oxygen, and nitrogen were not determined.

The two types of Refractron candles, the 505 binder and the 442-T binder, were tested simultaneously. Seven 505 binder candles and seven 442-T binder candles were used in the test. Their location in the filter vessel is shown in Figure 31. A numbering system was set up to identify the candle being tested according to where it was located in the filter vessel. These numbers are shown in the flgure for the candles tested by Acurex.

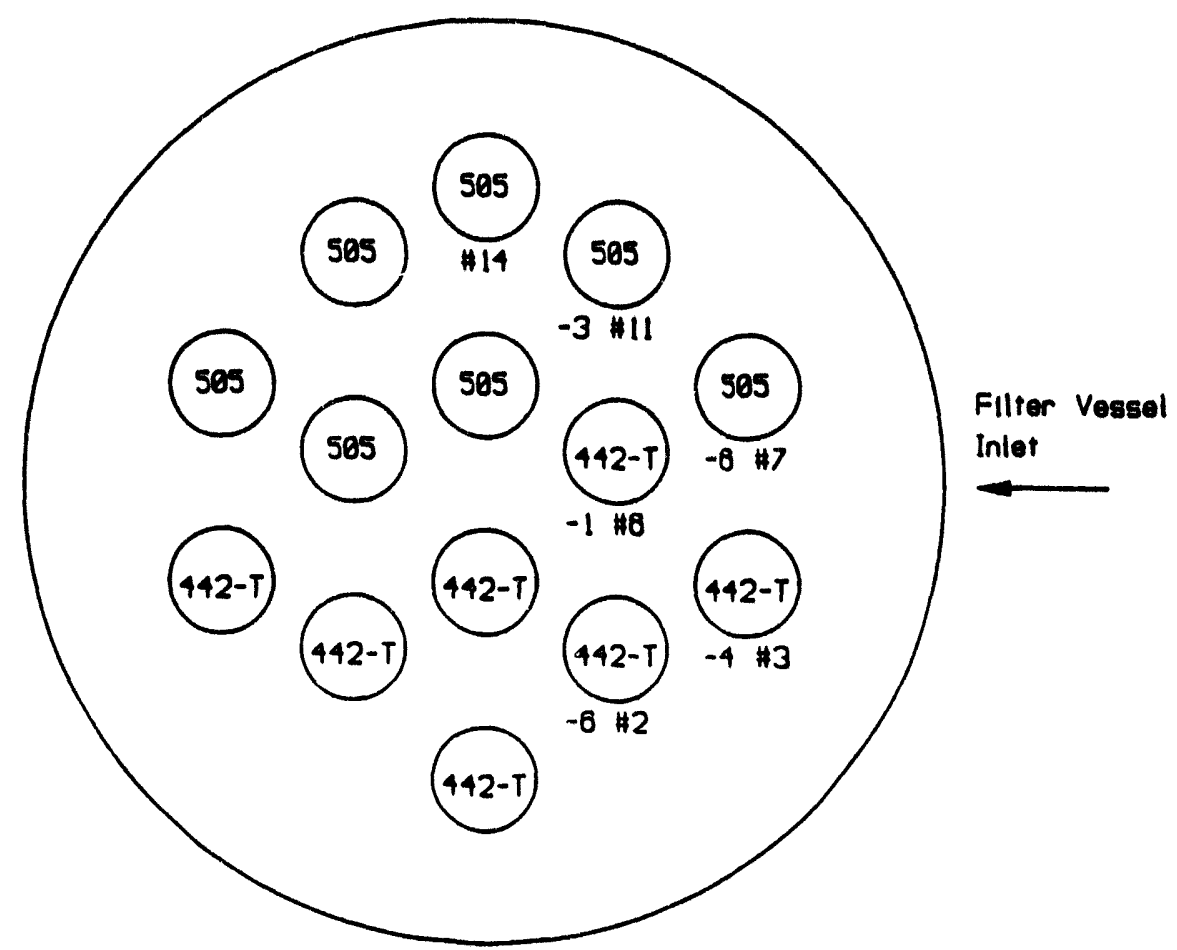

Figure 31. Location of Refractron Candles Filters in the IBSTF Filter Vesed

The C-ring test data are shown in Table 8 and in Figures 32 and 33.

$X$-ray Diffraction Analysis - XRD of all of the Refractron candles indicated the presence of silicon carbide (SIC) as the major constituent, as would be expected since 90 percent of the candle material is comprised of silicon carbide grains. It was hoped that phase changes and crystalline changes could be detected when a candle was exposed to the DCFT environment. Unfortunately, the data are inconclusive in this regard as compounds found in the unused candles were found in one of the used candles and vice versa. For example, KAISIO, was detected in all of the unused 442-T binder candles and in one of the three used candles. These data are summarized in Table 9.

It would have been erroneous to test only one candle from each test condition, as such might have led to the false conclusion that some compounds present in one test condition might not have been present in another. In reality, as evident from the data in Table 9, definite conclusions cannot be drawn regarding the exclusion of a given compound in a candle. 
Table 8. C-Ring Test Results on Refractron 50/5 Candle Filters

\begin{tabular}{|c|c|c|c|c|}
\hline \multirow[b]{2}{*}{$\begin{array}{l}\text { Refractron } 50 / 5 \\
\text { Candle Description }\end{array}$} & \multicolumn{2}{|c|}{ Tension } & \multicolumn{2}{|c|}{ Compression } \\
\hline & $\begin{array}{l}\text { Room Temp. } \\
\text { Strees, MPa }\end{array}$ & $\begin{array}{c}980^{\circ} \mathrm{C} \text { Stress, } \\
\mathrm{MPa} \\
\end{array}$ & $\begin{array}{l}\text { Room Temp. } \\
\text { Stress, MPa }\end{array}$ & $\begin{array}{c}980^{\circ} \mathrm{C} \text { Strees, } \\
\mathrm{MPa} \\
\end{array}$ \\
\hline $\begin{array}{l}505 \text { binder, used } \\
\text { Candle \#1 } \\
\text { Candle \#2 } \\
\text { Candle \#3 }\end{array}$ & $\begin{array}{r}15.25 \pm 1.34 \\
16.18 \pm 0.41 \\
15.92 \pm 0.68 \\
\end{array}$ & $\begin{array}{l}19.33 \pm 1.70 \\
15.64 \pm 1.98 \\
17.46 \pm 1.08 \\
\end{array}$ & $\begin{array}{l}18.12 \pm 2.10 \\
21.83 \pm 1.89 \\
18.33 \pm 2.13 \\
\end{array}$ & $\begin{array}{l}16.82 \pm 1.36 \\
12.45 \pm 1.92 \\
15.06 \pm 0.72 \\
\end{array}$ \\
\hline Average 505 unused & $15.79 \pm 0.92$ & $17.48 \pm 2.17$ & $19.43 \pm 2.58$ & $14.78 \pm 2.27$ \\
\hline $\begin{array}{l}505 \text { binder, used: } \\
\text { Candle *1 } \\
\text { Candle *2 } \\
\text { Candle *3 }\end{array}$ & $\begin{array}{l}9.63 \pm 1.59 \\
10.00 \pm 1.35 \\
10.72 \pm 2.92 \\
\end{array}$ & $\begin{array}{l}7.59 \pm 1.79 \\
7.98 \pm 1.79 \\
7.20 \pm 1.55\end{array}$ & $\begin{array}{l}10.72 \pm 3.56 \\
11.57 \pm 1.66 \\
12.37 \pm 3.11\end{array}$ & $\begin{array}{l}4.42 \pm 0.91 \\
5.89 \pm 0.84 \\
4.78 \pm 0.92\end{array}$ \\
\hline Average 505 used & $10.12 \pm 1.97$ & $7.59 \pm 1.42$ & $11.56 \pm 2.77$ & $5.03 \pm 1.05$ \\
\hline $\begin{array}{l}\text { 442-T binder, unused } \\
\text { Candle \#1 } \\
\text { Candle \#2 } \\
\text { Candle \#3 }\end{array}$ & $\begin{array}{l}20.30 \pm 0.80 \\
17.23 \pm 2.17 \\
18.96 \pm 1.52 \\
\end{array}$ & $\begin{array}{l}11.44 \pm 2.04 \\
15.07 \pm 1.03 \\
15.96 \pm 0.48 \\
\end{array}$ & $\begin{array}{l}20.75 \pm 1.75 \\
16.91 \pm 4.39 \\
14.39 \pm 1.11 \\
\end{array}$ & $\begin{array}{l}10.17 \pm 0.36 \\
11.15 \pm 0.47 \\
12.16 \pm 1.68 \\
\end{array}$ \\
\hline Average 442-T used & $18.94 \pm 1.93$ & $14.15 \pm 2.38$ & $17.61 \pm 3.72$ & $11.16 \pm 1.27$ \\
\hline $\begin{array}{l}\text { 442-T binder, used } \\
\text { Candle \#1 } \\
\text { Candle \#2 } \\
\text { Candle \#3 }\end{array}$ & $\begin{array}{l}15.40 \pm 1.01 \\
16.97 \pm 1.37 \\
14.76 \pm 0.79 \\
\end{array}$ & $\begin{array}{l}19.23 \pm 2.81 \\
23.46 \pm 2.80 \\
21.14 \pm 1.30 \\
\end{array}$ & $\begin{array}{l}13.74 \pm 0.64 \\
12.37 \pm 1.35 \\
11.69 \pm 0.43 \\
\end{array}$ & $\begin{array}{l}14.61 \pm 1.24 \\
17.55 \pm 1.62 \\
13.18 \pm 1.30 \\
\end{array}$ \\
\hline Average 442-T used & $15.71 \pm 1.39$ & $21.28 \pm 2.86$ & $12.60 \pm 1.121$ & $15.11 \pm 2.28$ \\
\hline
\end{tabular}




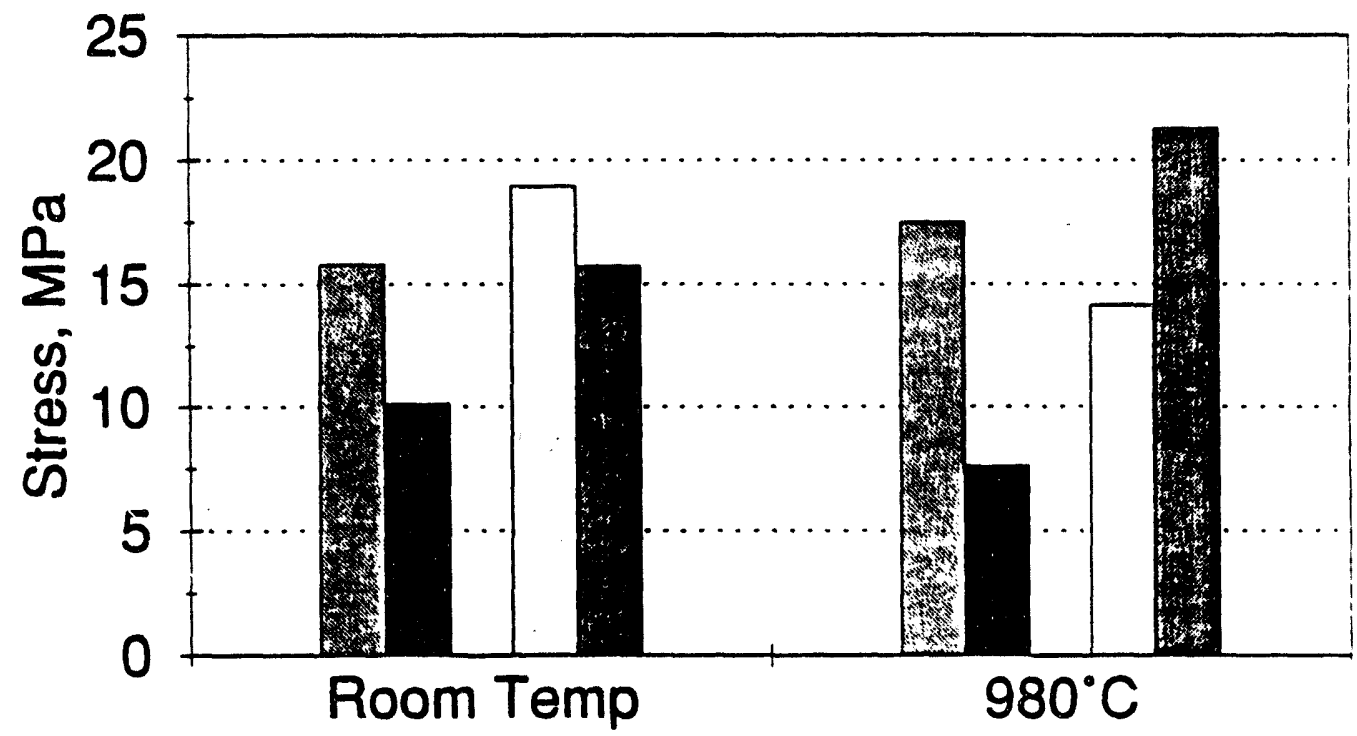

Unused 505 Used 505

$\square$ Unused 442-T Used 442-T

Figure 32. C-Ring Tenslon Tests of Refractron Candles

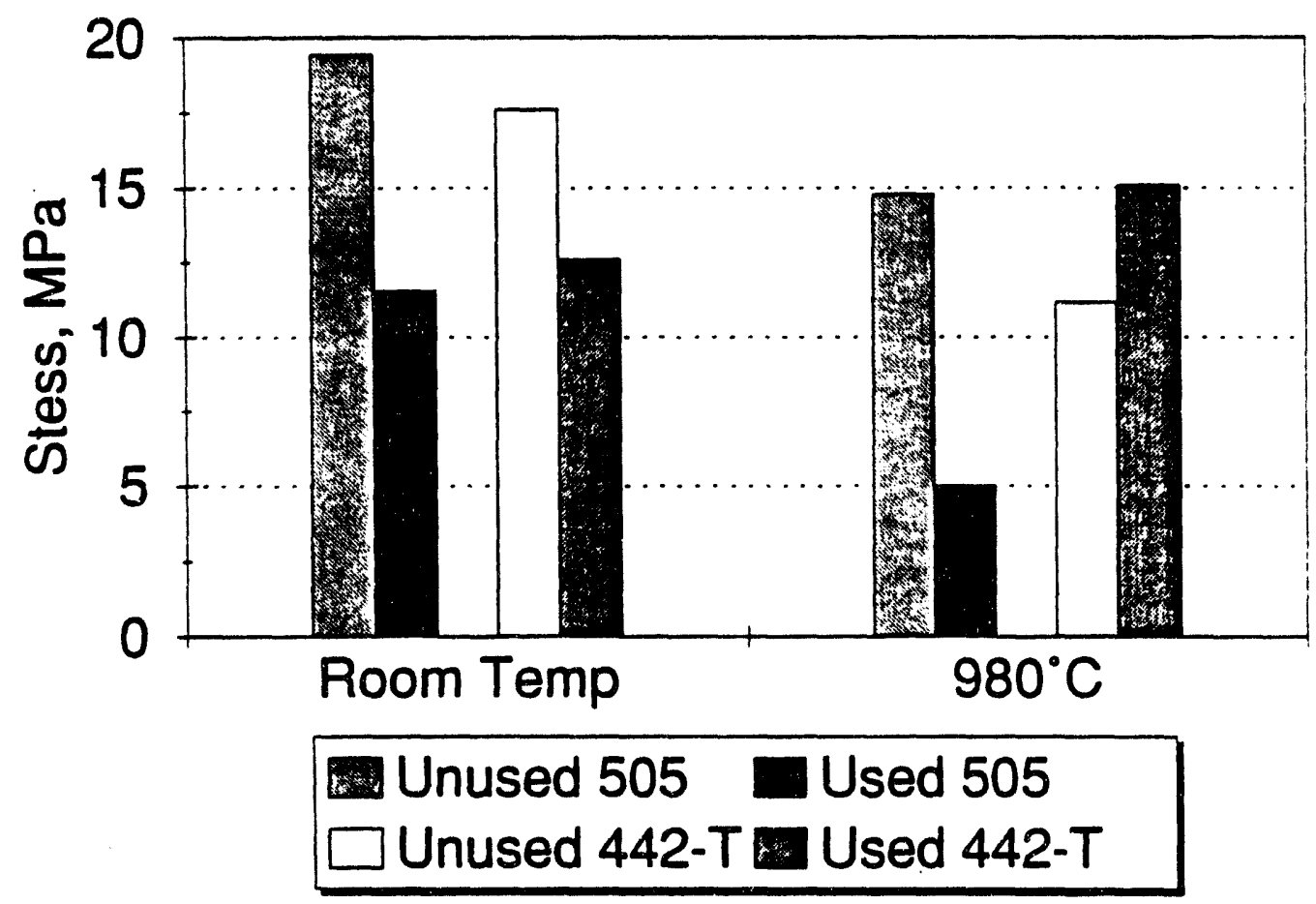

Figure 33. C-Aing Compression Tests of Refraction Candles 
Table 9. X-ray Diffraction Test Summary

\begin{tabular}{|c|c|c|c|c|}
\hline \multirow{2}{*}{ Refractron 50/5 } & \multicolumn{4}{|c|}{ Compounds Detected ( $V$ indicates detected) } \\
\hline & $\begin{array}{c}\text { C SiC } \\
\text { silicon Carbide } \\
{[29-1127]} \\
\end{array}$ & $\begin{array}{c}\text { D SIC } \\
\text { Moissanite } \\
\text { [29-1128] }\end{array}$ & $\begin{array}{c}\text { SiC } \\
\text { Molssanite H } \\
\text { [29-1131] }\end{array}$ & $\begin{array}{c}\text { KAISIO, } \\
\text { Kalsilite } \\
\text { [11-0579] }\end{array}$ \\
\hline $\begin{array}{l}505 \text { Binder unused: } \\
\text { Candle \#1 (\#8) }\end{array}$ & \multirow[t]{3}{*}{$\boldsymbol{v}$} & \multirow[b]{3}{*}{$\boldsymbol{\sim}$} & \multirow{3}{*}{$\boldsymbol{\sim}$} & \multirow{3}{*}{$\checkmark$} \\
\hline Candle \#2 (\#9) & & & & \\
\hline Candle \#3 (\#11) & & & & \\
\hline $\begin{array}{l}505 \text { Binder, used: } \\
\text { Candle } \# 1 \text { ( } * 14)\end{array}$ & & & \multirow{3}{*}{$\begin{array}{c}\nu \\
v \\
v\end{array}$} & \multirow[b]{3}{*}{$\boldsymbol{\sim}$} \\
\hline Candle \#2 (-3\#11) & & & & \\
\hline Candle \#3 (-6 \#7) & & & & \\
\hline $\begin{array}{l}\text { 442T Binder unused } \\
\text { Candle \#1 ( ) }\end{array}$ & \multirow{3}{*}{$\checkmark$} & & \multirow[t]{3}{*}{$\boldsymbol{v}$} & \multirow{3}{*}{$\begin{array}{c}\nu \\
\nu\end{array}$} \\
\hline Candle \#2 (A) & & & & \\
\hline Candle \#3 (B) & & & & \\
\hline $\begin{array}{l}\text { 442T binder, used: } \\
\text { Candle \#1 (-1 \#6) }\end{array}$ & & \multirow[b]{3}{*}{$\boldsymbol{\nu}$} & \multirow{3}{*}{$\checkmark$} & \multirow[b]{3}{*}{$\boldsymbol{v}$} \\
\hline Candle \#2 (-4 \#3) & & & & \\
\hline Candle \#3 (\#8) & & & & \\
\hline
\end{tabular}

Although the binder constitutes less than 10 percent of the entire candle weight, it is not easily separated from the silicon carbide grains in sufficient quantities for XRD analysis.

All of the used 442-T binder candles had a greater relative amorphous peak than the unused 442-T binder candles. This indicated that there was a greater amorphous fraction in the used 442-T binder candles than in the unused ones. It was not possible to make definite conclusions regarding the 505 binder candles.

SEMVDX Analysis - Figures 34 and 35 show the difference between the outer surfaces of the unused and used Refractron 50/5 with 505 binders. The unused surface is relatively clean compared to the ash-laden used surface. The general surface EDX analysis, shown in Table 10 for the 505 binder candie in Table 11 for the 442-T binder candle, indicated that the layer deposited on the outer surface of the candle consisted of calcium, iron, magnesium and sulfur. Most of the silicon and aluminum readings were probably from the original underlying candle material. 


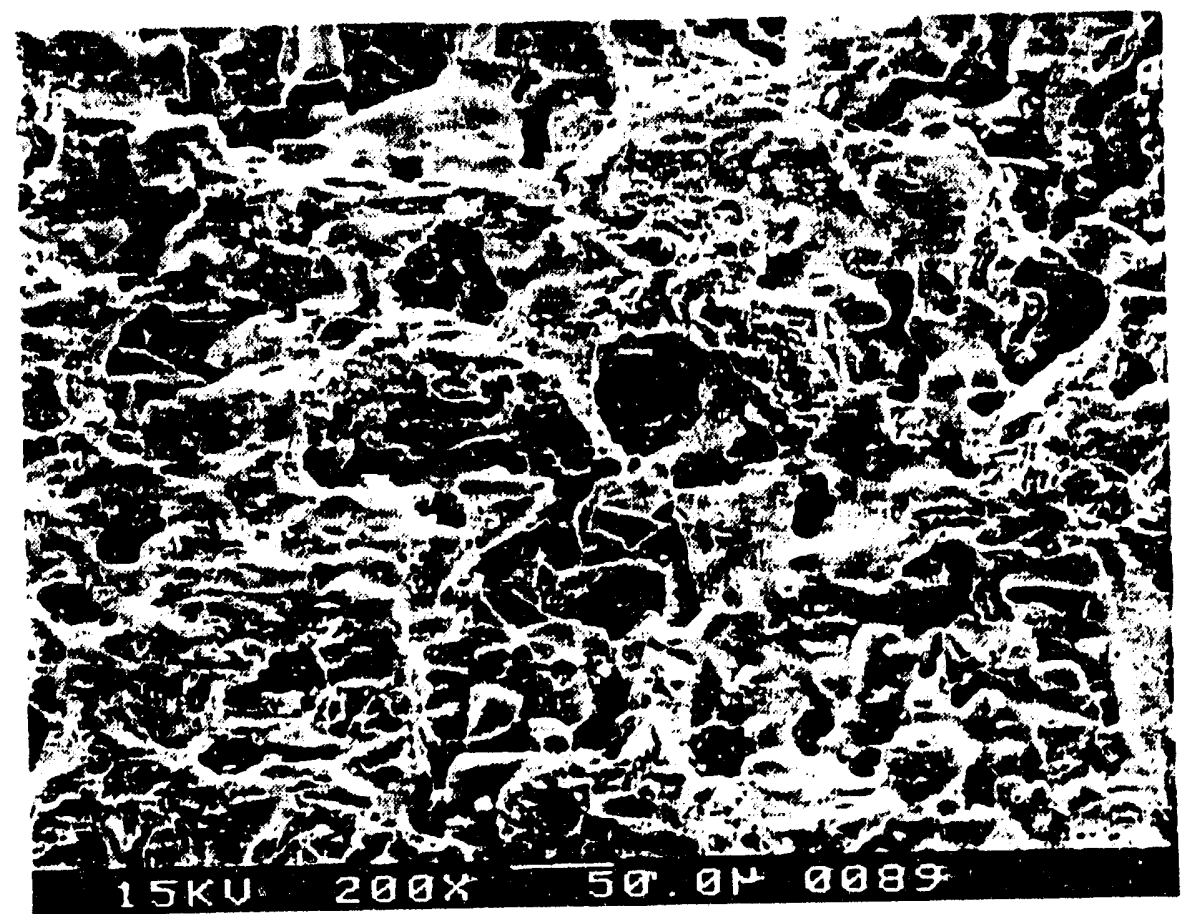

Figure 34. SEM Mlerograph, Unused Refractron 50/5, 505 Binder, Outer Surface, 200X

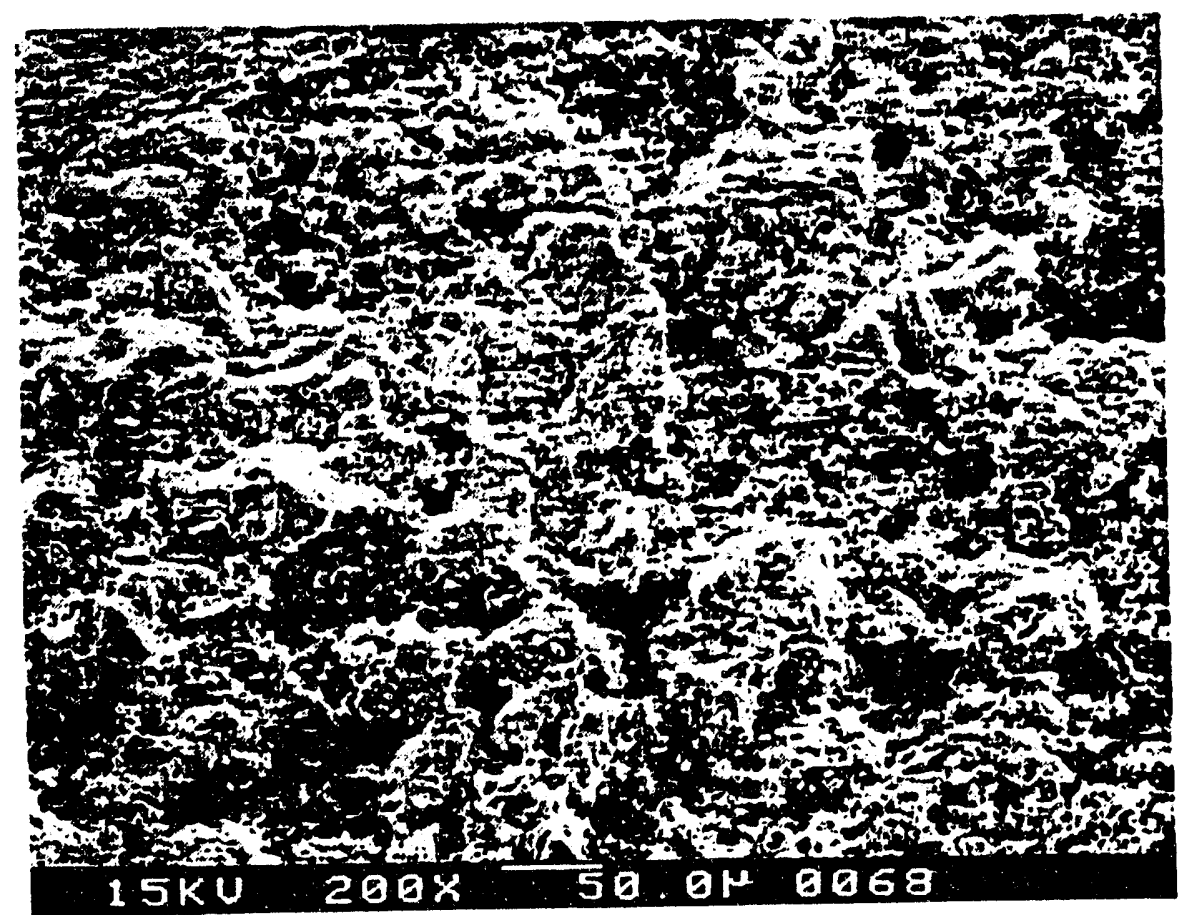

Figure 35. SEM Micrograph, Unused Retractron 50/5, 505 Binder, Outer Surface, $200 X$ 
Table 10. EDX Summary of General Surface Scans for Refractron 50/5 with 505 Binder

\begin{tabular}{|c|c|c|c|c|c|c|c|c|c|c|c|}
\hline & \multicolumn{10}{|c|}{ Elemental Wolght Porcentages } \\
\cline { 2 - 11 } & Al & S1 & Na & Fo & K & Ca & Mg & Cu & Sn & Cl & S \\
\hline Unused ("8) & & & & & & & & & & & \\
Outer surface & 8.5 & 80.0 & 0.7 & 3.5 & 2.4 & 2.6 & & & & 0.5 & 1.8 \\
X-section: outer layer & 5.0 & 87.9 & 0.4 & 2.5 & 1.3 & & & & 2.6 & & 0.4 \\
X-section: Inner layer & 7.8 & 82.8 & 1.1 & 2.7 & 2.5 & & & & 3.1 & & \\
\cline { 2 - 11 } & & & & & & & & & & & \\
Used Outer surface & 6.3 & 25.7 & & 24.0 & & 27.1 & 13.9 & & & & 3.0 \\
X-section: outer layer & 4.1 & 89.2 & 0.5 & & 3.7 & & 2.6 & & & & \\
X-section: inner layer & 6.8 & 88.7 & 0.5 & & 4.1 & & & & & & \\
\hline
\end{tabular}

Table 11. EDX Summary of General Surface Seans for Rofractron 50/5 with 442-T BInder'

\begin{tabular}{|c|c|c|c|c|c|c|c|c|c|c|c|}
\hline & \multicolumn{11}{|c|}{ Elemental Weight Percentages } \\
\hline & Al & SI & $\mathbf{N a}$ & Fe & $\mathbf{K}$ & Ca & Mg & Cu & Sn & Cl & $\mathbf{s}$ \\
\hline Unused (\#8) & & & & & & & & & & & \\
\hline Outer surface & $\begin{array}{l}6 . \\
4\end{array}$ & $\begin{array}{l}86 . \\
2\end{array}$ & 0.4 & 4.9 & 1.8 & & 0.1 & & & & 0.3 \\
\hline X-section: outer layer & $\begin{array}{l}5 . \\
2 .\end{array}$ & $\begin{array}{l}84 . \\
5\end{array}$ & 0.7 & 5.1 & 1.2 & 1.2 & & & & 0.8 & 1.2 \\
\hline X-section: inner layer & $\begin{array}{l}6 . \\
7\end{array}$ & $\begin{array}{l}88 . \\
9 .\end{array}$ & 0.6 & 1.9 & 1.6 & & & & & & 0.4 \\
\hline Used & & & & & & & & & & & \\
\hline Outer surface & $\begin{array}{l}6 . \\
6\end{array}$ & $\begin{array}{l}46 . \\
5\end{array}$ & & 6.1 & & $\begin{array}{l}23 . \\
2\end{array}$ & $\begin{array}{l}17 . \\
2\end{array}$ & & & & 0.4 \\
\hline X-section: outer layer & $\begin{array}{l}4 . \\
1\end{array}$ & $\begin{array}{l}80 . \\
7\end{array}$ & 0.4 & 5.2 & 2.6 & 3.3 & 0.0 & 2.3 & & & 1.5 \\
\hline X-section: inner layer & $\begin{array}{l}6 . \\
3\end{array}$ & $\begin{array}{l}86 . \\
6\end{array}$ & & & & 4.3 & & & & & 2.9 \\
\hline
\end{tabular}

'does not include the proprietary binder stabilizer 
In Figure 36 ls shown a higher magnification of the used candle which shows the ash deposits on the canclle that were used for the EDX. The ash consisted mostly of iron, calcium and magnesium (excluding of course the aluminum and silicon).

The general surface EDX analyses of the outer and inner layers of the unused and used candles from a cross-sectional view showed minimal ash infiltration. The high levels of iron, calcium and magnesium detected on the outer surface of the used Refractron $50 / 5$ with 505 binder were either not present in the cross-sectional EDX scans, or present at <5 weight percent, implying that most of the exposure to the testing environment was confined to the outer surface. However, closer examination of the used candie, shown in Figure 36, revealed that a fine layer of ash was deposited on the interior pore walls. The thickness of the ash deposit and the binder are evident in this micrograph and are about $1 \mathrm{\mu m}$. The EDX analysis indicated that magnesium was the major element in this ash layer.

The appearance of the unused Refractron 442-T resembled the 505 binder, since they are similar in construction and presumably differ only in binder stabilizing agents. General EDX analyses showed no significant difference between the two types of candles.

The outer layer from the cross-sectional view of both 505 and 442-T binder candles are shown in Figures 38 and 39, respectively. The used 442-T binder candle did not have the layer of ash deposits on the inner pore walls that were observed with the 505 binder candle. This suggests that the 442-T binder is less chemically reactive to the exposure environment. This would also explain why the strength decreased less with the used 442-T binder candles compared to the used 505 binder candles.

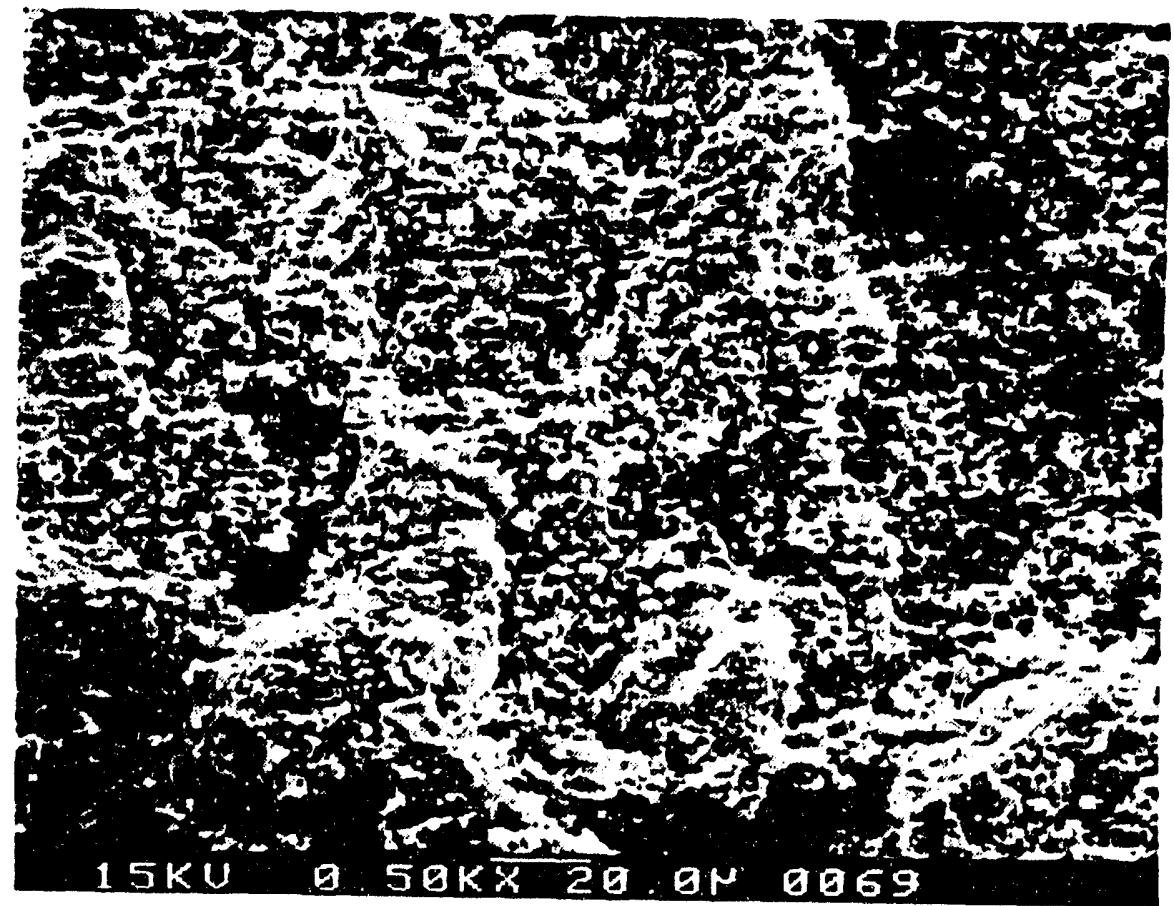

Figure 36. SEM Mlerograph of Unused Refractron 50/5, 505 Binder, Outer Surface, 500X 


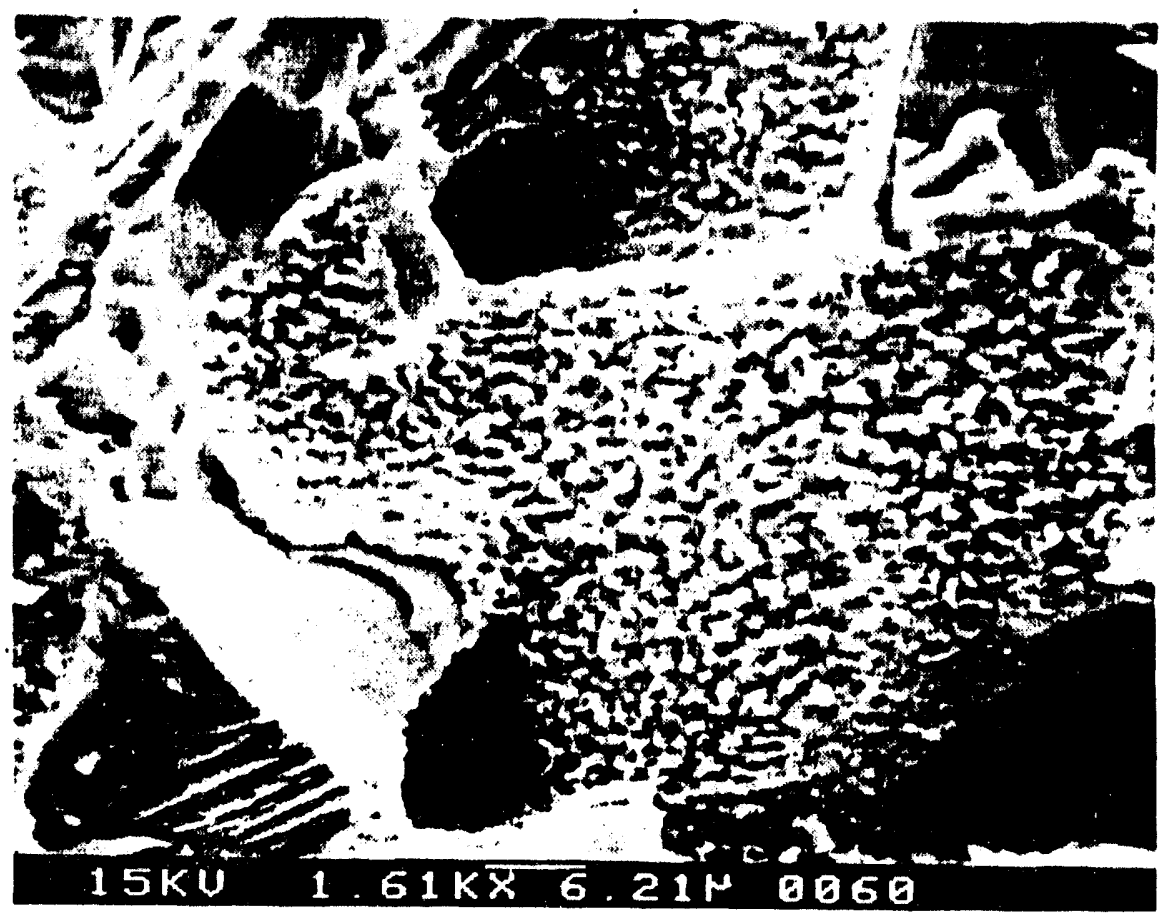

Figure 37. SEM Micrograph, Unused Refractron 50/5, 505 Binder, Outer Layer at 1610X

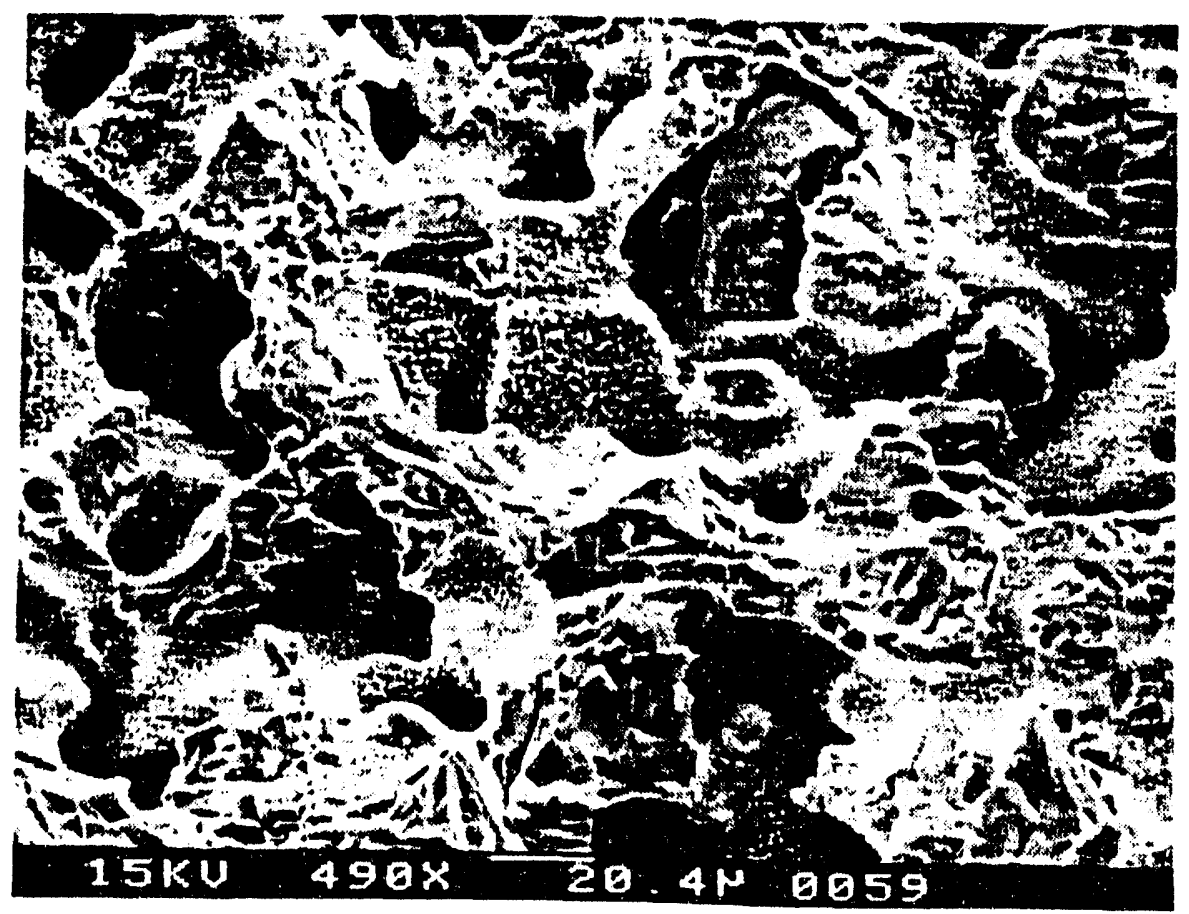

Figure 38. SEM Mlerograph of Exposed Refractron $50 / 5$ with 505 Binder at $490 \mathrm{X}$ 


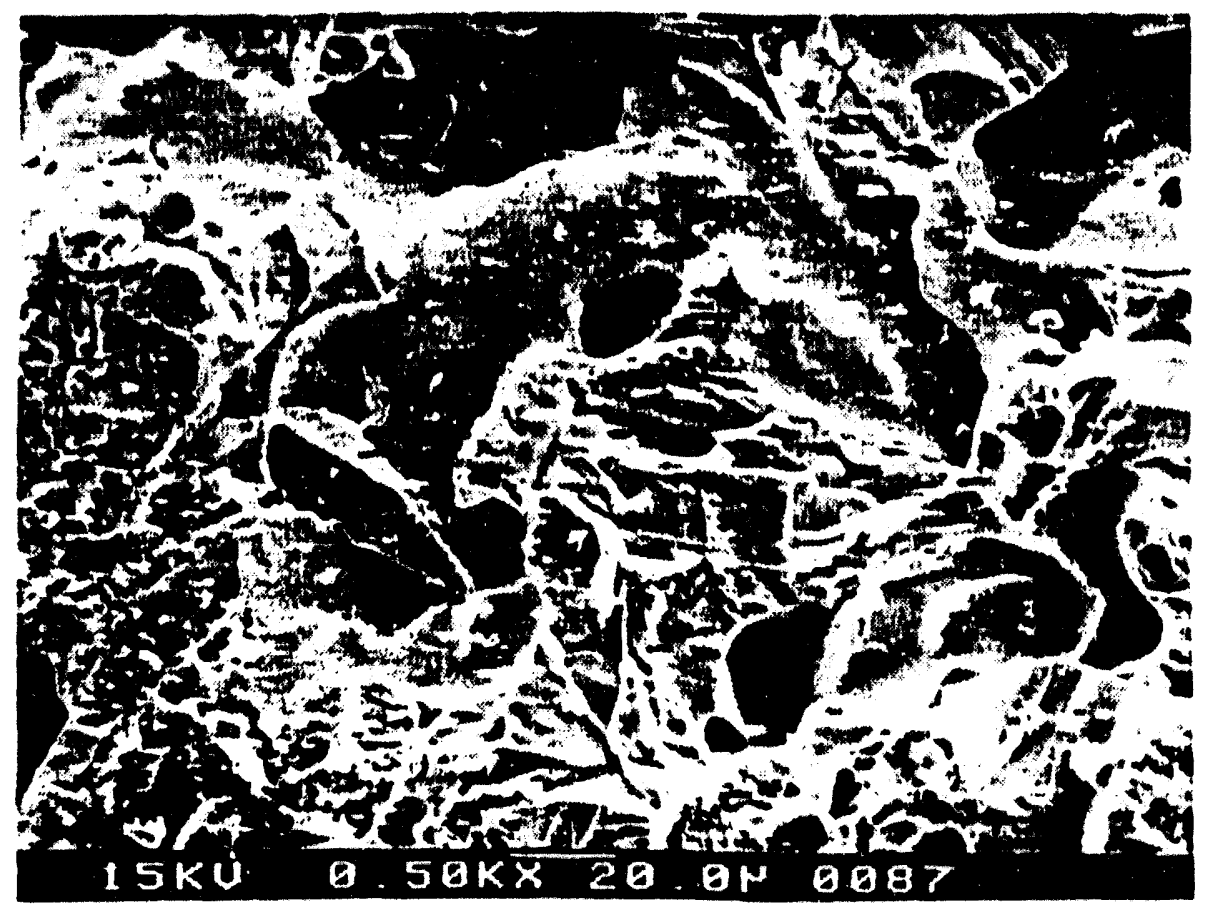

Flgure 39. SEM Mlorograph of Exposed Rofractron 50/5 with 442-T Binder at 500X

Conclusions - Based on the tests of the Refractron 50/5 candles, the following conclusions can be stated:

- There is a strength rectuction of about $35-40 \%$ due to exposure at room temperature for the $50 / 5$ with the 505 binder.

- There is a 55-65\% strength reduction at $980^{\circ} \mathrm{C}$ for the $50 / 5$ with the 505 binder.

- There is a 15-30 percent reduction in strength due to exposure at room temperature for the 50/5 with 442-T binder.

- There is a $25-50$ percent Increase in strength due to exposure at $980^{\circ} \mathrm{C}$. The increase in strength did not increase beyond the room temperature strengths of the unused candles.

- The high-temperature $\left(980^{\circ} \mathrm{C}\right)$ visco-plastic behavior of the candles increases candle toughness, compared to the brittle behavior exhibited at room temperature.

- Based upon XRD analysis, there was a greater amorphous fraction in the used Refractron 50/5 with 442-T binder candles than in the unused candle 3. The amorphous peaks of the 505 binder candles were inconclusive.

- General surface EDX analyses of the outer surfaces of the used candles indicated that the layer of ash deposited consisted primarily of $\mathrm{Ca}, \mathrm{Fe}$, and $\mathrm{Mg}$. 
In the fine layer of ash deposited on the inclde walls of the pores, as revealed in the crosesectional viow of a used Refractron 50/5 with 505 binder candle, the major element appeared to bo $\mathrm{Mg}$.

The used Rotrectron 50/5 with 442-T binder candles did not appear to have the layer of aah deposits on the inner walls of the pores, in the oroses-sectional viow, that the 505 bindere candles had.

The Rofractron 50/5 with 442-T binder candles appeared to withatand the environmental conditions of hot gas filtration better than the Rofractron $50 / 5$ with 505 binder candles. The 505 binder candles decreased in strength, whereas the 442-T binder candles increased in strength. The 442-T binder candles also seemed to be less chemically reactive to the environment. The visco-elastic behavior of the candles at high temperature appears to have an important role in the apparent increases in strength at high temperature of the used 442-T binder candles. Further investigation is required to understand the mechanisms resulting in the increased high-temperature maximum stress values.

It is especially important to note that the Schumacher Dla-Schumalith candle filtere suffered a conaiderable and unacceptable decrease in strength from exposure. The Fofractron filters did not. For this reason, the Refractron candle filters and their technological successors should bo considered for use in high pressure, high temperature systems. More data are needed, particularly at longer exposure times. Exposure times of hundreds, even thousands of hours are needed to fully test these materials in the DCFT environment.

\section{Fibroalca Candle Filters}

Industrial Filter and Pump began work on a candle filter made from a select blend of alumino-sillcate fibers and sillica and alumina binders. The candles are vacuum formed in a proprietary manufacturing process that results in a candle filter having a density of 0.15 percent of the sillicon carbide equivalent. The Fibrosics, therefore, are much lighter in weight which eases some high temperature design problems. For instance, their low thermal mass makes them less prone to thermal shock. The flange area and the closed end of the candle are formed simultaneously with the cylindrical section of the candle. Thus, there are no cement joints to worry about. The low density of the material makes possible a ceramic tubesheet of the same material.

Unfortunately, no testing in the IBSTF of Fibrosics was possible. Some testing was performed in the Hot End Simulation Rig. The results were very encouraging, even though only preliminary work was performed. No Fibrosics failed in service in the Hot End Simulation Rig.

The Hot End Simulation Rig, described in complete detail in another report (Ref. Galica, 1993), was designed to perform long duration material exposure tests on a very small scale, thus keeping the testing economic. This made it completely impossible, because of the low flow rates involved, to design a slagging impact separator or to inject ash into the secondary combustor. Thus, the ash contacting the filter in this rig was extremely sticky and was comprised solely of coal-bome mineral constituents. With no sorbent injected into the system, the sulfur content would have been significant as well. Therefore, no conclusions could be drawn as to the efficacy of a candle in the DCFT system from test results from the Hot End Rig. Nevertheless, some data were generated that did demonstrate the promise of the Fibrosic candle.

All candles used in the Hot End Rig suffered from a very sticky ash clinging to the outside of the candle. In addition to the Fibrosic candle, both Schumacher Dia-Schumalith and Industrial Filter and Pump candles were used. The Fibrosic candle exhibited the expected behavior of a candle, l.e., a sawtoothed differential pressure cycle as ash accumulated on the candle in between purge cycles. 
These cyoles are shown in Figures 40 and 41 for one of the runs. In the later hours of the run, It can be esen that the everage differentil preasure scross the candlo increased as more and more stloky aah could not be removed from the candle. This problem was nover seen in the IBSTF aince the PRIS was completely effective in removing the coal-bome ash.

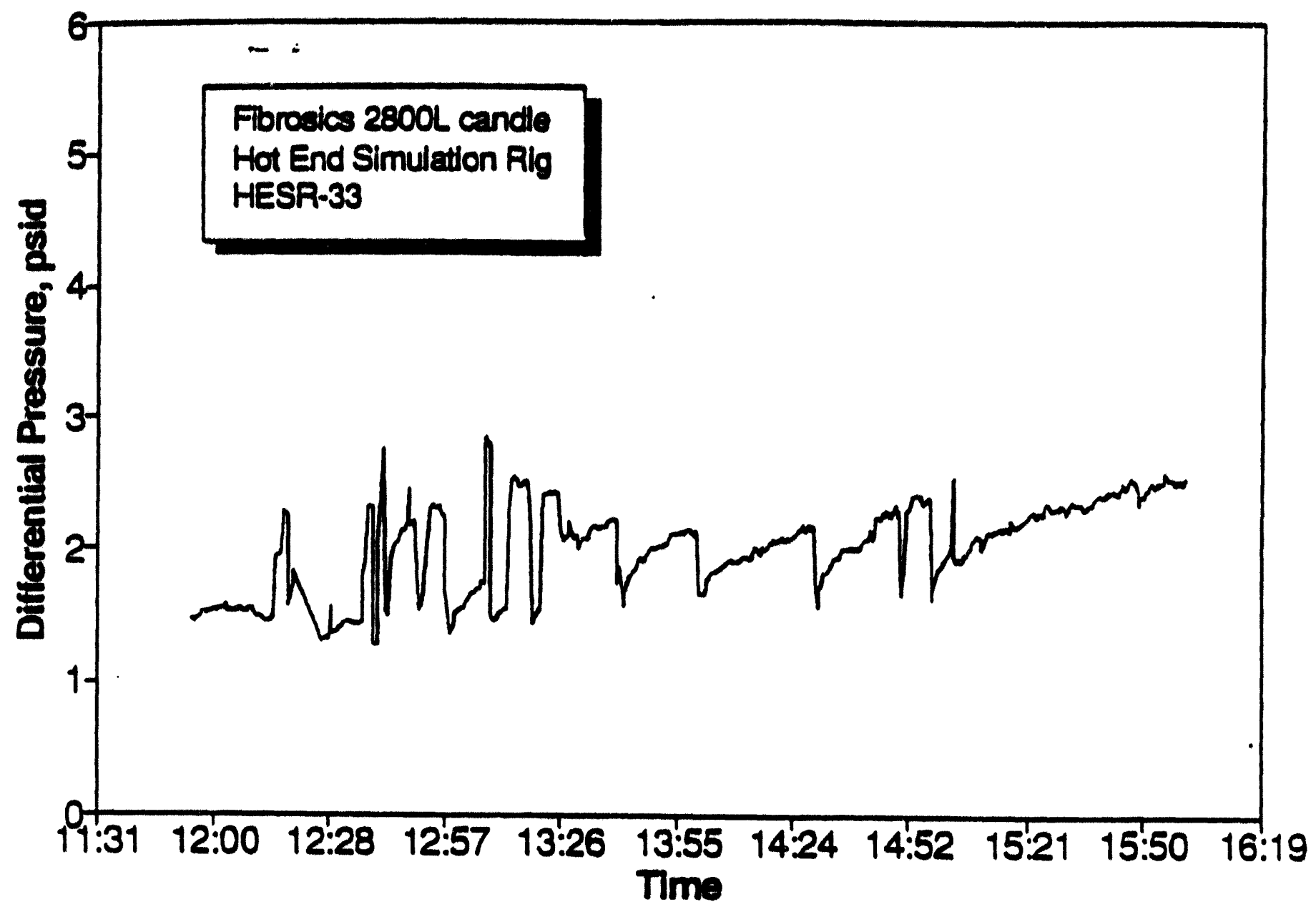

Figure 40. Differential Presaure Datn for Flbrosles Candle In the Hot End RIg, hours \&-10. 


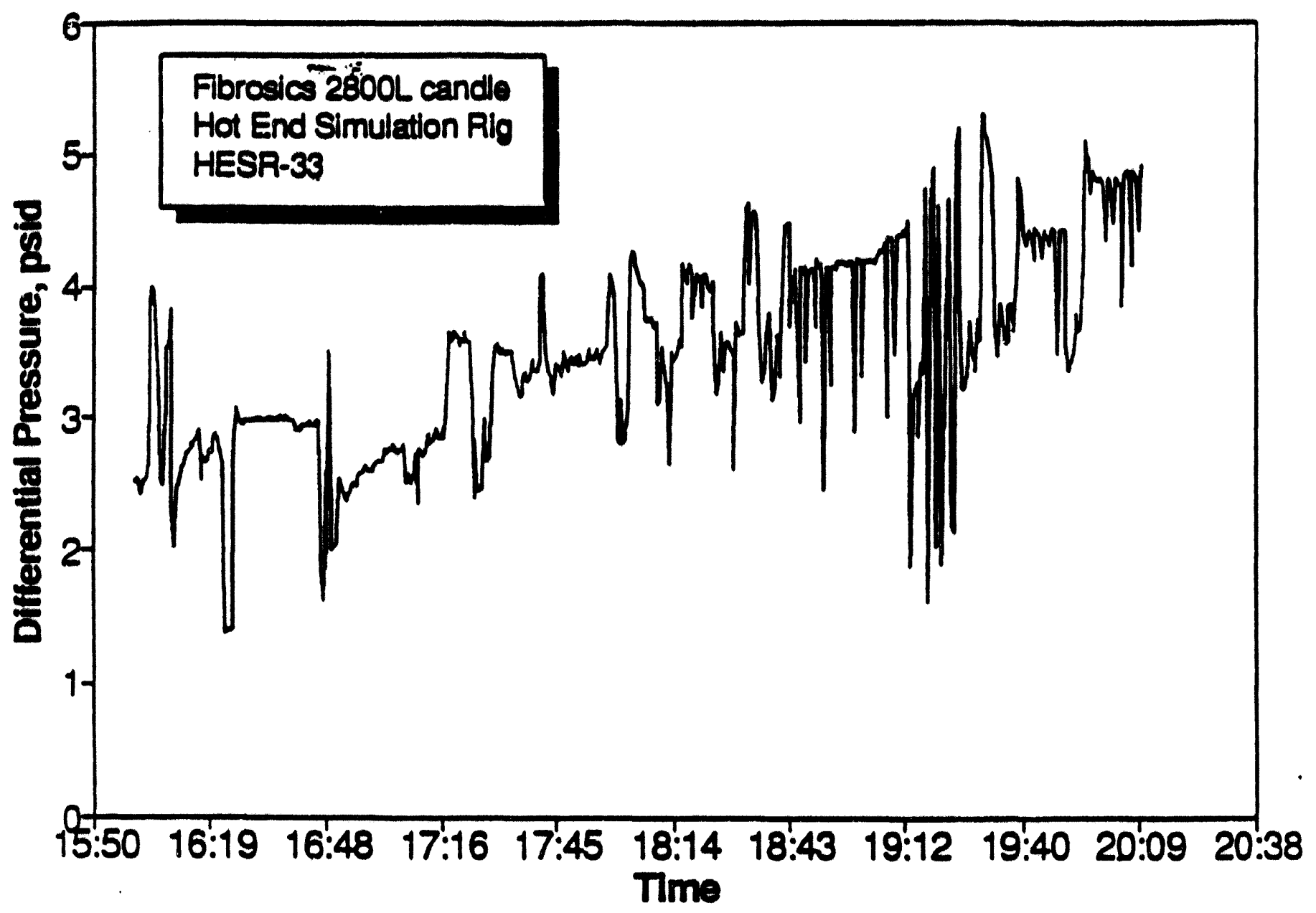

Figure 41. Difforential Pressure Data for Fibrosics Candle in the Hot End Rig, houre 10-14.

\section{LEAN PRIS EVALUATION}

The economic and technical feasibility of using candle filters was by no means assured. For this reason, other technologies were considered as backups. Bocause of the success of the richzOne, slagging PRIS, a lean-zone PRIS was investigated as an alternate to a barrier filter dovice. Initial investigations were paper studies along with testing recommendations. The concept included addition of a glase-like material to make the ash sticky enough to adhere to the rods of an impact separator. The initial studies included an analysis of the operating conditions, and factors that affected the selection of additives. Subsequent studies included concepts to remove deposits. Dr. Arthur Metcalfe of Metcalfe and Associates, Inc., was employed as a consultant for this work.

An initial analysis of the operating conditions showed that 2.5 times more material needed to be captured if dolomite was used rather than hydrated lime. This indicated that if all things were equal, hydrated lime would be preferable. There were unresolved feeding problems with hydrated lime, however, and the particulate size distribution of hydrated lime was finer than dolomite, requiring removal of smaller particulate even though the total amount to removed was less. 
The sorbent selected was a ortical paramoter. Frat of all, the quantity of partloulate varied by a factor of flve based on experimental data. These data are shown in Table 12. Approximately 21 pounds of dolomite were required for $100 \mathrm{lbs}$ of coal whereas with hydrated lime, only $4.1 \mathrm{lbs}$ were required. The extra mass attendant to using dolomite had some disadvantages. For instance, an additiorial 2500 Btw/100-16 dry coal was required to bring the added mass to 1900\%F. The heat of diesociation of the extra waight of carbonate, the work to dive the extra reactant into the pressurized system reduced the 4 cant edvantage of dolomite to a negligible amount. There was an added cost to diapose of additional material. Furthermore, a $99.6 \%$ collectlon efficienoy was required when using dolomite to give an identleal downstream concentration to a hydrated lime case with $\mathbf{9 9 . 0 \%}$ collection efficienoy.

Tablo 12. Addition of Sorbente Por $100 \mathrm{lbs}$ of Coal to Desulfurtze to 75 ppmw $8 \mathrm{~S}_{2}$

\begin{tabular}{|c|c|c|c|c|}
\hline Sorbent & \% Ca-apeoles & \%ca & $\begin{array}{l}\text { Ratio Cars } \\
\text { Required }\end{array}$ & $\begin{array}{l}\text { Wolght/100 ibs } \\
\text { Coal Regulred }\end{array}$ \\
\hline Dolomite & $57.2 \% \mathrm{CaCO}_{3}$ & 22.9 & 3.4 & 20.8 \\
\hline PHDL & $66 \% \mathrm{Ca}(\mathrm{OH})_{2}$ & 29.7 & 2.4 & 11.3 \\
\hline HL & $95 \% \mathrm{Ca}(\mathrm{OH})_{2}$ & 51.4 & 1.5 & 4.1 \\
\hline
\end{tabular}

Apparently, the nature of the particulates was less tractable to treatment by additives when dolomite was used. A review of Phase Dlagrams for Ceramists showed no desirable addittves that reduced the melting point of $\mathrm{MgO}$ from $5070^{\circ} \mathrm{F}$ to below $1900^{\circ} \mathrm{F}$. The large excess of dolomite that was added, as conversions were lower, ensures more unreacted $\mathrm{CaO}$ would be present; The high melting point of $\mathrm{CaO}\left(-4600^{\circ} \mathrm{F}\right)$ and the lack of strong melting point depressants for $\mathrm{CaO}$ was an additional factor againat the use of dolomite.

A summary of reactants and products from using dolomite and hydrated lime appears in Table 13. The three principal products are unused $\mathrm{CaO}$, unused $\mathrm{MgO}$ and $\mathrm{CaSO}_{\text {. }}$. The highest melting material is $\mathrm{MgO}\left(5070^{\circ} \mathrm{F}\right)$ and it appears only in dolomite. Calcium oxide melts at $4600^{\circ} \mathrm{F}$ whereas calcium sulfate melts at $2640^{\circ} \mathrm{F}$. 
Table 13. Reactants and Producte from Dolomite and Hydrated Llme (per 100 lbe dry coal).

\begin{tabular}{|l|l|l|l|}
\hline \multicolumn{5}{|l|}{ HYDRATED LIME } \\
\hline Reactants & Products \\
\hline Hydrated lime & $4.1 \mathrm{lbs}$ & CaSO & $5.95 \mathrm{lbs}$ \\
\hline Sulfur & $1.4 \mathrm{lbs}$ & Residual HL & $0.64 \mathrm{lbs}$ \\
\hline Oxygen & $2.1 \mathrm{lbs}$ & (less water) & \\
\hline Total & $7.6 \mathrm{lbs}$ & Net Products & $6.6 \mathrm{lbs}$ \\
\hline Lose (water) & $1.0 \mathrm{lbs}$ & & \\
\hline Net Reactants & $6.6 \mathrm{lbs}$ & & \\
\hline & & DOLOWITE & \\
\hline Reactante & & Products & \\
\hline Dolomite & $20.8 \mathrm{lbs}$ & CaSO, & $5.95 \mathrm{lbs}$ \\
\hline Sulfur & $1.4 \mathrm{lbs}$ & Unused CaO & $4.21 \mathrm{lbs}$ \\
\hline Oxygen & $2.1 \mathrm{lbs}$ & MgO & $4.22 \mathrm{lbs}$ \\
\hline Total & $24.3 \mathrm{lbs}$ & Net Products & $14.38 \mathrm{lbs}$ \\
\hline Loss (CO, & $9.87 \mathrm{lbs}$ & & \\
\hline Net Reactants & $14.43 \mathrm{lbs}$ & & \\
\hline
\end{tabular}

Six approaches to improve lean PRIS capture at $1900^{\circ} \mathrm{F}$ were proposed. These approaches are the melt or fluid approach, the sticky particle approach, the co-deposition approach, the plastic particle approach, the sticky impactor approach, and the molten impactor approach.

In the mett or fluid approach, the lean PRIS would act in the same way as the rich PRIS form which the slag flow in a molten stream. In the sticky particle approach, material is added in sufficient quantity to react with each of the particles to make it "sticky". Each major group of particles would require a different reactant to make it sticky, unless complete reaction and homogenization occurs. Therefore, it is more likely that the additive will provide the same coating on each type of particle. In the co-deposition approach, an inherently sticky substance is added that would be co-deposited on the impact surface. No particle-to-particle reaction or coating within the gas stream would be necessary but once the co-deposit has been made, reaction could occur at that time. In the plastic particle approach, each particle is made plastic 80 that capture can be achieved by plastic flow at impact in the lean PRIS. This concept may or may not need additives. In the sticky impactor approach, and additive is used to coat the rods in the PRIS to achieve adherence. In the molten impactor approach, the impact surface is in actual fact, a viscous melt to ensure sticking.

In the melt or fluid approach, it is necessary to consider the type of sorbent used, since the viscosity of it differe considerably. The basic approach to modily ash viscosities are to consult the well-known Reid-Cohen correlations. These correlations show ash viscosities as a function of sillica ratio, hence 
compositton, and temperature. Thus, one could theoretically adjust the species that affect aillca ratio $\left(\mathrm{SiO}_{2}, \mathrm{Fe}_{2} \mathrm{O}_{3}, \mathrm{CaO}\right.$, and $\left.\mathrm{MgO}\right)$ and obtain a specified viscosity at a given temperature. The allica ratio of slag from the ich PRIS is about 0.53 . At $2700^{\circ} \mathrm{F}$, such a slag would have a viscosity of 10 polse. This is consistent with the behavior of the rich PAIS. The silica ratio of hydrated lime with entrained slag (slag not captured by the lean PAIS) is estimated to be 0.19 , which is much too low to form a glass. The addition of $0.48 \mathrm{lbs}$ of sillca to $0.88 \mathrm{lbs}$ of unreacted hydrated lime and $0.65 \mathrm{lbs}$ of slag, would raise the sillca ratio to $0.4 ;$ this 18 safely within the glass forming range. To raise the sillca ratio to 0.4 for dolomite sorbent, would require addition of $5.75 \mathrm{lbs}$ of sillica to give $15.1 \mathrm{lbs}$ of modified slag. The viscosity would be 50 poise at $1900^{\circ} \mathrm{F}$, if all the constituents are melted and homogenized.

Several technical problems would need to be addressed with this approach. They include:

- Can reaction between added silica, unused sorbent, and entrained slag be completed in the 200 msecs dwell time to give the homogeneous melt that is required to obtain the minimum viscosity?

- If such a melt can be formed, will it be capable of carrying $5.63 \mathrm{lbs}$ of CaSO, in 2.01 lbs of melt (hydrated lime) or in $15.1 \mathrm{lbs}$ of melt (dolomite)?

One possibility that might be considered is to remove some of the calcium sulfate by an impact separation stef prior to making the silica addition to promote melt formation. This would only be possible with hydrated lime because the nature of the cake on the candle filters when dolomite is used indicates this would probably not be adherent in an impact separator.

A "sticky" particle would be expected to have a viscosity of less than $10^{7.6}$ poise. A removal method other than gravity flow used in the rich PRIS would need to be devised. Reaction between the additive, unused sorbent, entrained slag, and possibly with the calcium sulfate, will require to be uniform to generate particles with uniform compositions and similar degrees of stickiness. This is quite remote. A second possibility is to "coat" the particles and to assume that any subsequent reaction between the particle and its coating would be small in the maximum available time of 200 msec.

In the co-deposition approach, an additive is chosen that is itself sticky. Thus, it does not require reaction with other species. This is similar in nature to the "sticky impactor" approach and is discussed more fully in conjunction with that approach.

In the plastic particle approach, many of the particulates to be trapped are ionic solids, such as $\mathrm{CaO}$, $\mathrm{MgO}$, and $\mathrm{CaSO}_{4}$. Ionic crystals become plastic at a temperature above $0.5 \mathrm{~T}_{M}$ where $\mathrm{T}_{M}$ is the melting point in absolute temperature units. $T_{M}$ values for a few selected compounds are shown in Table 14. These are the temperatures for the onset of ductility. Two oxides, $\mathrm{CaO}$ and $\mathrm{MgO}$ are likely to behave as brittle, elastic solids at $1900^{\circ} \mathrm{F}$ whereas $\mathrm{CaSO}$, may be somewhat plastic. Calcium sulfate behaves plastically in the $1000-1500^{\circ} \mathrm{F}$ range.

If the melting points of $\mathrm{MgO}$ and $\mathrm{CaO}$ were reduced below $4000^{\circ} \mathrm{F}\left(0.5 \mathrm{~T}_{M}=1770^{\circ} \mathrm{F}\right)$ by reaction with additives, then plastic behavior of these new solids might be sufficiently plastic to adhere to the impact surface in the lean PRIS. However, the problem becomes one of ensuring enough reaction with all of the particles to form the new solids. 
Table 14. Melting Points and Values of $0.5 \mathrm{~T}_{m}$ for Selected lonle Sollds

\begin{tabular}{|lll|}
\hline \multicolumn{1}{|c|}{ Compostion } & Meling Point, ${ }^{\circ} \mathbf{F}$ & $0.5 T_{\mu}{ }^{\circ} \mathbf{F}$ \\
\hline $\mathrm{MgO}$ & 5070 & 2305 \\
$\mathrm{CaO}$ & 4600 & 2071 \\
$\mathrm{CaSO} 4$ & 2640 & 1091 \\
$\mathrm{NaCl}$ & 1474 & 507 \\
\hline
\end{tabular}

In the sticky impactor approach, impact surfaces would be maintained in a sticky condition by application of a low melting pointhow viscosity fluid. The composition could be one of those given in Table 15. The rate of application required can be estimated by assuming that the particles are all of equal size, spherical, and form a close-packed array. In this situation, the interstices constitute $35 \%$ by volume of the particles. For a first simplified calculation, we can assume the densities of the two particles are equal and then the deposit on the impact surface for the two sorbents will be as follows:

Table 15. Quantities of Materials for Sticky Impactor

\begin{tabular}{|cc|}
\hline \multicolumn{2}{|c|}{ Sorbent } \\
\hline Dolomite & Hydrated Lime \\
\hline $5.36 \mathrm{lbs}$ CaSO & 5.36 lbs CaSO \\
$4.45 \mathrm{lbs}$ unused $\mathrm{CaO}$ & $0.88 \mathrm{lbs}$ unreacted CaO \\
4.22 lbs MgO & $0.65 \mathrm{lbs}$ entrained slag \\
$0.65 \mathrm{lbs}$ entrained slag & $2.41 \mathrm{lbs}$ sticky binder \\
5.14 lbs sticky binder & \\
\hline 19.82 lbs total & 9.30 lbs total \\
\hline
\end{tabular}

If calcium sulfate is assumed self-sticking, then the sticky binder will be needed for the entrained slag and unreacted calcium oxide. This lowers the required sticky binder to $3.26 \mathrm{lbs}$ for the dolomite case and to $0.54 \mathrm{lbs}$ for the hydrated lime case. The method of application of the "sticky" binder might be via the co-deposition approach or by some other application method.

In the molten impactor concept, particles would impact on a molten surface that would transport the particles away by flow with possible purification arid recycle of the molten material. The molten surface would need to have adequate viscosity to withstand the aerodynamic drag. The most likely candidate for the molten material is a viscous silica-based glass. Potential problems might include the necessity for constant additions of silica to keep the silica ratio at the desired level.

Also, the working range at $1900^{\circ} \mathrm{F}$ of silica glasses is small. Additions of viscosity-reducing glass formers such as $\mathrm{B}_{2} \mathrm{O}_{5}$ and $\mathrm{CaF}_{2}$ would be essential. Also, the lean PRIS woould require considerable 
monitoring to control the melt as the composition of the siurry changes, and as the load on the turbine varies.

\section{SUMMARY}

High pressure, high temperature filtration of gas upstream of the turbine inlet is absolutely necessary to prevent turbine damage in a DCFT system. It is also necessary to meet clean air requirements which have become increasingly more stringent for particulate emissions. To meet both of these requirements, ceramic barrier filters were tested using subscale systems. While none of the tested systems proved commercially satisfactory, progress was made that indicated future versions of candle filters might be available in the near term which might prove viable in a DCFT system. Further developement work is indicated, both in the development of new candle and binder formulations and in extended exposure tests that are conducted under actual DCFT conditions.

\section{REFERENCES}

Chan, M. and J. Sawyer, 1993, Evaluation of Refractron Candles Exposed in the Solar Turbines Direct Coal-Fired Turbine Test Facility, Acurex Environmental Final Report FR-93-117.

LeCren, R.T., L.H Cowell, M.A. Galica, M. D. Stephenson and C.S. Wen, 1990, Advanced CoalFueled Industrial Cogeneration Gas Turbine System, Solar Turbines Annual Report to the Dept. of Energy.

Galica, M.A., 1993, Hot End Simulation Rig Topical Report, Topical report to the U.S. Dept. of Energy, Feb. 2, 1994. 

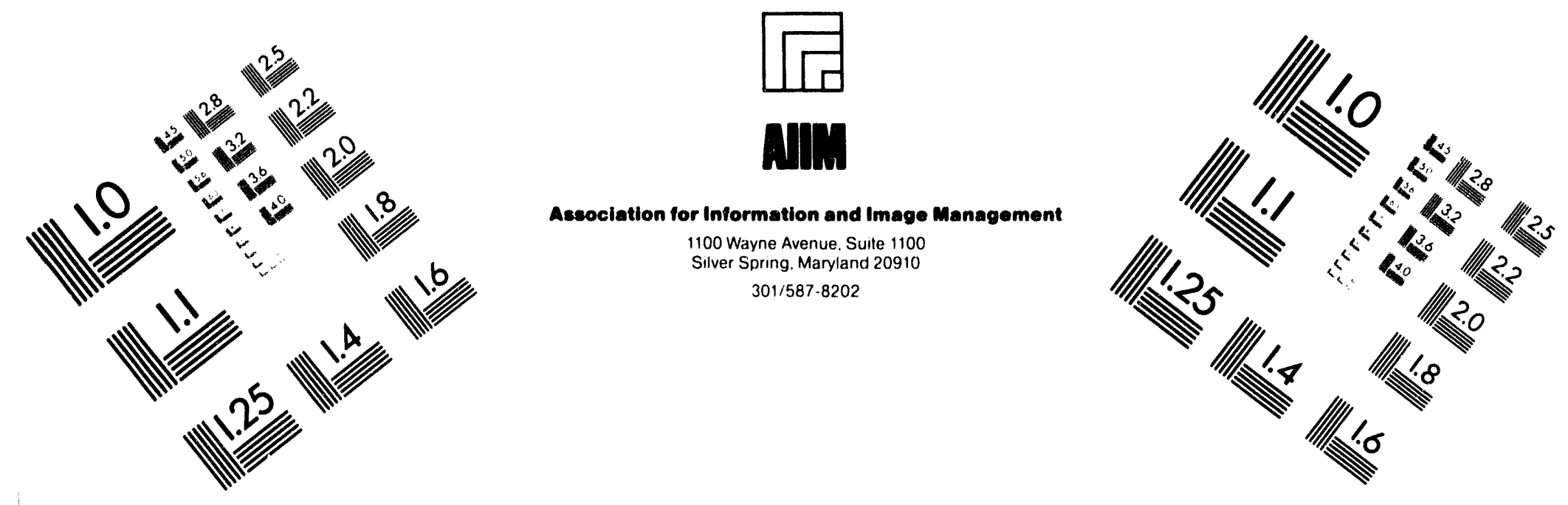

\section{Centimeter}

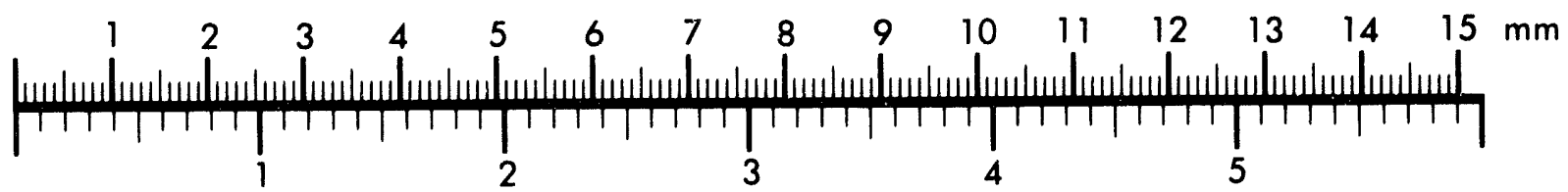
Inches
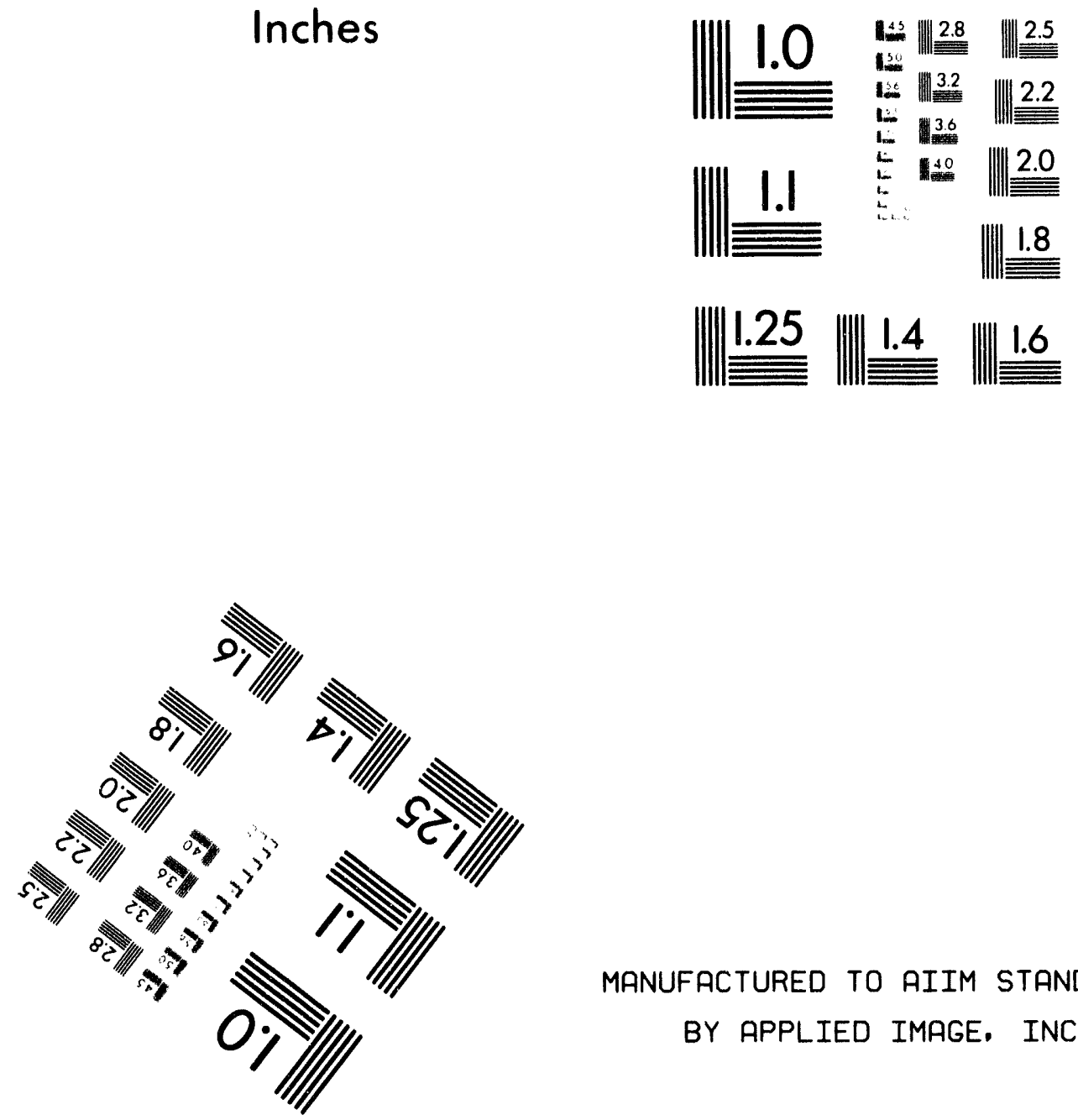

MANUFACTURED TO AIIM STANDARDS

BY APPLIED IMAGE. INC.

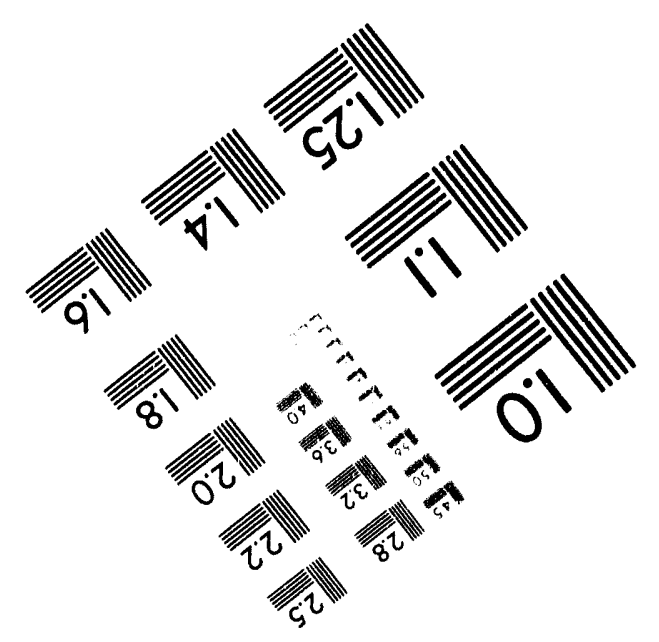




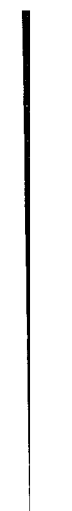



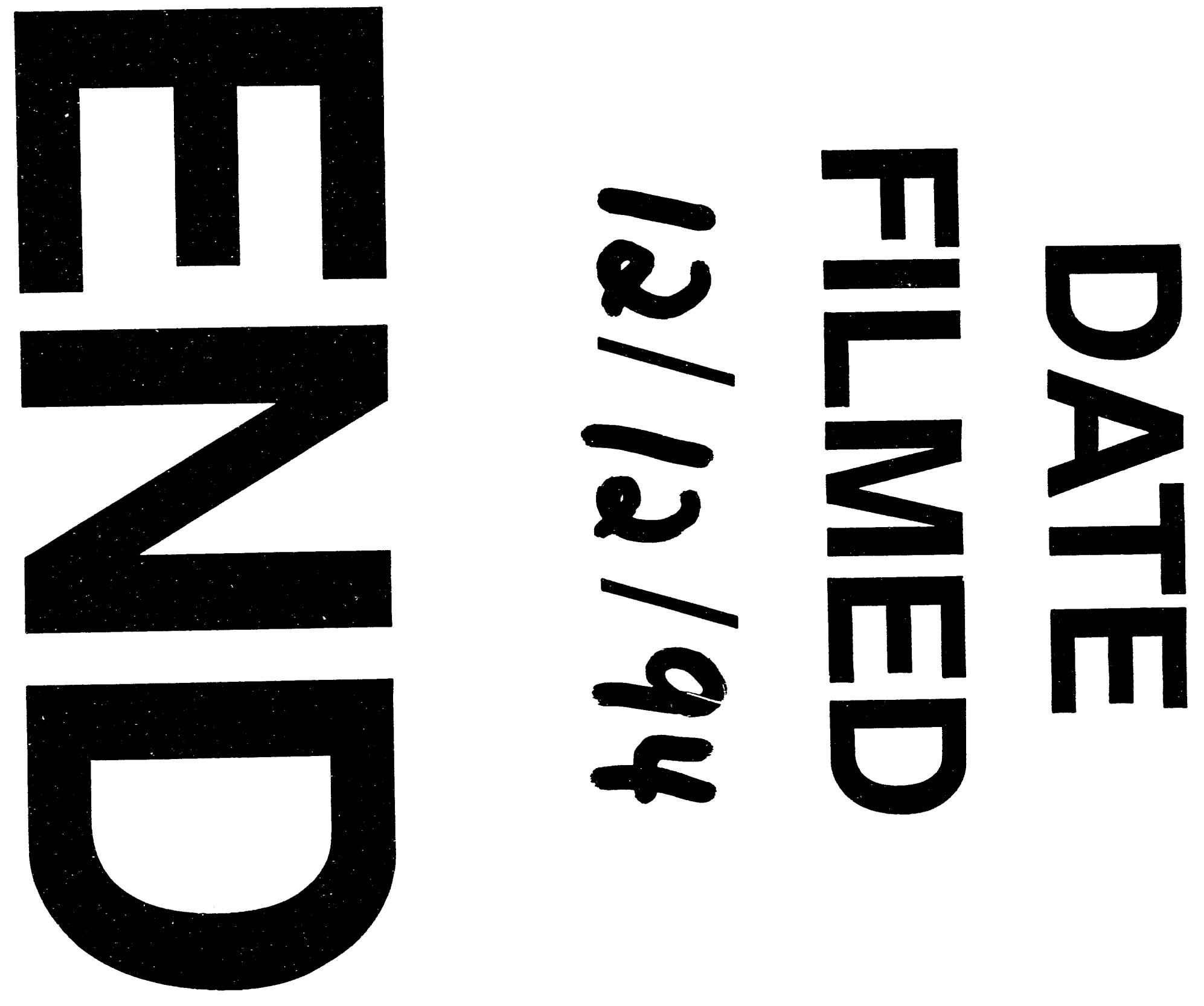